University at Buffalo School of Law

Digital Commons @ University at Buffalo School of Law

Journal Articles

Faculty Scholarship

$5-1-2021$

\title{
Disbanding Police Agencies
}

Anthony O'Rourke

University at Buffalo School of Law

Rick Su

UNC School of Law

Guyora Binder

University at Buffalo School of Law

Follow this and additional works at: https://digitalcommons.law.buffalo.edu/journal_articles

Part of the Law Enforcement and Corrections Commons, and the State and Local Government Law Commons

\section{Recommended Citation}

Anthony O'Rourke, Rick Su \& Guyora Binder, Disbanding Police Agencies, 121 Colum. L. Rev. 1327 (2021). Available at: https://digitalcommons.law.buffalo.edu/journal_articles/1012

This article originally appeared at 121 Colum. L. Rev. 1327 (2021). Reprinted by permission.

\section{C) ${ }_{\text {COPYRIGHT }}^{\text {N }}$}

This Article is brought to you for free and open access by the Faculty Scholarship at Digital Commons @ University at Buffalo School of Law. It has been accepted for inclusion in Journal Articles by an authorized administrator of Digital Commons @ University at Buffalo School of Law. For more information, please contact lawscholar@buffalo.edu. 


\title{
ESSAY
}

\section{DISBANDING POLICE AGENCIES}

\author{
Anthony O’Rourke, Rick Su** E Guyora Binder***
}

Since the killing of George Floyd, a national consensus has emerged that reforms are needed to prevent discriminatory and violent policing. Calls to defund and abolish the police have provoked pushback, but several cities are considering disbanding or reducing their police forces. This Essay assesses disbanding as a reform strategy from a democratic and institutionalist perspective. Should localities disband their police forces? One reason to do so is that discriminatory police departments are often too insulated from democratic oversight to be reformed. But can localities succeed in disbanding and replacing their forces with something better? Unfortunately, the structural entrenchment of sheriffs' offices and municipal police forces insulates them against such attacks as well. To challenge police power, localities may have to disband, and to disband, localities may have to alter the legal structure of state and local government. Reformers must use rare moments of mobilization like this one to overcome the misguided efforts of past reformers to lock in their victories. Successful reformers can best avoid repeating such mistakes by trusting in the democratic experiment and concentrating supervision of law enforcement at one level, the most local.

INTRODUCTION

I. WHY DISBAND POLICE FORCES? ............................................ 1337

A. Three Pathologies of Policing ......................................... 1337

B. Structural Obstacles to Police Reform ................................ 1343

1. Lack of Political Will.................................................... 1343

2. Police Unions......................................................... 1346

* Joseph W. Belluck \& Laura L. Aswad Professor, University at Buffalo School of Law.

** Professor, University of North Carolina School of Law.

*** SUNY Distinguished Professor \& Hodgson Russ Scholar, University at Buffalo School of Law. The authors wish to thank Richard Briffault, Barry Friedman, Jerry Frug, Aziz Huq, Noah Kazis, Darrell Miller, John Rappaport, Dan Richman, Jocelyn Simonson, and Chris Slobogin, as well as participants in workshops at the University at Buffalo School of Law, Hofstra Law School, the University of North Carolina School of Law, the Loyola Law School Policing Los Angeles Forum, and the 2020 State and Local Government Works-inProgress Conference at Willamette University College of Law. We are grateful to Michael Dolce, Maximo Larkin, Robert Sand, and Shakierah Smith for their excellent research assistance. We also wish to thank Josh Katz and the editorial staff of the Columbia Law Review for their outstanding work. 
3. Rank-and-File Culture 1348

4. Endogenous Policy Tradeoffs …….................................... 1350

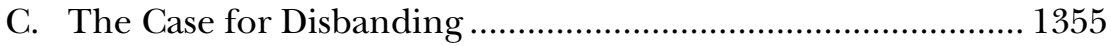

II. The LaW OF Restructuring Policing ........................................ 1359

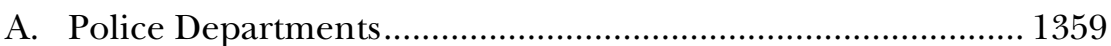

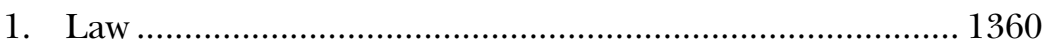

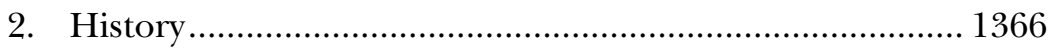

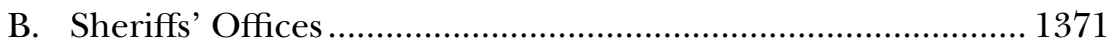

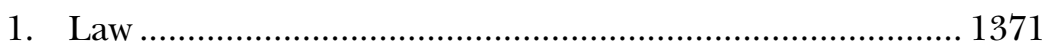

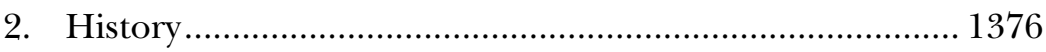

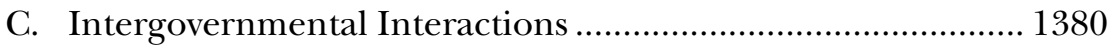

1. The Outsourcing of Municipal Services ........................... 1381

2. The Overlapping Jurisdiction of Police and Sheriffs ........ 1383

3. The Possible Expansion of the State Police ....................... 1386

III. LAW ENFORCEMENT EXCEPTIONALISM AND THE CHALLENGE

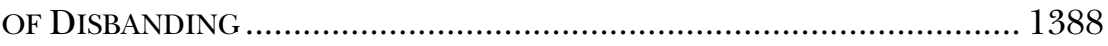

A. The Structural Problem: Law Enforcement Exceptionalism .. 1389

B. The Cause: Locking in Reform ............................................ 1396

C. A Lesson: Simplifying Police Governance.................................. 1398

D. The Structural Case for Local Control...................................... 1400

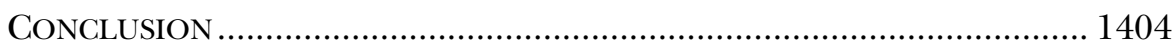

\section{INTRODUCTION}

Across the country, crowds braved the pandemic to demonstrate against racism and police violence, with the seeming support of every organization with a public relations department. ${ }^{1}$ Yet amid this consensus, ${ }^{2}$

1. See David Hessekiel, Companies Taking a Public Stand in the Wake of George Floyd's Death, Forbes (June 4, 2020), https://www.forbes.com/sites/davidhessekiel/2020 /06/04/companies-taking-a-public-stand-in-the-wake-of-george-floyds-death/?sh=7c135ec1 7214 [https://perma.cc/57JV-4R84]; Inti Pacheco \& Stephanie Stamm, What CEOs Said About George Floyd's Death, Wall St. J. (June 5, 2020), https://www.wsj.com/articles/whatexecutives-said-about-george-floyds-death-11591364538 (on file with the Columbia Law Review).

2. Polling during the summer of 2020 showed consensus support for changes in policing, including punishment (ninety-six percent) and exclusion (ninety-eight percent) of abusive officers, improving community relations (ninety-seven percent), more collaboration with community organizations (eighty-two percent), and "ending stop and frisk" (seventyfour percent). See Steve Crabtree, Most Americans Say Policing Needs 'Major Changes', Gallup (July 22, 2020), https://news.gallup.com/poll/315962/americans-say-policingneeds-major-changes.aspx [https://perma.cc/JR7K-MLGN]. In November, voters approved added police oversight measures in Berkeley, Oakland, San Francisco, San Jose, San Diego, and Sonoma County (CA); Portland (OR); Columbus and Akron (OH); Pittsburgh and Philadelphia (PA); Kyle (TX); and King County (WA). Madison Pauly \& Samantha 
demonstrators' calls to "abolish" or "defund" the police provoked controversy. ${ }^{3}$ These slogans expressed that discriminatory police violence is a policy, ${ }^{4}$ not a "split-second judgment []" ${ }^{5}$ or the work of "bad apples", ${ }^{6}$ that the war on crime diverted needed resources from the poor communities it preyed upon; $;^{7}$ and that a good society achieves safety by peaceful, participatory means. ${ }^{8}$ Conservative critics seized on these slogans as incendiary

Michaels, BLM Activists Demanded Police Accountability. In City After City, Voters Agreed., Mother Jones (Nov. 6, 2020), https://www.motherjones.com/crime-justice/2020/11/blmpolice-accountability-george-floyd-breonna-taylor-election-ballot-measures [https://perma. cc/G3ZP-S4T9].

3. In July polls, structural changes with significant—but partisan—support included "major changes" in policing (fifty-eight percent), eliminating police unions (fifty-six percent), eliminating "enforcement of nonviolent crimes" (fifty percent), and shifting funds from police to social programs (forty-seven percent). By contrast, few Americans supported "abolishing police departments" (fifteen percent), irrespective of racial group or partisan affiliation. See Crabtree, supra note 2.

4. See Paul Butler, Chokehold: Policing Black Men 2-3 (2017) (“[T]he police, as policy, treat African Americans with contempt.”); see also Michelle Alexander, The New Jim Crow: Mass Incarceration in the Age of Colorblindness 176 (10th anniversary ed., 2020) ("Police supervision, monitoring, and harassment are facts of life . . f for all those who 'look like' criminals. Lynch mobs may be long gone, but the threat of police violence is ever present."); Alex S. Vitale, The End of Policing 50-54 (2018) ("Today's modern police are not that far removed from their colonialist forebears. They too enforce a system of laws designed to reproduce and maintain economic inequality, usually along racialized lines.”).

5. Graham v. Connor, 490 U.S. 386, 397 (1989).

6. See Vitale, supra note 4, at 29; Alexi Jones \& Wendy Sawyer, Not Just "A Few Bad Apples": U.S. Police Kill Civilians at Much Higher Rates than Other Countries, Prison Pol'y Initiative (June 5, 2020), https://www.prisonpolicy.org/blog/2020/06/05/policekillings [https://perma.cc/CWW6-C7XG].

7. See Elizabeth Hinton, From the War on Poverty to the War on Crime: The Making of Mass Incarceration in America 1-2 (2016) ("Following the passage of the Law Enforcement Assistance Act, the federal government began to retreat from and eventually undercut many of the Great Society programs .... .); Loïc Wacquant, Punishing the Poor: The Neoliberal Government of Social Insecurity 41 (2009) (describing America's replacement of the "(semi)- welfare state by a police and penal state," which criminalized marginality); BAN Defund CPD Demands, Black Lives Matter Chi., https://www.blacklives matterchicago.com/ban-defund-cpd-demands [https://perma.cc/7JSA-JRUG] (last visited Jan. 12, 2021) (noting that "Chicago spends nearly $40 \%$ of its annual operating budget, over $\$ 1.8$ billion, on the Chicago Police Department" and calling for a reallocation of these funds to public services); What Defunding the Police Really Means, Black Lives Matter (July 6, 2020), https://blacklivesmatter.com/what-defunding-the-police-really-means (on file with the Columbia Law Review) ("[A]s long as we continue to pump money into our corrupt criminal justice system at the expense of housing, health, and education investments-we will never truly be safe.”). See generally John J. Donohue III \& Peter Siegelman, Allocating Resources Among Prisons and Social Programs in the Battle Against Crime, 27 J. Legal Stud. 1, 1-2 (1998) (examining, empirically, the marginal social costs and benefits of incarceration as compared to expenditures on social programs).

8. See Marianne Kaba, Opinion, Yes, We Mean Literally Abolish the Police, N.Y. Times (June 12, 2020), https://www.nytimes.com/2020/06/12/opinion/sunday/floydabolish-defund-police.html (on file with the Columbia Law Review) (advocating for a society "built on cooperation instead of individualism, on mutual aid instead of self-preservation"); Rachel Kushner, Is Prison Necessary? Ruth Wilson Gilmore Might Change Your Mind, N.Y. Times Mag. (Apr. 17, 2019), https://www.nytimes.com/2019/04/17/magazine/prison- 
threats to leave society defenseless against crime, ${ }^{9}$ while liberal centrists fretted that hyperbolic rhetoric would fracture a fragile consensus for reform and an electoral coalition poised to retake power. ${ }^{10}$ Yet the Minneapolis City Council proposed a referendum and city charter amendment to disband its police force and replace it with a new "Department of Community Safety and Violence Prevention."11 While Minneapolis's efforts have stalled, ${ }^{12}$ initiatives to substantially reduce police budgets continue to make headway in other cities. ${ }^{13}$

abolition-ruth-wilson-gilmore.html (on file with the Columbia Law Review) (describing the abolition movement and its emphasis on holistic and proactive approaches to investing in communities).

9. See Dartunorro Clark \& Caroline Vakil, Barr Claims Defunding Police Would Lead to 'Vigilantism' in Major American Cities, NBC News (June 8, 2020), https://www.nbcnews. $\mathrm{com} /$ politics/politics-news/barr-claims-defunding-police-would-lead-vigilantism-major-am erican-cities-n1227866 [https://perma.cc/VYN2-HSPA]; Julia Musto, Law Enforcement Experts on Defunding, Dismantling Police: 'When You Call 911 Who Is Going to Come Out?', Fox News (June 27, 2020), https://www.foxnews.com/media/law-enforcement-pan el-defund-police [https://perma.cc/ZX33-RZYG].

10. Fadel Allassan, James Clyburn: "Defund the Police" Slogan Could Hurt Black Lives Matter Movement, Axios (Nov. 8, 2020), https://www.axios.com/james-clyburn-defundpolice-black-matter-2900b5ff-a61 e-4ab8-89ff-26d73400d413.html [https://perma.cc/5SHGDZCG]; Sarah Ferris, Marianne Levine \& Heather Caygle, Hill Democrats Quash Liberal Push to 'Defund the Police', Politico (June 8, 2020), https://www.politico.com/news/2020 /06/08/defund-police-democrats-307766 [https://perma.cc/67PL-M5W2]; Amie Parnes, Jordain Carney \& Cristina Marcos, Biden, Democrats Seek to Shut Down Calls to Defund Police, Hill (June 9, 2020), https://thehill.com/homenews/campaign/501730-biden-dem ocrats-seek-to-shut-down-calls-to-defund-police [https://perma.cc/2658-5VK3].

11. Liz Navratil, Minneapolis City Council Votes Unanimously for Proposal that Could Replace Police Department, Star Trib. (June 27, 2020), http://strib.mn/2Zrc16z [https:// perma.cc/T69K-J6UM].

12. See infra note 27 and accompanying text.

13. See Wesley Lowery, The Most Ambitious Effort Yet to Reform Policing May Be Happening in Ithaca, New York, GQ (Feb. 22, 2021), https://www.gq.com/story/ithaca-mayorsvante-myrick-police-reform [https://perma.cc/K4LT-749V] (reporting that the mayor of Ithaca, NY proposes replacing the police department with "Department of Community Solutions and Public Safety"); Roge Karma, Los Angeles Voters Just Delivered a Huge Win for the Defund the Police Movement, Vox (Nov. 4, 2020), https://www.vox.com/2020/11/4/2 1549019/measure-j-police-abolition-defund-reform-black-lives-matter-protest-2020-electiongeorge-floyd (on file with the Columbia Law Review) (reporting the success of a ballot measure that will likely, in practice, "redirect[] [money] from police department budgets to ... alternative service providers"); Matt Markovich, Defunding Seattle Police: City Council OKs Sharp Cuts but Avoid 50\% Budget Reduction, KOMO News (Aug. 10, 2020), https://komonews.com/news/local/defunding-seattle-police-city-council-poised-to-cutdepartments-budget-today [https://perma.cc/C8VX-YD2C] (reporting that the Seattle City Council approved a spending plan that would reduce funding to its police department); Gabriela Milian, What Does Defund the Police Mean for Los Angeles, ABC 7 (July 2, 2020), https:/ /abc7.com/6293495/?ex_cid=TA_KABC_FB\&utm_campaign=trueAnthem\%3A+Tr ending+Content\&utm_medium=trueAnthem\&utm_source=facebook [https://perma.cc/ 6LSX-74P5] ("The Los Angeles City Council approved a \$150 million budget cut to the Los Angeles Police Department's budget ....”); Meena Venkataramanan, Austin City Council Cuts Police Department Budget by One-Third, Mainly Through Reorganizing Some Duties Out from Law Enforcement Oversight, Tex. Trib. (Aug. 13, 2020), https://www.texas 
This Essay offers a democratic perspective ${ }^{14}$ on dissolution of police agencies as neither utopian, nor anarchic, but as the kind of institutional experimentation $^{15}$ that should be routine in a properly functioning democracy. The existence, function, jurisdiction, and governance structure of police agencies are, after all, questions of institutional design, properly resolved by a democratic public. Consider first, the wide range of police functions and powers-combining investigation, security, custody, community caretaking, and emergency response. ${ }^{16}$ Police serve as agents of both judicial and executive branches of government and intervene in disputes and mental health crises. ${ }^{17}$ Should all of these functions be performed and prioritized by the same agency? Consider second, the enormous multiplicity and overlap of our 18,000 police jurisdictions,

tribune.org/2020/08/13/austin-city-council-cut-police-budget-defund [https://perma.cc/ R75H-VQTL] ("The Austin City Council unanimously voted to cut its police department budget by $\$ 150$ million ....").

14. This perspective is informed by a rapidly growing literature, including David Alan Sklansky, Democracy and the Police 5-6 (2008) (exploring "how our notions about the police and our strategies for police reform might change if they were rooted in a more explicit, and richer, set of ideas about democracy"); Barry Friedman \& Maria Ponomarenko, Democratic Policing, 90 N.Y.U. L. Rev. 1827, 1832 (2015) ("Rather than attempting to regulate policing primarily post hoc through episodic exclusion motions or the occasional action for money damages, policing policies and practices should be governed through transparent democratic processes such as legislative authorization and public rulemaking."); Sunita Patel, Toward Democratic Police Reform: A Vision for "Community Engagement” Provisions in DOJ Consent Decrees, 51 Wake Forest L. Rev. 793, 798 (2016) ("[M] arginalized communities and community stakeholders should have a direct role in the consent decree monitoring process."); Jocelyn Simonson, Police Reform Through a Power Lens, 130 Yale L.J. 778, 783 (2021) [hereinafter Simonson, Power Lens] ("[C]oncentrating on power arrangements and a particular form of contestatory democracy ... open [s] up police 'reforms' to new institutional arrangements ...."). While theorists have identified democracy with a variety of different values and institutional schemes, a wide range of such theories requires accountability of officials to constituents. See Bernard Manin, Adam Przeworski \& Susan C. Stokes, Introduction to Democracy, Accountability, and Representation 1, 1-26 (Adam Przeworski, Susan C. Stokes \& Bernard Manin eds., 1999) (noting that the claim "that democracy systematically causes governments to be representative ... is widespread"). See generally David Held, Models of Democracy (3d ed. 2006) (undertaking a comparative survey of democratic models). The democratic case for a popular power to disband police agencies rests on its value as an accountability mechanism.

15. See generally Archon Fung, Empowered Participation: Reinventing Urban Democracy (2004) (discussing participatory democracy as a strategy for police reform); Charles F. Sabel \& William H. Simon, Democratic Experimentalism, in Searching for Contemporary Legal Thought 477, 478 (Justin Desautels-Stein \& Christopher Tomlins eds., 2017) ("Democratic experimentalism aims ... to show . . that dominant understandings of law should be revised to make the most of their potential.").

16. See generally Barry Friedman, Disaggregating the Police Function, 169 U. Pa. L. Rev. (forthcoming 2021) (manuscript at 26-52), https://ssrn.com/abstract=3564469 (on file with the Columbia Law Review) [hereinafter Friedman, Disaggregating] (providing an overview of the activities in which police officers engage beyond strict law enforcement).

17. See id. (manuscript at 22-52); see also infra note 337 and accompanying text. 
employing almost 900,000 armed officers and 400,000 civilians. ${ }^{18}$ Is this arrangement of jurisdictional authority optimal? Is this enormous capacity for coercive force necessary? Consider third that it is axiomatic that in a democracy, use of force must be subject to democratic supervision. ${ }^{19}$ What institutional design would best achieve this democratic control?

18. Duren Banks, Joshua Hendrix, Matthew Hickman \& Tracey Kyckelhahn, DOJ, Bureau of Just. Stat., NCJ 249681, National Sources of Law Enforcement Employment Data 1 (2016), https://www.bjs.gov/content/pub/pdf/nsleed.pdf [https://perma.cc/4PCMF6HG] ("Law enforcement in the United States is made up of about 18,000 federal, state, and local agencies."); Mike Riggs, How a City with Two Dozen Law Enforcement Agencies Handles a Huge Crisis, Bloomberg CityLab (Sept. 25, 2013), https://www.bloomberg.com/ news/articles/2013-09-25/how-a-city-with-two-dozen-law-enforcement-agencies-handles-ahuge-crisis (on file with the Columbia Law Review) ("There are roughly 27 law enforcement agencies with overlapping jurisdiction in Washington, D.C.”). In 2016, 12,261 general purpose local police forces reported 468,274 sworn officers and 131,274 full-time civilian employees. Shelley S. Hyland \& Elizabeth Davis, DOJ, Bureau of Just. Stat., NCJ 252835, Local Police Departments, 2016: Personnel 2 tbl.2 (2019), https://www.bjs.gov/content/ pub/pdf/lpd16p.pdf [https://perma.cc/HKE8-8AF9]. Not all municipalities have their own police forces, and many people live in unincorporated areas. Darryl T. Cohen, Geoffrey W. Hatchard \& Steven G. Wilson, U.S. Census Bureau, Population Trends in Incorporated Places: 2000 to 2013, at 1-7 (2015), https://www.census.gov/content/dam/Census/library /publications/2015/demo/p25-1142.pdf [https://perma.cc/PFQ6-YAEM] (reporting that there were 19,508 incorporated municipalities in 2013, encompassing $62.7 \%$ of the U.S. population). Also, 3,012 general purpose sheriffs' offices reported 360,000 full-time employees, of which 173,000 were sworn officers. Connor Brooks, DOJ, Bureau of Just. Stat., NCJ 252834, Sheriffs' Offices, 2016: Personnel 1 (2019), https://www.bjs.gov/content/ pub/pdf/so16p.pdf [https://perma.cc/PFS2-B6VE]. Almost every county or county equivalent appears to have a sheriff. See id.; How Many Counties Are There in the United States?, U.S. Geological Surv. (Apr. 3, 2008), https://www.usgs.gov/media/audio/howmany-counties-are-there-united-states [https://perma.cc/V5ZV-TSKD] (stating that there are 3,007 counties in the United States). In 2008, there were 60,772 sworn and 32,376 unsworn state police officers and 60,432 sworn and 33,861 unsworn officers in specialpurpose state and local forces. Banks et. al, supra, at 5. In 2016, 132,000 federal law enforcement officers served in about eighty different forces-though the number of federal full-time civilian employees in law enforcement functions was undetermined. Connor Brooks, DOJ, Bureau of Just. Stat., NCJ 251922, Federal Law Enforcement Officers, 2016Statistical Tables 1-4 (2019), https://www.bjs.gov/content/pub/pdf/fleo16st.pdf [https:// perma.cc/XRH7-AAPM].

19. See Peter D. Feaver, Civil-Military Relations, 2 Ann. Rev. Pol. Sci. 211, 214-15 (1999) ("Democratic theory is summed in the epigram that the governed should govern .... It follows that, in a democracy,... [r] egardless of how strong the military is, civilians are supposed to remain the political masters.”); Friedman \& Ponomarenko, supra note 14, at 1831-32 ("Of all the agencies of executive government, those that 'police'-i.e., that ... employ force-are the most threatening to ... libert[y] ... [y]et ... the least regulated ... . It is ... unacceptable ... for policing to remain aloof from ... democratic processes ...."); Richard H. Kohn, How Democracies Control the Military, 8 J. Democracy 140, 140 (1997) ("Whether ... a society controls those who possess the ultimate power of physical coercion . . . is basic to democratic governance."); see also United Nations Off. on Drugs \& Crime, Handbook on Police Accountability, Oversight and Integrity 1 (2011), https://www.unodc.org/documents/justice-and-prison-reform/crimeprevention/PoliceAc countability_Oversight_and_Integrity_10-57991_Ebook.pdf [https://perma.cc/E9TD-QZ JV] ("[W] here policing ... may be undemocratic and authoritarian, efforts must be made to enhance civilian control over the police.”). 
In other arenas, when institutions perform poorly, we replace them. In business planning, firm structure is shaped by such economic considerations as transaction costs. ${ }^{20}$ We expect market competition to replace worse firms with better ones and hope that corporate law will enable shareholders to replace ineffective managers with more competent ones. ${ }^{21}$ In policy design, we don't simply ask what a given institution should do to solve a problem. We compare the information-gathering and decisionmaking competence of such institutions as courts, administrative agencies, and markets to determine which is best suited to address the problem. ${ }^{22}$ And of course, we expect competitive elections to replace policy decisionmakers.$^{23}$ In all these settings, we view the power to replace decisionmakers as an accountability mechanism.

So too, when the public expresses discontent with the performance of police agencies, we should ask not only whether their work can be done better, but whether it should be done at all, and by whom. As part of that inquiry, this Essay examines the appeal and feasibility of disbanding police agencies. "Disbanding" means legal dissolution of an agency-the organization ceases to exist, its expenditures cease, its jobs are eliminated. Collective bargaining agreements governing those jobs become inoperative. ${ }^{24}$ Disbanding the police does not, however, entail any commitments as to what happens after disbanding. It does not necessitate the abolition or the partial or total defunding of the law enforcement function. Instead, it may replace long-enduring police agencies with new forces, alternative forms of community governance and mutual aid, or whatever else a policymaker's imagination conjures. ${ }^{25}$ Thus, disbanding does not decide

20. See R.H. Coase, The Nature of the Firm, 4 Economica 386, 386-98 (1937).

21. See Roberta Romano, The Genius of American Corporate Law 15 (1993).

22. See Neil K. Komesar, Imperfect Alternatives: Choosing Institutions in Law, Economics and Public Policy 3 (1997) (“[C]hoices between markets, courts, and political processes pervade law and public policy at all levels.”).

23. See 9 Jeremy Bentham, Constitutional Code, in The Works of Jeremy Bentham 1, 47 (1843) ("A democracy, then, has for its characteristic object and effect, the securing [of] its members against oppression and depredation at the hands of those functionaries which it employs ....").

24. See infra notes $176-178$ and accompanying text.

25. See Friedman, Disaggregating, supra note 16 (manuscript at 4) (arguing for the need to critically examine the policing function itself and whether policing, as it is currently conceived, advances public safety). Compare Dionne Searcey \& John Eligon, Minneapolis Will Dismantle Its Police Force, Council Members Pledge, N.Y. Times (June 7, 2020), https://www.nytimes.com/2020/06/07/us/minneapolis-police-abolish.html (on file with the Columbia Law Review) ("Nine members of the Minneapolis City Council-a veto-proof majority-pledged ... to dismantle the Police Department, promising to create a new system of public safety."), with 10 Demands of BLMCHI, Black Lives Matter Chi., https:// www.blacklivesmatterchicago.com/10-demands-of-blmchi [https://perma.cc/MFS3-4RUZ] (last visited Jan. 16, 2021) (calling for the City of Chicago to "defund the police," for "immediate disinvestment" from the Chicago Police Department, and a reallocation of those operating funds toward community resources). 
whether police work will be done, or by whom-but it does open that question to democratic decision.

In fact, disbanding and replacing police agencies is a strategy that not only could be, but repeatedly has been used to reform law enforcement in the United States. ${ }^{26}$ As this Essay reveals, however, police agencies are harder to disband than many other governing institutions. They are entrenched, not only politically, but legally. In Minneapolis, for example, an unelected Charter Commission blocked the City Council's proposed referendum to disband and replace the city's police department, thus illustrating one of the many structural obstacles to dismantling even a politically unpopular police force. ${ }^{27}$

While disbanding police agencies does not achieve police abolition, the difficulty of doing so reveals something important about the abolitionist project. Policing, as we know it, is doubly entrenched. Policing practices are entrenched in police agencies, and police agencies are entrenched in governmental structures. Posing the problem of disbanding police agencies reveals that "the police" are not just a suite of (possibly unnecessary) functions, or a set of (possibly pernicious) practices, but also a distinctively unresponsive (and possibly illegitimate) legal and political institution. To fundamentally change how public safety is achieved in our society will also require removing police agencies from their status as autonomous public authorities and subjecting them to democratic control. Paradoxically, however, our current lack of democratic control over police agencies is the product of the many layers of ostensibly democratic supervision. The dense network of state, county, and local laws governing those agencies produces a structure democratic in form, which in practice serves to insulate police from meaningful reforms-and also impedes disbanding.

This Essay assesses disbanding police agencies from two points of view, framed by two questions. First, can we sufficiently improve the performance of law enforcement by reforming existing agencies? If not, we have reason to replace them. But second, assuming we have reason to replace

26. "Police agencies are ... disbanded with appreciable regularity, although this fact has been ignored by most in the academic policing community." William R. King, Organizational Failure and the Disbanding of Local Police Agencies, 60 Crime \& Delinquency 667, 668, 687 n.1 (2014) (citing disbandings of transit, housing, and school police in New York City and police departments in Compton, California; North Lauderdale, Florida; and Highland Park, Michigan). This study identified thirty-one dissolutions in Ohio over a ten-year period. Id. at 672. At least five were responses to corruption or excessive or selective enforcement. Id. at 682-683. Not counted among these thirty-one were other instances where "locales disbanded their agency, apparently to remove a chief and problem officers, and then created a new police agency staffed with personnel more to the locale's liking." Id. at 685.

27. See Astead W. Herndon, How a Pledge to Dismantle the Minneapolis Police Collapsed, N.Y. Times (Sept. 26, 2020), https://www.nytimes.com/2020/09/26/us/poli tics/minneapolis-defund-police.html (on file with the Columbia Law Review) (last updated Jan. 2, 2021); infra notes 197-210 and accompanying text. 
existing police agencies, is it feasible to do so? This question, in turn, depends on two further inquiries: Can police agencies be disbanded or substantially shrunk; and if so, how can they be replaced by something better?

Part I addresses the first question by examining the normative and prudential case for disbanding police agencies. It describes the toxic interaction of three pathologies of policing: first, the extraordinary and unwarranted scale of the American criminal system, with the highest incarceration rates in the world; second, the political insulation of police agencies from democratic accountability, especially to those most affected by their actions; and finally, both of these circumstances have helped make policing an instrument of racial subordination, reflected in an African American incarceration rate as much as six times that of whites. ${ }^{28}$ Part I then proceeds to identify several structural obstacles to effective reform of existing police agencies. Most such reforms rely on adding more oversight and training while leaving in place agency structures already performing these functions. Monitoring and sanctioning resistant organizations from the outside require both effort and political will that are difficult to sustain. Such efforts are likely to be systematically resisted by powerful police unions. ${ }^{29}$ Monitoring and training must also contend with an insular rankand-file culture of solidarity, secrecy, and mistrust of the public. In the face of these obstacles, reforms may accomplish little while provoking costly pushback, or may win cosmetic changes in return for expanding police agencies' mission and resources and enhancing their legitimacy. In either case, the high costs of reform may outweigh meager benefits. Given the pathologies of existing police forces, and the obstacles to their reform, there is indeed reason to disband them and build new institutions.

Part II addresses the feasibility of disbanding and replacing police agencies by examining the legal structures of the two most prevalent types of agencies in terms of numbers of agencies and officers: municipal police departments and county sheriffs' offices. ${ }^{30}$ This review yields three observations. First, the entrenchment of local law enforcement practices is due in part to the structural entrenchment of local law enforcement agencies. This entrenchment is easiest to see in the office of the sheriff, a constitutionally established state institution, independent of county government. Second, this structural entrenchment is often the result of political struggles between state and local governments, driven by cultural and economic conflicts, with the victors encoding political victories in law. This dynamic is particularly important in explaining the insulation of urban police departments. Third, the prospects for reform are further diminished by jurisdictional overlap between police, sheriffs' offices, and state police; and

28. See E. Ann Carson, DOJ, Bureau of Just. Stat., NCJ 253516, Prisoners in 2018, at 10 (2020), https://www.bjs.gov/content/pub/pdf/p18.pdf [https://perma.cc/G845-YF4X] (reporting that the imprisonment rates for Black adult residents and white adult residents were 1,500 per 100,000 and 272 per 100,000 respectively).

29. See infra section I.B.2.

30. State police agencies also are briefly discussed infra section II.C.3. 
among cities, counties, and states. For example, a city electorate that disbands its police force to reduce aggressive policing practices could find itself more aggressively policed by a sheriff's office answerable to a county electorate.

Having explicated structural impediments to both incremental reform and wholesale replacement of police agencies, the Essay turns, in Part III, to their strategic implications. First, these structural impediments reveal a law enforcement exceptionalism with respect to democratic accountability that, no less than the pathologies of policing, should be a target of reform. ${ }^{31}$ Police agencies, like the public authorities formed to bulldoze urban neighborhoods and flood farming communities, ${ }^{32}$ have been designed to operate outside of democratic controls. ${ }^{33}$ This democratic deficit is especially troubling for armed domestic security forces that, in total, outnumber all but four armies in the world. ${ }^{34}$ Second, the uniquely entrenched status of police forces did not arise by accident. Police agencies have been structurally immunized against reform by previous generations of reformers. This suggests that, third, where reformers win sufficiently broad support to overcome structural barriers and change practices, they should also strive to simplify police governance to create more flexible and democratic structures, leaving law enforcement exposed to further change and thereby empowering democratic publics with continuing leverage and influence. A necessary feature of such structural reform is to reduce veto points by subjecting policing to one layer of authority. Fourth, that one layer of democratic authority should be at the local level, where the human consequences of law enforcement are felt, and where communities of color have the greatest potential to exercise power.

31. Scholars have drawn attention to another dimension of law enforcement exceptionalism: the inapplicability of administrative law to law enforcement agencies. See Friedman \& Ponomarenko, supra note 14, at 1833, 1837-48, 1889-91; Christopher Slobogin, Policing as Administration, 165 U. Pa. L. Rev. 91, 95, 124-27 (2016) (arguing for an administrative rulemaking approach to police regulation). These works draw on an older literature proposing such controls. See, e.g., Anthony G. Amsterdam, Perspectives on the Fourth Amendment, 58 Minn. L. Rev. 349, 423 (1974); Kenneth Culp Davis, An Approach to Legal Control of the Police, 52 Tex. L. Rev. 703, 725 (1974).

32. See The Lost Towns of Pickwick, TVA, https://www.tva.com/about-tva/our-hist ory/built-for-the-people/the-lost-towns-of-pickwick [https://perma.cc/95UF-LQTT] (last visited Feb. 16, 2021) (recounting that the construction of Pickwick Landing Dam "result[ed] in the partial flooding of two towns, Waterloo and Riverton"); infra notes 420432 and accompanying text.

33. See infra sections I.A-.B.

34. See Int'l Inst. for Strategic Stud., The Military Balance 26 (2019) (noting that Russia, at 900,000, has the fourth most active military personnel in the world). 


\section{WHY DISBAND POLICE FORCES?}

This Part presents an argument for disbanding police agencies, emphasizing their resistance to incremental reform. ${ }^{35}$ Drawing on a deep well of recent scholarship, it identifies three pathologies of American policing. It then identifies a set of structural obstacles that stymie reform. A weakness of many police reform proposals is a failure to address the entrenchment of the policing institutions they are meant to improve. A strategy of disentrenchment-of disbanding-is therefore attractive.

\section{A. Three Pathologies of Policing}

Something is seriously wrong with policing in the United States. The grim facts are now familiar. Nearly a thousand people (disproportionately people of color) are fatally shot each year by police officers. ${ }^{36}$ And the pathologies of policing extend well beyond killings: excessive force, invasive stops, militarized terror, and more. ${ }^{37}$ We would add little to the literature by cataloging the litany of other problems. But to understand the case for disbanding, it is particularly important to recognize three fundamental pathologies of policing.

35. Disbanding police agencies is compatible with, but does not entail, the more ambitious project of abolishing punishment and policing. For explications of that project and specific suggestions for policy reforms, see generally Angela Y. Davis, Are Prisons Obsolete? (2003) (outlining the case for prison abolition); Amna A. Akbar, Toward A Radical Imagination of Law, 93 N.Y.U. L. Rev. 405, 415 (2018) [hereinafter Akbar, Radical Imagination] (examining the Black Lives Matter movement, advocating for "fundamental, structural reform that ... reconceive[s] the proper relationship between state, market, and society" and builds power within Black communities); Allegra M. McLeod, Envisioning Abolitionist Democracy, 132 Harv. L. Rev. 1613, 1616 (2019) (arguing for an abolitionist approach to criminal justice, "where punishment is abandoned in favor of accountability and repair"); Simonson, Power Lens, supra note 14, at 787 (providing an "account of why [scholars and reformers] should incorporate the power lens into the array of objectives of 'police reform'”).

36. At the time of writing, 5,489 people had been shot and killed by the police since January 1, 2015. See Fatal Force, Wash. Post, https://www.washingtonpost.com/graphics/ investigations/police-shootings-database/ (on file with the Columbia Law Review) (last updated Jan. 27, 2021); see also Catherine Barber, Deborah Azrael, Amy Cohen, Matthew Miller, Deonza Thymes, David Enze Wang \& David Hemenway, Homicides by Police: Comparing Counts from the National Violent Death Reporting System, Vital Statistics, and Supplementary Homicide Reports, 106 Am. J. Pub. Health 922, 924 (2016) (finding ethnic disparities of eight to one in police killings); Jeffrey Fagan \& Alexis D. Campbell, Race and Reasonableness in Police Killings, 100 B.U. L. Rev. 951, 960-61 (2020) (finding that, even where there are no circumstances that would render a shooting objectively reasonable for Fourth Amendment purposes, Black suspects are more than twice as likely than other suspects to be killed by police); Justin M. Feldman, Roland Fryer Is Wrong: There Is Racial Bias in Shootings by Police, Scholars at Harv.: Justin Feldman Blog (July 12, 2016), http:// scholar.harvard.edu/jfeldman/blog/roland-fryer-wrong-there-racial-bias-shootings-police [https://perma.cc/ZRE5-SSRT] (finding that in Houston, Blacks were nearly five times more likely than whites to be shot by police).

37. See Friedman \& Ponomarenko, supra note 14, at 1829-31. 
First, the sheer scale of the American criminal system is unlike any other in history. The United States incarcerates its inhabitants at a rate that is unprecedented comparatively ${ }^{38}$ and has few historical parallels. ${ }^{39}$ Although it has declined in recent years, the U.S. incarceration rate remains the highest in the world. ${ }^{40}$ As Professor Dylan Rodríguez has recently observed, that rate (which peaked at 1,000 per 100,000 people in 2008) is matched in recent history only by those of "apartheid South Africa, the Gulag-era Soviet Union, and the Russian Federation during the immediate post-Soviet Union years." 41

This statistic is largely, but not exclusively, a racialized one ${ }^{42}$ If every nonwhite inmate were released from prison immediately, the United States' rate of incarceration would still vastly exceed that of any Western European country. ${ }^{43}$ Furthermore, the growth in the United States incarceration rate appears to track increased class disparities that have resulted from reduced labor market opportunities, high concentrations of poverty in urban neighborhoods, and the deterioration of social services. ${ }^{44}$

Beyond incarceration rates, the policing apparatus is itself massive..$^{45}$ Professor Amna Akbar has recently argued that the scale of policingincluding its size and power-renders counterproductive any incremental

38. See Comm. on Causes \& Consequences of High Rates of Incarceration, Nat'l Rsch. Council, The Growth of Incarceration in the United States: Exploring Causes and Consequences 68 (Jeremy Travis, Bruce Western \& Steve Redburn eds., 2014).

39. See Dylan Rodríguez, Abolition as Praxis of Human Being: A Foreword, 132 Harv. L. Rev. 1575, 1584 (2019).

40. See John Gramlich, Black Imprisonment Rate in the U.S. Has Fallen by a Third Since 2006, Pew Rsch. Ctr. (May 6, 2020), https:/ / www.pewresearch.org/fact-tank/2020/05 /06/share-of-black-white-hispanic-americans-in-prison-2018-vs-2006 [https://perma.cc/ET W3-SYDA].

41. Rodríguez, supra note 39 , at 1584 (footnotes omitted).

42. See infra notes 57-64 and accompanying text.

43. See Ram Subramanian, Kristine Riley \& Chris Mai, Vera Inst. of Just., Divided Justice: Trends in Black and White Jail Incarceration, 1990-2013, at 8 (2018) (observing that white jail incarceration rates grew across all regions and jurisdiction types during the time period studied). Compare Carson, supra note 28, at 9 tbl.5 (noting that the imprisonment rate of sentenced white prisoners is 218 per 100,000), with Roy Walmsley, Inst. for Crim. Pol'y Rsch., World Prison Population List 11 tbl.4 (12th ed. 2018), https://www.prisonstudies.org/sites/default/files/resources/downloads/wppl_12.pdf [https://perma.cc/4UBH-B5DZ] (noting the highest incarceration rate in Western Europe is Luxembourg's 107 people per 100,000).

44. See John Clegg \& Adaner Usmani, The Economic Origins of Mass Incarceration, Catalyst (2019), https://catalyst-journal.com/vol3/no3/the-economic-origins-of-massincarceration [https://perma.cc/YTG9-T68C]. This explanation is consistent with theories that trace mass incarceration to structural racism. See id. ("American slavery and ... Jim Crow delayed the proletarianization of African Americans, with the result that they arrived in Northern cities after the first wave of ... industrialization, in urban environments in which pivotal, scarce resources (jobs and housing) were hoarded by the first and second generations of established white ethnics."); see also Ruth Wilson Gilmore, Golden Gulag: Prisons, Surplus, Crisis, and Opposition in Globalizing California 7-11 (2007).

45. See supra notes $16-18$. 
reforms that require investments in police forces. ${ }^{46}$ Modern policing in the United States is also far more intrusive in scope and substance than could have been contemplated in prior centuries. Progressive Era reforms enabled police departments to grow their bureaucracies independently of meaningful political checks. ${ }^{47}$ The rise of automobile culture gave police a new and expanding function and helped transform policing into an active process of stops and surveillance. ${ }^{48}$ Beginning in the 1960 s, the scale of urban policing grew alongside the War on Crime. ${ }^{49}$ As law enforcement bureaucracies continued to expand, while social services shrank, police and prisons have, as Akbar observes, become "a primary mode of the state's presence, especially in the lives of poor and working-class people of color." ${ }^{50}$

Second, police departments in the United States operate outside of traditional mechanisms of democratic accountability. As a formal matter, sheriffs and municipal police chiefs continue to be directly or indirectly accountable to the electorate.$^{51}$ In practice, however, police departments operate in a "democratic vacuum." 52 Professor Markus Dubber has argued that the role of American police reflects a tradition of patriarchal governance in deep tension with American ideals of self-governance. ${ }^{53}$ This tension increased as police departments evolved into bureaucratic institutions, intentionally insulated from political influence. ${ }^{54}$ Unlike other agencies, police departments are rarely constrained by legislation or regulations subject to public input. ${ }^{55}$ This vast and unregulated discretion

46. See Amna A. Akbar, An Abolitionist Horizon for (Police) Reform, 108 Calif. L. Rev. 1781, 1782-88 (2020) [hereinafter Akbar, Abolitionist Horizon] (addressing the scale of policing as a cause for and target of abolitionist activism).

47. See infra notes 270-280 and accompanying text.

48. See Sarah A. Seo, Policing the Open Road: How Cars Transformed American Freedom 7-20 (2019).

49. See Jonathan Simon, Is Mass Incarceration History?, 95 Tex. L. Rev. 1077, 1101 (2017) (reviewing Hinton, supra note 7).

50. See Wacquant, supra note 7 , at 41 ("Over the past three decades... America has ... gradual[ly] replace[d] ... a (semi-) welfare state by a police and penal state for which the criminalization of marginality and the punitive containment of dispossessed categories serve as social policy ....”); Akbar, Abolitionist Horizon, supra note 46, at 1822.

51. See Friedman \& Ponomarenko, supra note 14, at 1858-65 (describing the history of police accountability throughout the twentieth century); infra notes 278, 288 and accompanying text.

52. Friedman \& Ponomarenko, supra note 14, at 1835; see also Erik Luna, Transparent Policing, 85 Iowa L. Rev. 1107, 1111-17 (2000) [hereinafter Luna, Transparent Policing] (explaining that "hidden episodes" of police misconduct avoid public accountability).

53. Markus Dirk Dubber, The Police Power: Patriarchy and the Foundations of American Government 81-82 (2005). For a more sanguine association of the police power with local self-governance, see William J. Novak, The People's Welfare: Law and Regulation in Nineteenth Century America 9-10, 51-82 (1996).

54. See infra section II.A.2.

55. See Friedman \& Ponomarenko, supra note 14, at 1837-54 ("Compared to the sprawling administrative codes that detail every aspect of agency practice, laws governing the police are notably sparce-if they exist at all."). 
means that politicians will rarely be held accountable for police misconduct and that the electorate will have difficulty meaningfully assessing or debating police practices. ${ }^{56}$

Third, whether by design or by happenstance, American policing contributes to the continued subordination of Black and brown people in the United States. ${ }^{57}$ People of color are more likely to be burdened by excessive fines and fees. ${ }^{58}$ Black people in poor neighborhoods are far more likely than others to be stopped by police ${ }^{59}$ Black and brown people are more likely to be subjected to excessive force and killed by the police ${ }^{60}$ These inequalities of enforcement create a pool of potential defendants that prosecutors can selectively charge in ways that create grotesque racial disparities in our prisons. ${ }^{61}$ Moreover, Professors Bruce Western and Christopher Muller observe that "inequalities of race and class combine to produce astonishing rates of penal confinement among Black men with little schooling." ${ }^{62}$ And while the rate of Black imprisonment in the United

56. See Debra Livingston, Police Discretion and the Quality of Life in Public Places: Courts, Communities, and the New Policing, 97 Colum. L. Rev. 551, 657 (1997); Luna, Transparent Policing, supra note 52, at 1117.

57. See Simonson, Power Lens, supra note 14, at 805-06 (explicating the concept of "race-class subjugated communities" in legal scholarship). See generally Joe Soss \& Vesla Weaver, Police Are Our Government: Politics, Political Science, and the Policing of RaceClass Subjugated Communities, 20 Ann. Rev. Pol. Sci. 565, 565-67 (2017) (arguing that policing helps construct "race-class subjugated communities"); Radley Balko, Opinion, There's Overwhelming Evidence that the Criminal Justice System Is Racist. Here's the Proof., Wash. Post (June 10, 2020), https://www.washingtonpost.com/graphics/2020/ opinions/systemic-racism-police-evidence-criminal-justice-system (on file with the Columbia Law Review) (identifying racial disparities in policing).

58. See Brandon L. Garrett, Wealth, Equal Protection, and Due Process, 61 Wm. \& Mary L. Rev. 397, 449 (2019).

59. See Floyd v. City of New York, 959 F. Supp. 2d 540, 558-59 (S.D.N.Y. 2013) (finding, based on a study of 4.4 million stops made in New York City, that eighty-three percent of people stopped were either Black or Hispanic); Jeffrey Fagan \& Amanda Geller, Following the Script: Narratives of Suspicion in Terry Stops in Street Policing, 82 U. Chi. L. Rev. 51, 55-58 (2015) (discussing how police officers "have developed recurring narratives or scripts of suspicion to satisfy administrative review of their actions and ... are [also] more likely to view a minority citizen as suspicious based on nonbehavioral cues"); see also Charles R. Epp, Steven Maynard-Moody \& Donald Haider-Markel, Pulled Over: How Police Stops Define Race and Citizenship 3 (2014) (" $[\mathrm{I}] \mathrm{t}$ is well established that racial minorities are more likely than whites to be stopped by the police.... [R] acial minorities are questioned, handcuffed, and searched at dramatically higher rates than whites are ....”).

60. See Balko, supra note 57 (summarizing studies on police shootings).

61. See Carson, supra note 28, at 9 tbl.5 (reporting that the rate of sentenced Black prisoners is 1,134 per 100,000 compared to 218 sentenced white prisoners per 100,000$)$; John F. Pfaff, Locked In: The True Causes of Incarceration and How to Achieve Real Reform 145-47 (2017) (arguing that racial disparity has been shaped by prosecutorial decisions).

62. Bruce Western \& Christopher Muller, Mass Incarceration, Macrosociology, and the Poor, 647 Ann. Acad. Pol. \& Soc. Sci. 166, 166 (2013) (observing that the "[c]hances that a black man with no college education would serve time in prison were about 12 percent in the late 1970 s, compared to 35 percent today"). 
States has declined in recent years, ${ }^{63}$ it still dwarfs the total imprisonment rate of any other country. ${ }^{64}$

These disparate harms reflect a mode of policing governance that is experienced differently by poor people of color than by others.$^{65}$ For example, the War on Drugs has shaped the lives of poor communities of color by expanding state police budgets (including through federal grants and asset forfeiture) in an era when other social services were being slashed. ${ }^{66}$ These budgetary expansions gave rise to specialized narcotics units in local police departments that were given free rein in poor communities of color ${ }^{67}$ During this period, resources were diverted from mental health and other social services into the budgets of prisons and police departments. ${ }^{68}$ While the drug war may not have been directly responsible for mass incarceration, ${ }^{69}$ it damaged the economic opportunities of poor people of color (including through collateral consequences in the labor and housing markets),${ }^{70}$ and "estranged" communities of color from institutions ostensibly there to protect them. ${ }^{71}$ Misdemeanor enforcement

63. See Gramlich, supra note 40.

64. Compare Carson, supra note 28, at 1 (reporting that the imprisonment rate of sentenced Black prisoners is 1,134 per 100,000 Black residents), with Walmsley, supra note 43, at 2 (reporting that El Salvador, which is second to the United States in its incarceration rate, imprisons 604 people per 100,000 residents).

65. See, e.g., Jonathan Simon, Governing Through Crime: How the War on Crime Transformed American Democracy and Created a Culture of Fear 18-20 (2007) (arguing that crime politics does not exclusively affect the poor and African Americans but "actively reshapes how power is exercised throughout hierarchies of class, race, ethnicity, and gender").

66. See Erik Luna, Drug War and Peace, 50 U.C. Davis L. Rev. 813, 837 (2016) (noting the dependence of police departments on federal drug war grants); David W. Rasmussen \& Bruce L. Benson, Rationalizing Drug Policy Under Federalism, 30 Fla. St. U. L. Rev. 679, 717 (2003) ("Research indicates that police department discretionary budgets rise when they seize assets and that departments respond to this incentive by increasing drug arrests relative to arrests for other offenses.").

67. See Monica C. Bell, Police Reform and the Dismantling of Legal Estrangement, 126 Yale L.J. 2054, 2118 (2017) [hereinafter Bell, Legal Estrangement].

68. See Bernard E. Harcourt, The Illusion of Free Markets: Punishment and the Myth of Natural Order 221-39 (2011).

69. See Pfaff, supra note 61 , at 13 ("[O]nly about 16 percent of state prisoners are serving time on drug charges . ...”). Professor John Pfaff argues that convictions for violent crimes drove the explosion in prison population. See id. But Pfaff acknowledges that prior convictions for drug offenses are likely to shape charging decisions for violent offenses. See id. at 42-43. Also, most inmates serving time in or awaiting trial at local jails are being held in connection with nonviolent offenses. See Wendy Sawyer \& Peter Wagner, Mass Incarceration: The Whole Pie 2020, Prison Pol'y Initiative (Mar. 24, 2020), https://www. prisonpolicy.org/reports/pie2020.html [https://perma.cc/2ZAL-CQAJ] (reporting that of approximately 746,000 people in local jails, 149,000 were detained on violent charges and another 34,000 were sentenced for violent offenses).

70. See Benjamin Levin, The Consensus Myth in Criminal Justice Reform, 117 Mich. L. Rev. 259, 280 (2018).

71. See Bell, Legal Estrangement, supra note 67, at 2083 (defining legal estrangement). 
is another arena of subordination, forcing targeted populations to endure procedural hassle and comply with arcane rules, and the consequences of misdemeanor arrest for the poor can mean the loss of jobs and housing. ${ }^{72}$ Much police work, such as mental health intervention and low-level dispute resolution, is outside the sphere of law enforcement altogether ${ }^{73}$ These noncriminal aspects of policing can also reinforce patterns of segregation. ${ }^{74}$ Abolitionists have traced the origins of the policing system of the American South to eighteenth- and nineteenth-century slave patrols ${ }^{75}$ and argued that the social control of communities of color has long been a central focus of American policing. ${ }^{76}$ In this respect, Professor Paul Butler argues that the system is working the way it's supposed to. ${ }^{77}$ Regardless of whether one accepts this narrative, there is a wide consensus that trust has broken down between police departments and poor communities of color. ${ }^{78}$

By themselves, these pathologies of policing do not establish disbanding as the appropriate remedy. Consider that in neighborhoods with concentrations of impoverished people of color, overpolicing of nonviolent crime often coexists with the underpolicing of violent crimes. ${ }^{79}$ These

72. See Issa Kohler-Hausmann, Misdemeanorland: Criminal Courts and Social Control in an Age of Broken Windows Policing 267 (2019) ("The residents [of poor and minority] communities are the ones who come to have criminal records that hinder their employment and housing prospects....").

73. See supra note 16 and accompanying text.

74. See Monica C. Bell, Anti-Segregation Policing, 95 N.Y.U. L. Rev. 650, 702-03 (2020) ("When a neighbor calls the police on another neighbor to report a fairly innocuous infraction, such as noisiness, or an incident [of] . . . intimate partner violence, it can set off a chain of events that leads to an eviction ... exact[ing] an additional, collective harm of perpetuating segregation.”).

75. See Vitale, supra note 4, at 95-100 (examining links between slave patrols and subsequent policing institutions); Akbar, Radical Imagination, supra note 35, at 447-60 (drawing connections between slavery abolition and punishment abolition). See generally Laurence Ralph, The Logic of the Slave Patrol: The Fantasy of Black Predatory Violence and the Use of Force by the Police, Palgrave Commc'ns, Oct. 2019, at 1 (providing an ethnographic account of African American perceptions of these linkages in contemporary Chicago).

76. See Zack Beauchamp, What the Police Really Believe, Vox (July 7, 2020), https://www.vox.com/policy-and-politics/2020/7/7/21293259/police-racism-violenceideology-george-floyd (on file with the Columbia Law Review).

77. See Paul Butler, The System Is Working the Way It Is Supposed To: The Limits of Criminal Justice Reform, 104 Geo. L.J. 1419, 1421-26 (2016) [hereinafter Butler, The System] ("The Court has . . creat[ed] a system where racially unjust police conduct is both lawful and how the system is supposed to work.").

78. See, e.g., Bell, Legal Estrangement, supra note 67, at 2058 (noting that many scholars argue that "people of color and residents of high-poverty communities do not trust the police").

79. Jeffrey Fagan \& Daniel Richman, Understanding Recent Spikes and Longer Trends in American Murders, 117 Colum. L. Rev. 1235, 1278-79 (2017) (noting that residents of neighborhoods with high homicide rates "experience policing as detached from serious crime and aimed at the wrong behaviors and the wrong people"); Alexandra Natapoff, 
phenomena are mutually reinforcing. Mistrust of the police deters people from cooperating with them to solve murders and violent crimes. ${ }^{80}$ And community resistance to overpolicing often prompts police officers to abandon their responsibilities toward those communities. ${ }^{81}$ Some Blackled social movements have responded to this dynamic by calling for increased policing, ${ }^{82}$ while others have advocated for abolition. ${ }^{83}$

There is a wide consensus, however, that some reform is necessary. Unfortunately, the institutional context of American policing ensures that most reforms are bound to fail.

\section{B. Structural Obstacles to Police Reform}

The case for disbanding police forces is rooted in four structural obstacles that often doom incremental reforms to failure. First, the current enthusiasm for police reform notwithstanding, lack of political will is a persistent barrier to meaningful reform. Second, police unions have proven successful not only in contracting around accountability but also in using the political process to block reform. Third, the culture of policing itself serves as a barrier to reducing police violence. And fourth, any reforms that can overcome these structural obstacles will involve significant tradeoffs that could worsen the pathologies of policing in some respects.

1. Lack of Political Will. - The current political moment is exceptional in terms of the political energy behind police reform. But if history serves as a guide, this political energy may be short lived. ${ }^{84}$ Consider, for example, the limited success of federal consent decrees. When the political will exists, policing is often amenable to state and federal oversight through litigation and judicial supervision. ${ }^{85}$ In some contexts, consent

Underenforcement, 75 Fordham L. Rev. 1715, 1724-27 (2006) (analyzing official neglect of serious crime in urban neighborhoods inhabited by people of color).

80. See Fagan \& Richman, supra note 79, at 1248.

81. See id.

82. See James Forman, Jr., Locking Up Our Own: Crime and Punishment in Black America 11 (2017) (noting that Black officials have advocated for "tough-on-crime measures in race-conscious terms" and "expanded police forces and courts—state resources they had historically been denied"); Michael Javen Fortner, Black Silent Majority: The Rockefeller Drug Laws and the Politics of Punishment 62 (2015) (describing African American support for increased policing in the latter half of the twentieth century); John Rappaport, Some Doubts About "Democratizing" Criminal Justice, 87 U. Chi. L. Rev. 711, 787-91 (2020) (surveying scholarship documenting Black support for punitive crime policies).

83. See Akbar, Abolitionist Horizon, supra note 46, at 1800-02.

84. Indeed, there is strong evidence that support for policing reform is already waning among white Americans. See Michael Tesler, Support for Black Lives Matter Surged During Protests, But Is Waning Among White Americans, FiveThirtyEight (Aug. 19, 2020), https:// fivethirtyeight.com/features/support-for-black-lives-matter-surged-during-protests-but-is-wa ning-among-white-americans [https://perma.cc/8KWG-Z7ED].

85. See K. Sabeel Rahman \& Jocelyn Simonson, The Institutional Design of Community Control, 108 Calif. L. Rev. 679, 685 (2020); Stephen Rushin, Structural Reform Litigation in American Police Departments, 99 Minn. L. Rev. 1343, 1396-406 (2015) [hereinafter Rushin, Structural Reform Litigation]; see also Rachel A. Harmon, Federal 
decrees appear to reduce incidents of civil rights violations. ${ }^{86}$ But federal enforcement depends on politicized discretion. On assuming office, the Trump administration announced that it would no longer use the DOJ's authority to investigate and bring lawsuits against local police departments for constitutional violations. ${ }^{87}$ Although state attorneys generally have sought to fill the void, they are hobbled by federal standing limitations and other constraints. ${ }^{88}$

But even previous administrations have made nationwide police reform at best a minor part of their policy agenda. Before the Trump era, the DOJ investigated about three police departments per year on average ${ }^{89}$ The Obama Administration, which prioritized police oversight to a greater degree than any other recent administration, ${ }^{90}$ opened only thirty-six investigations, ${ }^{91}$ in a nation with almost 18,000 state and local police agencies. ${ }^{92}$ Some treat this limitation as one of capacity: After all, the budget of the DOJ's Civil Rights Division is dwarfed by that of other units in the agency. ${ }^{93}$ Yet, for a government with virtually unlimited resources, lack of capacity and lack of political will are one and the same. ${ }^{94}$

Programs and the Real Costs of Policing, 90 N.Y.U. L. Rev. 870, 953 (2015) [hereinafter Harmon, Real Costs of Policing] (discussing how DOJ settlements with local police departments are "designed to promote ... departmental accountability to the public" but acknowledging that "federal efforts to improve local policing can undermine the political checks that ordinarily ensure that ... it is responsive to community concerns").

86. See, e.g., Zachary A. Powell, Michele Bisaccia Meitl \& John L. Worrall, Police Consent Decrees and Section 1983 Civil Rights Litigation, 16 Criminology \& Pub. Pol'y 575, 577 (2017) ("DOJ consent decrees are associated with modest reductions in . . civil rights violations . ...”); Rushin, Structural Reform Litigation, supra note 85, at 1397 (arguing that structural reform litigation is "uniquely successful in part because it forces municipalities to prioritize investments into police reform over other municipal goals").

87. See Jason Mazzone \& Stephen Rushin, State Attorneys General as Agents of Police Reform, 69 Duke L.J. 999, 1005-06 \& nn.30-31 (2020).

88. See id. at 1033-50 (analyzing the use of parens patriae doctrine to allow state attorneys general to sue in federal courts and concluding that " $[\mathrm{e}]$ xisting laws are largely inadequate to control misconduct in local police departments").

89. See Rushin, Structural Reform Litigation, supra note 85, at 1370-71.

90. See, e.g., President's Task Force on 21st Century Policing, Final Report of the President's Task Force on 21st Century Policing 1, 46 (2015), https://cops.usdoj.gov/pdf/ taskforce/taskforce_finalreport.pdf [https://perma.cc/K2NB-TLQQ] (calling for greater cooperation between communities and the police agencies that serve them in order to promote public trust and legitimacy); Developments in the Law: Policing, 128 Harv. L. Rev. 1706, 1709 (2015) (noting that the President's Task Force was the "first national commission on systemic policing reform in more than fifty years").

91. Patel, supra note 14, at 794-95 (stating, based on DOJ data that appear to no longer be available on its website, that the Special Litigation Section under Obama opened thirtysix investigations).

92. See supra note 18 and accompanying text.

93. See, e.g., Rushin, Structural Reform Litigation, supra note 85, at 1415 ("Another potential drawback of $\S 14141$ is that the federal government simply lacks the resources necessary for aggressive enforcement.").

94. Indeed, the operational reliance of federal law enforcement on local police agencies suggests that the Civil Rights Division's diminished capacity is by design. See Daniel 
But even the most vigorous federal enforcement will fail in the absence of political will at the local and state levels. As Professor Stephen Rushin observes, there are serious questions as to whether the reforms made during federal interventions are sustainable after monitoring ends. ${ }^{95}$ Absent support from police chiefs and other local leaders, structural reform litigation is unlikely to be successful. ${ }^{96}$ But this support comes at a high price to local leadership. Local municipalities must bear most of the high costs of complying with federal consent decrees, ${ }^{97}$ requiring them to slash budgets or raise taxes. ${ }^{98}$ This, in turn, can lead to significant public backlash against any police reforms. ${ }^{99}$

At the state level, support for policing reform often appears to be a losing position. Reformers had cause to celebrate when the State of New York passed legislation that banned the use of chokeholds and eliminated barriers to cities releasing police disciplinary records. ${ }^{100}$ But these legislative reforms had languished for years before the recent protests prompted state officials to enact the law. ${ }^{101}$ Such legislative inertia comes as little surprise. The same political incentives that push legislators toward increasingly punitive results push them away from regulating police. ${ }^{102}$ Moreover, legislation at the state and county levels is unlikely to reflect the interests of urban-dwelling African Americans who face the greatest risk of police brutality. ${ }^{103}$ Professor Monica Bell has argued that, with respect to criminal justice reform, "African Americans-particularly if they live in high-poverty communities-have relatively little say in who their representatives are or in the legislation that their representatives ultimately

Richman \& Sarah A. Seo, How Federalism Built the FBI, Sustained Local Police, and Left Out the States, 17 Stan. J.C.R. \& C.L. (forthcoming 2021) (manuscript at 2-3), https://ssrn.com/abstract=3714325 (on file with the Columbia Law Review) ("The working relationship of mutual exchange, or collaborative federalism, rendered the federal government largely unwilling to hold the police accountable for how they performed their jobs.").

95. See Rushin, Structural Reform Litigation, supra note 85, at 1410-12.

96. See id. at $1417-18$.

97. See id. at $1408-09$.

98. See id. at 1409.

99. Id.

100. See Luis Ferré-Sadurní, Jeffrey C. Mays \& Ashley Southall, Defying Police Unions, New York Lawmakers Ban Chokeholds, N.Y. Times (June 8, 2020), https://www.nytimes. com/2020/06/08/nyregion/floyd-protests-police-reform.html (on file with the Columbia Law Review).

101. See id.

102. See William J. Stuntz, The Pathological Politics of Criminal Law, 100 Mich. L. Rev. 505, 509-12 (2001) (examining how political incentives contribute to expanded discretion for prosecutors and police officers).

103. See William J. Stuntz, The Collapse of American Criminal Justice 7 (2011) [hereinafter Stuntz, Collapse of American Criminal Justice] (describing how demographic changes have "limited the [voting] power of residents of poor city neighborhoods-the neighborhoods where levels of criminal violence are highest"). 
pass." 104 Even increased democratic control over legislatures will not necessarily lead to reduced support for police. As Professor John Rappaport observes in his systematic critique of a scholarly manifesto for "democratizing" criminal justice, ${ }^{105}$ there is considerable evidence that lay people have more punitive attitudes than elites. ${ }^{106}$ Moreover, it is a matter of controversy whether, under current electoral structures, greater African American enfranchisement will lead to less punitive outcomes. ${ }^{107}$

2. Police Unions. - A related structural obstacle to police reform is that it often requires the cooperation of police unions that are hostile to reform and skilled at preventing it. ${ }^{108}$ As Professors Catherine Fisk and L. Song Richardson explain, rank-and-file police officers fear they will be subjected to unfair discipline by departmental bureaucracies that they view as capricious, unpredictable, and punitive. ${ }^{109}$ Rank-and-file officers therefore rely on their unions to resist any police reforms that would expose them to such discipline. And these unions are effective. ${ }^{110}$ Recently compiled data on collective bargaining agreements (CBAs) confirms long-held assumptions that police unions are obstacles to accountability. ${ }^{111}$

104. Bell, Legal Estrangement, supra note 67, at 2142-44 (questioning the likely efficacy of administrative solutions to regulate police through democratically informed rulemaking).

105. See Rappaport, supra note 82; cf. Joshua Kleinfeld, Laura I. Appleman, Richard A. Bierschbach, Kenworthey Bilz, Josh Bowers, John Braithwaite, Robert P. Burns, R A Duff, Albert W. Dzur, Thomas F. Geraghty, Adriaan Lanni, Marah Stith McLeod, Janice Nadler, Anthony O'Rourke, Paul H. Robinson, Jonathan Simon, Jocelyn Simonson, Tom R. Tyler \& Ekow N. Yankah, White Paper of Democratic Criminal Justice, 111 Nw. U. L. Rev. 1693, 1699-1700 (2017). One of the coauthors of this Essay was also a coauthor of the "White Paper," and supports many but not all of its recommendations. See id. at 1695 ("[T]he policy proposals below do not reflect and should not be taken to reflect any individual author's views in full.").

106. See Rappaport, supra note 82 , at 759-73.

107. See Forman, supra note 82, at 9 (noting that sixty-four percent of African Americans surveyed believed that courts were not harsh enough on criminals); Rappaport, supra note 82, at 787-91 (arguing that "under existing structural constraints, one should not too quickly predict that, if given greater control over criminal justice policy, black Americans will necessarily temper it").

108. See Catherine L. Fisk \& L. Song Richardson, Police Unions, 85 Geo. Wash. L. Rev. 712, 720 (2017) (noting the "history of police rank-and-file resistance to imposition of reforms without their input”); see also Rachel A. Harmon, The Problem of Policing, 110 Mich. L. Rev. 761, 798-99 (2012) (discussing the use of collective bargaining to block police reforms); Aziz Z. Huq, Fourth Amendment Gloss, 113 Nw. U. L. Rev. 701, 743 (2019) (noting that police unions are associated with more coercive policing).

109. See Fisk \& Richardson, supra note 108, at 726.

110. See id. at 726-28, 756 (describing how union representatives for large departments could control a "multimillion-dollar budget" which "gives them enormous power to influence public policy" through political donations).

111. See Stephen Rushin, Police Union Contracts, 66 Duke L.J. 1191, at apps. A \& B (2017) [hereinafter Rushin, Police Union Contracts]; George Joseph, Leaked Police Files Contain Guarantees Disciplinary Records Will Be Kept Secret, Guardian (Feb. 7, 2016), http:/ /www.theguardian.com/us-news/2016/feb/07/leaked-police-files-contain-guarantees-disciplinary-records-will-be-kept-secret [https://perma.cc/X69J-QCSB]; Fair Police 
To begin, there appears to be a strong correlation between the collective bargaining power of a police workforce and the incidence of violent misconduct among its members. ${ }^{112}$ This correlation is unsurprising. As Fisk and Richardson have observed, several aspects of police contracts are particularly problematic. ${ }^{113}$ Most contracts slow down misconduct investigations through protections, such as those provided by a Law Enforcement Officers' Bill of Rights (LEOBOR). ${ }^{114}$ Police contracts also shield disciplinary records from the public, making it difficult to hold officers accountable for misconduct. ${ }^{115}$ Some CBAs limit civilian oversight. ${ }^{116}$ Many also require that rank-and-file members sit on disciplinary hearing boards, rendering it more difficult to sanction officers for wrongdoing. ${ }^{117}$

Beyond their collective bargaining power, police unions are well positioned to leverage the political process to block reforms. ${ }^{118}$ At the state and local levels, police unions have successfully promoted legislation that shields officers from accountability and have blocked even uncontroversial reforms. ${ }^{119}$ In some states-including Minnesota, where George Floyd and Philando Castile were killed-LEOBORS are codified by statute. ${ }^{120}$ Part of this success owes to the uncharacteristically close relationships that police unions have with Republican as well as Democratic politicians. ${ }^{121}$ Thus, even in states that have dismantled protections for public sector unions, the pensions and prerogatives of police unions have gone untouched. ${ }^{122}$

When police unions do not oppose reform, their bargaining strength diverts resources from social services that could serve as alternatives to

Contracts, Campaign Zero, https://www.joincampaignzero.org/contracts [https://perma. cc/Y4EF-LAV8] (last visited Jan. 30, 2020).

112. See Dhammika Dharmapala, Richard H. McAdams \& John Rappaport, Collective Bargaining Rights and Police Misconduct: Evidence from Florida, J.L. Econ. \& Org. (forthcoming 2022) (manuscript at 25-27, 30), https://ssrn.com/abstract=3095217 (on file with the Columbia Law Review) (finding that, following a decision conferring collective bargaining rights on sheriffs' deputies, violent incidents of misconduct rose substantially in sheriffs' offices relative to police departments that did not obtain such rights).

113. See Fisk \& Richardson, supra note 108, at 750-55.

114. See Kate Levine, Police Suspects, 116 Colum. L. Rev. 1197, 1200-02 (2016) (arguing that LEOBORs provide protections that should extend to all criminal suspects).

115. See Fisk \& Richardson, supra note 108, at 751-52.

116. See id. at 753 .

117. See id. at $753-54$.

118. See id. at 744-45.

119. See, e.g., Ferré-Sadurní et al., supra note 100 (describing the role of police unions in blocking legislation that bans chokeholds and preserving legislation that prevents the disclosure of disciplinary records).

120. See, e.g., Minn. Stat. $\$ 626.89$ (2020).

121. See, e.g., Benjamin Levin, What's Wrong with Police Unions?, 120 Colum. L. Rev. 1333, 1352 (2020) [hereinafter Levin, Police Unions] (describing the close relationship between the Fraternal Order of Police and Trump).

122. See id. at $1357-58$. 
policing. ${ }^{123}$ The core function of police unions is to bargain for salaries, and they perform this function well. For example, the average starting salary for law enforcement officers is around thirty-eight percent higher in unionized departments than in non-unionized ones. ${ }^{124}$ Moreover, given their uncharacteristic influence over GOP politics, police unions have an edge over other public sector unions that Republicans have targeted. ${ }^{125}$

As Professor Ben Levin has argued, police unions sometimes may be scapegoats for politicians who are disinclined to support police reform or invest in social service alternatives to policing. ${ }^{126}$ As a descriptive matter, however, Levin's observation merely identifies another way that union influence and lack of political will can work in tandem as structural obstacles to reform. The bargaining strength of police unions is part of the context explaining Professor Michelle Alexander's observation that "poor African Americans are not given the option of great schools, community investment, and job training. Instead, they are offered police and prisons. If the only choice that is offered blacks is rampant crime or more prisons, the predictable (and understandable) answer will be 'more prisons." "127

3. Rank-and-File Culture. - If police unions are the faithful agents they seem, ${ }^{128}$ their attitudes may differ little from attitudes of police. ${ }^{129}$ Thus, public expressions of belligerence toward protestors by police union leadership accord with a well-documented culture of hostility on the part of rank-and-file officers toward external challenges. ${ }^{130}$ Several classic studies describe the culture of rank-and-file policing as one of violence and

123. Cf. Fisk \& Richardson, supra note 108, at 759-75 (discussing examples of unionbacked reform).

124. See Rushin, Police Union Contracts, supra note 111, at 1203-05.

125. See William E. Forbath, The Distributive Constitution and Workers' Rights, 72 Ohio St. L.J. 1115, 1140 \& n.98 (2011); Levin, Police Unions, supra note 121, at 1357-58.

126. See Levin, Police Unions, supra note 121, at 1357-58, 1399-98 (noting that reducing problems with policing and the carceral system at large to police unions "would effectively let politicians off the hook").

127. See Alexander, supra note 4, at 210.

128. See Monique Marks, Police Unions and Their Influence: Subculture or CounterCulture?, in Police Occupational Culture: New Debates and Directions 229, 243 (Megan O’Neill, Monique Marks \& Anne-Marie Singh eds., 2007) (“[U]nion leaders know that to hold onto their positions they have to retain the support of their members.").

129. See Levin, Police Unions, supra note 121, at 1338 (noting that criticisms of police unions-in that "they prioritize the interests of their members over the interests of the public at large"-are compelling); Marks, supra note 128, at 231 ("[P] olice unionists ... take their bearings, both structurally and culturally, from within the police organisation.”).

130. See Gregory Pratt \& Jeremy Gorner, Trump Expected to Send New Federal Force to Chicago This Week to Battle Violence, but Plan's Full Scope Is a Question Mark, Chi. Trib. (July 20, 2020), https://www.chicagotribune.com/news/criminal-justice/ct-chicagopolice-dhs-deployment-20200720-dftu5ychwbcxtg4ltarh5qnwma-story.html (on file with the Columbia Law Review); Open Letter from Ed Mullins, Sergeants Benevolent Ass'n, Facebook (June 2, 2020), https://www.facebook.com/sbanypd/posts/3016295705125288 [https:// perma.cc/PTU3-EKF9]. 
hostility toward those who seek to check it. ${ }^{131}$ Updating this literature, Professor Barbara Armacost has shown how the organizational structures of modern police departments incentivize aggressive policing while facilitating systemic misconduct. ${ }^{132}$ Challengers of this characterization argue that a few officers account for much of police abuse. ${ }^{133}$ Regardless, there is little doubt that a culture of silence pervades rank-and-file policing.

Rank-and-file police officers often regard department bureaucracy as illegitimate, unpredictable, and punitive. ${ }^{134}$ They see themselves as convenient scapegoats when aggressive policies-such as stop-and-friskprove unpopular, and police management and elected officials wish to disavow them. ${ }^{135}$ This helps explain rank-and-file police officers' hostility toward political initiatives designed to improve their interactions with citizens. Further, suspicion of bureaucracy and hostility to democratic oversight give rise to a rank-and-file police culture marked by a "rare degree of camaraderie and group loyalty," 136 a tolerance of misconduct, and an intolerance of tattlers. ${ }^{137}$ Thus, officers are reluctant to testify against colleagues and may lie in support of them. ${ }^{138}$ This is not to claim

131. See William A. Westley, Violence and the Police: A Sociological Study of Law, Custom, and Morality 110-21 (1970) ("[T] he police become a close, social group, in which collective action is organized for self-protection and an attack on the outside world.”); Kami Chavis Simmons, The Politics of Policing: Ensuring Stakeholder Collaboration in the Federal Reform of Local Law Enforcement Agencies, 98 J. Crim. L. \& Criminology 489, 49697 (2008) ("The culture of police violence is tightly woven into the institutional fabric of the police organization itself."); David Alan Sklansky, Police and Democracy, 103 Mich. L. Rev. 1699, 1731-36 (2005) [hereinafter Sklansky, Police and Democracy] (surveying classic studies of the group psychology of policing).

132. See Barbara E. Armacost, Organizational Culture and Police Misconduct, 72 Geo. Wash. L. Rev. 453, 455-57, 545-46 (2004) ("Punishing individual cops will not cure the problem of police violence if systemic features of the police organization permit, sanction, or even encourage the officers' violent behavior.").

133. See David Alan Sklansky, Seeing Blue: Police Reform, Occupational Culture, and Cognitive Burn-In, in Police Occupational Culture: New Debates and Directions, supra note 128, at 19, 29 [hereinafter Sklansky, Seeing Blue] ("There is growing recognition that a small subgroup of officers accounts for a large share of police abuse ....").

134. Fisk \& Richardson, supra note 108, at 727.

135. We are grateful to Professor Dan Richman for this point.

136. Fisk \& Richardson, supra note 108, at 727 (internal quotation marks omitted) (quoting Jerome H. Skolnick \& Hames J. Fyfe, Above the Law: Police and the Excessive Use of Force 122 (1993)).

137. See Hans Toch, Police Officers as Change Agents in Police Reform, in Police Reform from the Bottom Up: Officers and Their Unions as Agents of Change 27, 28 (Monique Marks \& David Sklansky eds., 2012).

138. See Gabriel J. Chin \& Scott C. Wells, The "Blue Wall of Silence" as Evidence of Bias and Motive to Lie: A New Approach to Police Perjury, 59 U. Pitt. L. Rev. 233, 256 (1998); Aziz Z. Huq \& Richard H. McAdams, Litigating the Blue Wall of Silence: How to Challenge the Police Privilege to Delay Investigation, 2016 U. Chi. Legal F. 213, 215-17 (describing accounts of retaliation and detailing an incident where the statements of five police officers were inconsistent with video footage of the event in question); Levin, Police Unions, supra note 121 , at 1340 n.29. 
that police culture is static and uniform but that it is often a barrier to reform. ${ }^{139}$

The phenomenon of "de-policing" further illustrates how rank-andfile culture can stymie reforms. Economists Tanaya Devi and Roland Fryer found that when state and federal investigations and consent decrees are prompted by a "viral" incident of deadly force, they cause statistically significant increases in homicide and violent crime. ${ }^{140}$ They hypothesize that when departments are investigated following a violent crime, police respond with an abrupt decrease in policing activity. ${ }^{141}$ Some might infer that law enforcement becomes less aggressive out of fear for their safety when forced to operate under more constraints. ${ }^{142}$ But Devi and Fryer's finding - that consent decrees lead to decreases in violent crime and homicide when they are not prompted by a viral incident-belies this inference.$^{143} \mathrm{~A}$ better framing is that when police are criticized by the public they police, they close ranks and leave that public unprotected. In short, it is democratic supervision that police culture finds particularly intolerable. It follows that public outrage sufficient to overcome the political-will problem may exacerbate the police-culture and police-union problems.

4. Endogenous Policy Tradeoffs. - The structural obstacles thus far addressed-lack of political will, police unions, and police cultureensure that ambitious reform proposals are unlikely to be implemented and even less likely to succeed. Yet some reform proposals overcome these obstacles to become policy. And some of these, on the margins, reduce police violence.

That a policy is only marginally helpful is no reason to condemn it. But many such policies will also have unintended consequences that worsen the pathologies of policing. One must consider these tradeoffs and whether they can be mitigated. For those policies that can overcome structural obstacles to reform, the costs may outweigh the meager benefits.

Consider, for example, the costs of attempting to establish meaningful civilian oversight in Cincinnati. Like many cities, Cincinnati had a civil-

139. Cf. Fisk \& Richardson, supra note 108, at 776-97 (proposing a minority unionism model of police representation designed to give voice to alternative rank-and-file points of view).

140. Tanaya Devi \& Roland G. Fryer Jr., Policing the Police: The Impact of "Pattern-orPractice” Investigations on Crime 4 (Nat'l Bureau of Econ. Rsch., Working Paper No. 27324, 2020), https://www.nber.org/papers/w27324 (on file with the Columbia Law Review).

141. Id. at $2-7$.

142. See Stephen Rushin \& Griffin Edwards, De-Policing, 102 Cornell L. Rev. 721, 73637 (2017) ("Another derivation of the de-policing hypothesis alleges that the introduction of externally mandated legal regulation causes police to be less aggressive, thereby emboldening criminals and increasing crime."); Rushin, Structural Reform Litigation, supra note 85 , at 1412-15 ("Perhaps the most common argument made by de-policing advocates is that [structural reform litigation] will decrease police aggressiveness.").

143. Devi \& Fryer, supra note 140, at 4. 
ian oversight board that lacked the resources to conduct its own investigations and was notoriously ineffective. ${ }^{144} \mathrm{~A}$ high-profile shooting resulted in a rare federal consent decree that required the establishment of the Citizen Complaint Authority, designed to operate independently of the police department. ${ }^{145}$ The contentious political context of this reform, however, appears to have led police officers to decrease their policing of violent crime, leading to a rise in homicide rates in poor neighborhoods of color. ${ }^{146}$ In time, the consent decree expired and the Citizen Complaint Authority became underfunded, ignored, and ineffective. ${ }^{147}$

Perhaps, one might argue, the beneficial effects of the consent decree should be celebrated even if it increased violent crime. But there are additional costs to establishing a toothless civilian oversight board that one must consider. For example, the vast majority of major metropolitan police forces have some type of civilian oversight body. ${ }^{148}$ Yet few such organizations serve as robust accountability mechanisms for the police. ${ }^{149}$ According to a report sponsored by DOJ's Office of Community Oriented Policing Services (COPS), these oversight bodies have failed to foster community trust in police departments. ${ }^{150}$ To be sure, it is theoretically

144. See Sharon Coolidge, Cincinnati's Citizen Complaint Authority: The Director Quit, It's Underfunded \& It's Behind on Cases. Now What?, Cincinnati Enquirer (June 8, 2020), https://www.cincinnati.com/story/news/2020/06/08/cincinnatis-police-oversightboard-short-staffed-behind-cases/5317932002 [https://perma.cc/7FYW-6XZU]; Stephen Manning, Police Review Boards Not Always Effective, Associated Press (Aug. 19, 2001), https://plus.lexis.com/api/permalink/206fbff2-da5d-47b1-9205-103d1bb8926d/?context= 1530671 (on file with the Columbia Law Review) ("Cincinnati . . . has a part-time board with no investigators.").

145. See Memorandum of Agreement Between the DOJ, the City of Cincinnati, Ohio \& the Cincinnati Police Dep't III 35-56 (Apr. 12, 2002), https://www.clearinghouse.net/ chDocs/public/PN-OH-0006-0002.pdf [https://perma.cc/ZMV3-WL5K]; Coolidge, supra note 144; James Pilcher, Cincinnati Agency that Polices the Police Could Get More Funding, WKRC (June 8, 2020), https://local12.com/news/local/cincinnati-citizens-complaintauthority-to-get-bigger-budget-more-investigators [https://perma.cc/6X483RG8] (discussing the history and structure of the agency).

146. See Devi \& Fryer, supra note 140, at 18-19 (finding an increase in Cincinnati homicide rates following the announcement of an investigation).

147. See Coolidge, supra note 144.

148. See Darrel W. Stephens, Ellen Scrivner \& Josie F. Cambareri, Civilian Oversight of the Police in Major Cities 27 (2018), https://www.majorcitieschiefs.com/pdf/news/civilian _oversight_of_the_police_in_major_cities.pdf [https://perma.cc/G6KB-YLRN] ("Seventynine percent of the [Major Cities Chiefs Association] agencies that responded to our survey indicated they have some type of civilian oversight body in their community.”).

149. Udi Ofer, Getting It Right: Building Effective Civilian Review Boards to Oversee Police, 46 Seton Hall L. Rev. 1033, 1034 (2016) (“[G]overnmental agencies with the jurisdiction to oversee police departments[,] . . including . . civilian review boards[,] . . have too often failed when it comes to overseeing police departments."); Samuel Walker, Governing the American Police: Wrestling with the Problems of Democracy, 2016 U. Chi. Legal F. 615, 635 (explaining that structural weaknesses of civilian oversight boards permit "only ... very limited . . . citizen participation in policing").

150. Stephens et al., supra note 148, at 27 ("The question for police is how to engage the community in a way that helps close the gaps that exist between White community 
possible - and an aim of many activist movements-to implement robust civilian oversight boards with sufficient authority to positively influence law enforcement. ${ }^{151}$ But a weak civilian oversight board may be worse than none.

Even when a reform builds community trust, the gains come at a cost. For example, one of the most effective reform strategies is rooted in the procedural justice work of scholars including Professors Tracey Meares and Tom Tyler. ${ }^{152}$ This framework focuses on four factors grounding public acceptance of authority as legitimate: (1) "participation"-whether people can explain their situation to authorities; (2) "fairness" - whether the decisionmaker is neutral, objective, consistent, and transparent; (3) "treat[ment]"-whether legal authorities are rights-respecting and treat people with dignity; and (4) "motivations" - whether legal authorities are sincere and well intentioned. ${ }^{153}$ Accordingly, procedural justice reforms focus on training police officers to act in ways that enhance public perceptions of their legitimacy. ${ }^{154}$ There is growing evidence that such training succeeds in reducing both civilian complaints and uses of force against civilians. ${ }^{155}$

Critics have argued, however, that the procedural justice framework may increase the efficiency of policing as a technology of surveillance and social control of poor communities of color, without reducing its harm. ${ }^{156}$ The result may be a vicious cycle of measured "success" justifying ever higher investment in policing. Procedural justice is ultimately a theory of compliance. By teaching techniques that increase compliance, this

members and racial minorities in confidence and accountability .... The steps that have been taken... have not had much effect on confidence and perceptions of accountability.").

151. See Simonson, Power Lens, supra note 14, at 813-16 (documenting such efforts in several cities, including Chicago, Los Angeles, Nashville, and Washington, D.C.).

152. See Tracey L. Meares, The Good Cop: Knowing the Difference Between Lawful or Effective Policing and Rightful Policing-And Why It Matters, 54 Wm. \& Mary L. Rev. 1865, 1873-76 (2013) (defining "rightful policing").

153. See id.

154. See id.; Tracey L. Meares, The Path Forward: Improving the Dynamics of PoliceCommunity Relationships to Achieve Effective Law Enforcement Policies, 117 Colum. L. Rev. 1355, 1362-63 (2017); Simonson, Power Lens, supra note 14, at 797-99 (citing seminal procedural justice scholarship).

155. George Wood, Tom R. Tyler \& Andrew V. Papachristos, Procedural Justice Training Reduces Police Use of Force and Complaints Against Officers, 117 Proc. Nat'l Acad. Scis. U.S. 9815, 9815 (2020).

156. See Bell, Legal Estrangement, supra note 67, at 2059-64 ("Deploying legitimacy theory and procedural justice ... might even imply ... that the problem of policing is better understood as a result of African American criminality than as a badge and incident of raceand class-based subjugation."); Butler, The System, supra note 77, at 1467-68 ("The problem with reform that is focused on improving perceptions about the police is that it can cloak aggressive policing in enhanced legitimacy, and it has the potential to blunt the momentum for rising up against overcriminalization, wealth inequality, and white supremacy."); McLeod, supra note 35, at 1644 (arguing that the procedural justice approach focuses on a feeling of fairness rather than substantive justice). 
framework better enables police officers to dominate the people they police. As Professor Eric Miller argues, such "good cop" tactics can subvert constitutional rights. ${ }^{157}$ By pretending to value a civilian's experience, an officer can persuade the person to act against their own interests. ${ }^{158} \mathrm{By}$ pacifying those who are wrongfully policed, procedural justice techniques can arguably make policing a more effective technique of racial subordination. ${ }^{159}$

This tradeoff problem extends to other evidence-based measures. Thus, there is widespread national support for the use of body-worn cameras as a tool of police accountability. ${ }^{160}$ But some activists and scholars have cautioned against their uncritical embrace. ${ }^{161}$ First, the gains from body-worn cameras appear to be lower than initially expected. Leave aside the problem that body cameras are frequently turned off when police officers engage in misconduct. ${ }^{162}$ Even when turned on, body cameras have failed to result in police accountability. ${ }^{163}$ The recent killing of George Floyd further suggests that body-worn cameras, when worn, may not deter police misconduct. Balanced against these gains are significant costs. Perspective bias and "motivated cognition" may construct footage taken from an officer's viewpoint as proof the officer was justified in

157. Eric J. Miller, Encountering Resistance: Contesting Policing and Procedural Justice, 2016 U. Chi. Legal F. 295, 344.

158. See id.

159. See Bell, Legal Estrangement, supra note 67, at 2061 (discussing how police reform efforts focused on increasing compliance may reinforce racial subjugation).

160. See Jocelyn Simonson, Beyond Body Cameras: Defending a Robust Right to Record the Police, 104 Geo. L.J. 1559, 1565-66 (2016) [hereinafter Simonson, Beyond Body Cameras] (noting the consensus and describing the wave of jurisdictions that required the use of body cameras); Seth W. Stoughton, Police Body-Worn Cameras, 96 N.C. L. Rev. 1363, 1366-67 (2018) (describing the policy consensus around body-worn cameras and assessing their costs and benefits).

161. See Akbar, Radical Imagination, supra note 35, at 465-66 (noting a concern of advocates "that body cameras do not meaningfully address the power differential between police and the policed"); Marianne Kaba, Opinion, Police "Reforms" You Should Always Oppose, Truthout (Dec. 7, 2014), https://truthout.org/articles/police-reforms-you-shouldalways-oppose [https://perma.cc/BG9S-LE35] [hereinafter Kaba, Police Reforms] (urging resistance to any reforms that are "primarily technology focused"); Reformist Reforms vs. Abolitionist Steps in Policing, Critical Resistance, https://static1.squarespace.com/static/ 59ead8f9692ebee25b72f17f/t/5b65cd58758d46d34254f22c/1533398363539/CR_NoCops _reform_vs_abolition_CRside.pdf [https://perma.cc/JC42-VNWW] [hereinafter Reformist Reforms] (last visited Jan. 14, 2021) (critiquing body-worn cameras).

162. See Simonson, Beyond Body Cameras, supra note 160, at 1567 (noting that a failure to turn on "body-worn cameras may be commonplace in some police departments").

163. See Akbar, Abolitionist Horizon, supra note 46, at 1810-11 ("A recent study was unable to find that body cameras had 'any statistically significant effects' on 'documented uses of force and civilian complaints." (quoting David Yokum, Anita Ravishankar \& Alexander Coppock, Evaluating the Effects of Police Body-Worn Cameras: A Randomized Controlled Trial 22 (2017), https://bwc.thelab.dc.gov/TheLabDC_MPD_BWC_Working_ Paper_10.20.17.pdf [https://perma.cc/57XG-NFH2])). 
harming a civilian. ${ }^{164}$ In addition, activists and scholars have noted that the widespread use of body cameras serves to increase technological surveillance of poor communities of color. ${ }^{165}$

Even police training-the lodestar of many popular reform measures-may have lower gains and higher costs than often assumed. With the exception of procedural justice training, it is questionable whether many popular "reform" based trainings are effective on their own terms. ${ }^{166}$ For example, in the wake of the Ferguson protests, many police departments implemented diversity and implicit bias trainings-including the Minneapolis Police Department, whose officers killed George Floyd. ${ }^{167}$ But there is mounting evidence that such trainings are ineffective at solving the problem of racialized police violence. ${ }^{168}$

Even when police training succeeds on its own terms, the costs may be significant. Abolitionist activists, for example, argue that the assumption that violence is caused by poor training obscures the violence inherent in the police function of coercive social control. Professional development programs can exacerbate mission-creep by justifying assigning additional functions to police. ${ }^{169}$ The supposed professionalism instilled by police training can lead courts to overdelegate discretionary authority

164. See Dan M. Kahan, David A. Hoffman \& Donald Braman, Whose Eyes Are You Going to Believe: Scott v. Harris and the Perils of Cognitive Illiberalism, 122 Harv. L. Rev. 837, 838-41 (2009); Simonson, Beyond Body Cameras, supra note 160, at 1566; German Lopez, The Failure of Police Body Cameras, Vox (July 21, 2017), https://www.vox.com/ policy-and-politics/2017/7/21/15983842/police-body-cameras-failures (on file with the Columbia Law Review) (discussing the Philando Castile case).

165. See Kami N. Chavis, Body-Worn Cameras: Exploring the Unintentional Consequences of Technological Advances and Ensuring a Role for Community Consultation, 51 Wake Forest L. Rev. 985, 988 (2016); Mary Anne Franks, Democratic Surveillance, 30 Harv. J.L. \& Tech. 425, 476 (2017).

166. See supra notes $152-155$ and accompanying text.

167. See DOJ, Civ. Rts. Div., Investigation of the Ferguson Police Department 94-95 (2015), https://www.justice.gov/sites/default/files/opa/press-releases/attachments /2015/03/04/ferguson_police_department_report.pdf [https://perma.cc/DA5C-NU9G] (recommending training on "recognizing and confronting implicit bias and cultural responsiveness"); We Asked 155 Police Departments About Their Racial Bias Training. Here's What They Told Us., CBS News (Aug. 7, 2019), https://www.cbsnews.com/news/ racial-bias-training-de-escalation-training-policing-in-america (on file with the Columbia Law Review) (noting that sixty-nine percent of urban police departments have implicit bias training, including Minneapolis).

168. See Patrick S. Forscher, Calvin K. Lai, Jordan R. Axt, Charles R. Ebersole, Michelle Herman, Patricia G. Devine \& Brian A. Nosek, A Meta-Analysis of Procedures to Change Implicit Measures, 117 J. Personality \& Soc. Psych. 522, 522 (2019) (finding that implicit bias trainings do not change explicit measures of behavior); Robert J. Smith, Reducing Racially Disparate Policing Outcomes: Is Implicit Bias Training the Answer?, 37 U. Haw. L. Rev. 295, 306 (2015) (explaining that implicit bias training is unlikely to reduce incidents of lethal force).

169. See Reformist Reforms, supra note 161 (critiquing training reforms). 
to law enforcement and thereby distort constitutional doctrine. ${ }^{170}$ Thus, training can increase the prestige of police and free them from oversight without improving police behavior.

Finally, any police reform-no matter how effective-may help entrench dysfunctional police bureaucracies by increasing their budgets. ${ }^{171}$ For example, since 1994, the DOJ's COPS program has distributed fourteen billion dollars to local police departments to advance "community policing" initiatives designed to "build[] trust and mutual respect between police and communities." 172 In practice, however, communitypolicing initiatives have had little actual impact. ${ }^{173}$ Professor Rachel Harmon has argued that many federal funding programs for local police departments have resulted in more harmful policing practices, ${ }^{174}$ which are often left unmeasured. ${ }^{175}$

This is not to suggest that no police reforms are worthwhile. For example, all things considered, a police department that embraces procedural justice may be preferable to one that does not. And perhaps federal grants to achieve it are worth the consequences of increasing those departments' budgets. Even when the costs are acceptable, however, the obstacles to reform ensure they will be difficult to mitigate. Such marginal improvements are unequal to the crisis in American policing.

\section{The Case for Disbanding}

The foregoing analysis suggests the problem with incremental police reforms is not their substance. Rather, it is the policing institutions they seek to reform. These institutions help create the structural obstaclespolitical deadlock, organized resistance, and cultural hostility—that block

170. Anna Lvovsky, The Judicial Presumption of Police Expertise, 130 Harv. L. Rev. 1995, 2078 (2017); Anthony O'Rourke, Structural Overdelegation in Criminal Procedure, 103 J. Crim. L. \& Criminology 407, 410 (2013).

171. This concern is central to the abolitionist critique of police reform. See Kaba, Police Reforms, supra note 161 ("Are the proposed reforms allocating more money to the police? ... Are the proposed reforms advocating for MORE police and policing ... ? If yes, then you should oppose them.").

172. About the COPS Office, COPS, https://cops.usdoj.gov/aboutcops [https:// perma.cc/TP7M-QW8B] (last visited Jan. 14, 2021); see also Brian A. Reaves, DOJ, Bureau of Just. Stat., NCJ 248677, Local Police Departments, 2013: Personnel, Policies, and Practices 8 (2015), http://www.bjs.gov/content/pub/pdf/lpd13ppp.pdf [https://perma.cc/BF3PMHT8] (examining the rise in mission statements with a community-policing component between 2003 and 2013).

173. See Seth W. Stoughton, Principled Policing: Warrior Cops and Guardian Officers, 51 Wake Forest L. Rev. 611, 628-30 (2016) (noting that given " $[\mathrm{t}]$ he absence of a functional definition of community policing[,] . . failures of implementation are inevitable”).

174. See Harmon, Real Costs of Policing, supra note 85, at 892 ("[Some] federal programs ... encourage especially harmful policing practices, and they are not designed or evaluated with attention to these harms.").

175. See id. at $897-900$. 
meaningful reforms. Any reform proposal that can overcome these obstacles is likely to do so by appealing to the vested interests of police unions and police management in expanding the footprint of policing. The problem is thus the political entrenchment of policing institutions. The solution to such a problem is not to develop more creative reform solutions. Instead, it is to disentrench the institutions by disbanding them.

Disbanding is not an end in itself, but a mechanism for achieving other aims by removing the structural obstacles that frustrate them. To begin, consider the advantages and limits of eliminating police unions. Just as corporate reorganization can be used to terminate collective bargaining agreements and weaken labor unions, ${ }^{176}$ disbanding can and has been used to weaken police unions. ${ }^{177}$ By terminating collective bargaining agreements, one can eliminate police unions as an obstacle to reform. Many of the union safeguards that perpetuate rank-and-file culture-including seniority rules and union leadership prerogatives-are also eliminated. ${ }^{178}$ Merely eliminating police unions, however, is unlikely to accomplish the goal of transforming rank-and-file culture, which is the product of the institutional design of police departments themselves. ${ }^{179}$ Nor will eliminating police unions reshape other incentives that leave politicians unwilling to engage in serious police reform. ${ }^{180}$

Yet disbanding police departments eliminates not only police unions but also the institutional arrangements that give rise to a rank-and-file police culture hostile to reform. ${ }^{181}$ Disbanding police departments can also permit lawmakers to redesign law enforcement institutions in ways that make them more accountable to elected officials and to the

176. See 11 U.S.C. $\$ 1113$ (2018); Babette A. Ceccotti, Lost in Transformation: The Disappearance of Labor Policies in Applying Section 1113 of the Bankruptcy Code, 15 Am. Bankr. Inst. L. Rev. 415, 417 (2007) ("[T] he strategic use of bankruptcy... [can] bring about broad changes to a business,... including the rejection of collective bargaining agreements, the reduction or elimination of retiree health obligations and transactions to downsize the business ... or facilitate other operational changes to lower labor costs.").

177. Joseph Goldstein \& Kevin Armstrong, Could This City Hold the Key to the Future of Policing in America?, N.Y. Times (July 12, 2020), https://www.nytimes.com/2020/07/12 /nyregion/camden-police.html (on file with the Columbia Law Review) (describing the disbanding of the Camden Police Department as "a political power play meant to break the police officers' union").

178. See Fisk \& Richardson, supra note 108, at 769 ("Today, statements and actions by police unions and rank-and-file officers continue to lend support to the view that police rank-and-file share a monolithic occupational mindset and subculture of paranoia, insularity, and intolerance.").

179. See Sklansky, Seeing Blue, supra note 133, at 28-30.

180. See Levin, Police Unions, supra note 121, at 1399-400 ("[A] critique of police unions that isn't coupled with a deeper critique of governance would do little to shift the balance of power....").

181. See Sklansky, Seeing Blue, supra note 133, at 30-34 (discussing the relationship between institutional design and rank-and-file police culture). 
communities they police. ${ }^{182}$ Moreover, by altering rank-and-file culture, disbanding police departments could arguably reshape the political preferences of a large and influential population of public sector workers. Disbanding the police thus has the potential to eliminate structural obstacles that currently shape law enforcement politics.

Disbanding is thus a tool that can be used to many different ends. By attacking the structural obstacles to reform, disbanding the police could facilitate reforms that are now politically unimaginable. For abolitionists, the ultimate goal is to end policing as we know it and reinvest in alternative regulatory frameworks with greater community control. ${ }^{183}$ But less radical proposals to "defund the police" and invest in other services or community development are also likely to involve disbanding departments to start afresh. Thus, the Minneapolis city council's proposed charter amendment would have disbanded the city's police force and established a "Department of Community Safety and Violence Prevention" with a law enforcement division under its control. ${ }^{184}$ More modestly, some scholars and reformers have called for disaggregating the policing function, transferring many_-but not all_-responsibilities to social workers and other actors. ${ }^{185}$ The city of Berkeley, for example, is considering a proposal to shift responsibility for traffic enforcement from armed police officers to unarmed city workers. ${ }^{186}$ Even some police leaders have voiced support for narrowing the mission of police. ${ }^{187}$ Done to any meaningful degree, however, the task of disaggregating the policing function may require disbanding in order to eliminate surplus policing jobs and circumvent union protections governing conditions of employment. ${ }^{188}$

182. See infra notes 274-280 and accompanying text (discussing reform-era efforts to insulate police departments from political pressures).

183. See Kaba, Police Reforms, supra note 161; see also, e.g., MPD150, Enough is Enough: A 150 Year Performance Review of the Minneapolis Police Department 25-31 (2017), https://www.mpd150.com/wp-content/themes/mpd150/assets/mpd150_report. pdf [https://perma.cc/8WXQ-EX7U] (presenting a comprehensive abolitionist agenda for the Minneapolis Police Department).

184. See Searcey \& Eligon, supra note 25; City Council Advances Proposed Ballot Measure Asking Voters to Create a New Department of Community Safety and Violence Prevention, City of Minneapolis (June 26, 2020), http://news.minneapolismn. gov/2020/06/26/city-council-advances-proposed-ballot-measure-asking-voters-to-create-anew-department-of-community-safety-and-violence-prevention (on file with the Columbia Law Review).

185. See Friedman, Disaggregating, supra note 16 (manuscript at 62-63).

186. See AP, Berkeley Considers Removing Police from Traffic Enforcement, L.A. Times (July 14, 2020), https://www.latimes.com/california/story/2020-07-14/berkeleyconsiders-removing-police-from-traffic-enforcement (on file with the Columbia Law Review).

187. Brady Dennis, Mark Berman \& Elahe Izadi, Dallas Police Chief Says 'We're Asking Cops to Do Too Much in This Country', Wash. Post (July 11, 2016), https:/ /www.washington post.com/news/post-nation/wp/2016/07/11/grief-and-anger-continue-after-dallas-attacks -and-police-shootings-as-debate-rages-over-policing (on file with the Columbia Law Review).

188. See Fisk \& Richardson, supra note 108, at 716-20 (noting that police unions, as currently constituted, represent a significant barrier to the implementation of reform). 
Disbanding can also be a tool for reforms that progressives will find politically objectionable. By destabilizing current political coalitions, disbanding police forces will make law enforcement politics more hotly contested, including by those who favor punitive policies. ${ }^{189}$ In 2011, for example, the Camden Police Department was disbanded under Republican Governor Chris Christie, and control over policing in the majority-minority city was ceded to the majority-white county. ${ }^{190}$ As this example shows, disbanding can also be a tool for politicians hostile to organized labor. Given the antistatist dimensions of the project, one can expect new political constituencies calling to disband police departments. ${ }^{191}$ The uncertain politics of disbanding are certainly cause for caution. Given the severity and entrenchment of America's policing pathologies, however, disbanding may be worth these risks.

Of course, any proposal to disband the police must grapple with the very political obstacles that frustrate incremental police reforms. The key difference, however, is that incremental police reforms require continued political support to remain intact and effective. When that political support wanes, the reform will fall by the wayside, while the concessions made to achieve it may persist. ${ }^{192}$ For example, some recent scholarship argues for the creation of democratically accountable police rulemaking in order to strengthen public control over police departments. ${ }^{193}$ But these scholars also recognize that there are serious public choice obstacles to the sort of legislation necessary to achieve this goal. Even if these obstacles are overcome, police agencies will require sustained, external political or regulatory pressure if they are to meaningfully comply with public rulemaking requirements. ${ }^{194}$ Yet, like a civilian complaint agency imposed after a consent decree, any institutions providing such external oversight are vulnerable to neglect once political support for reform wanes. ${ }^{195}$ By contrast, disbanding advocates could take advantage of a temporary change in

189. See Rappaport, supra note 82, at 714 (explaining that the general consensus among scholars is that "reformers must curb the influence of bureaucrats and redirect power to local communities").

190. Goldstein \& Armstrong, supra note 177.

191. See, e.g., Harry Bruinius, Why Libertarians Are Joining BLM Calls to Defund Police, Christian Sci. Monitor (July 16, 2020), https://www.csmonitor.com/USA/Justice/ 2020/0716/Why-libertarians-are-joining-BLM-calls-to-defund-police [https://perma.cc/K H6Y-UAQP] (reporting that a self-described "hardcore libertarian" Republican candidate for the New Hampshire state senate is running on the platform of defunding the police).

192. See supra notes 95-99 and accompanying text.

193. See Friedman \& Ponomarenko, supra note 14, at 1879-81 ("[O]pening rulemaking to local community participation will bring voices into the process that may have had no outlet thus far."); Slobogin, supra note 31, at 134-37 (discussing the application of administrative law principles, such as notice-and-comment rulemaking, to police agencies). In a subsequent article, Professor Maria Ponomarenko addresses the considerable limits of such an approach, both in terms of feasibility and likely effectiveness. See Maria Ponomarenko, Rethinking Police Rulemaking, 114 Nw. U. L. Rev. 1, 15-20 (2019).

194. Ponomarenko, supra note 193, at 15-44.

195. See supra notes $144-147$ and accompanying text. 
the policy equilibrium to push for reforms that could permanently change the institutional landscape for political contestation over policing. ${ }^{196}$

Yet even if disbanding had broad support, legal impediments would make it very difficult. Disbanding requires political wins at several different levels of government. And jurisdictional overlap means the dissolution of one police force may shift authority to other entrenched law enforcement institutions. This Essay takes up these questions in Part II. For now, it suffices to say that a strategy of disbanding police forces is no less realistic than the hope of achieving incremental reforms adequate to cure the pathologies of American policing, and its benefits are more sustainable over time.

\section{THE LAW OF RESTRUCTURING POLICING}

Ending pathological law enforcement practices may require the wholesale restructuring of law enforcement agencies by means of disbanding. But as this Part explains, the political obstacles to reform are compounded by legal obstacles to restructuring. We make three claims. First, the entrenchment of local law enforcement practices is due in part to the structural entrenchment of local law enforcement agencies. Second, this structural entrenchment results from legally encoding the outcomes of protracted political battles between state and local governments. In presenting these claims, we separately examine the distinct development and legal structure of police departments and sheriffs' offices, showing how both have become similarly entrenched. Distinguishing municipal police and county sheriffs also lays the foundations for our third claim: that prospects for radical reforms are limited by institutional relationships among police departments and sheriffs' offices, and cities and counties. Overall, the legal structure of local law enforcement agencies proliferates decisionmakers who can veto structural reform while empowering these agencies at the expense of the local residents who they are meant to protect and to serve.

\section{A. Police Departments}

The laws governing the organization and operations of local police departments confound popular perceptions of police forces as creatures and instruments of city governments. In reality, local leaders often lack legal authority to disband or restructure their police departments. Here, we outline the multiple sources of law defining the modern police department and show how this complexity impedes structural reform. We then

196. See generally Frank R. Baumgartner \& Bryan D. Jones, Agendas and Instability in American Politics 10 (2d ed. 2009) (setting forth a "punctuated equilibria" theory of policy change by which "long periods of relative stability or incrementalism" are "interrupted by short bursts of dramatic change" that "alter forever the prevailing arrangements in a policy system"). 
show that the difficulty of structural reform arose by design, as a result of strategic choices by earlier reformers to lock in their reforms.

1. Law. - The vast majority of police departments in the United States are political subdivisions of city governments. But the legal sources that underlie their structure and organization include a mix of city ordinances, municipal charters, state law, and state constitutional provisions. These myriad laws at multiple levels limit the authority over police departments of not only local officials but also the state. These limits may prevent disbanding or require that any replacement replicate its predecessor. At the very least, they reveal that the disbanding of police agencies cannot be accomplished through unilateral, uncoordinated action at the state or local level.

Limits on municipal authority can be found at both state and local levels. Municipal charters are important local impediments. ${ }^{197}$ Most municipal police departments are established pursuant to a charter provision. ${ }^{198}$ Chapter 18 of the New York City charter, for example, not only specifies the existence of a police department ${ }^{199}$ but also defines its leadership structure ${ }^{200}$ along with its duties and responsibilities, from keeping the peace and removing nuisances to "suppressing riots, mobs and insurrections" and inspecting businesses and places of amusement. ${ }^{201}$ The Minneapolis City charter contains a similar requirement that the city council "must establish, organize, and otherwise provide for ... a police department," ${ }^{202}$ and requires the city to hire at least seventeen departmental employees for every 10,000 residents. ${ }^{203}$

Depending on how the charter language is worded and the kind of restructuring that is being pursued, city officials may be able to argue that disbanding and replacing the existing police department satisfy their charter duty to establish a police department. Yet given the detailed definition of the responsibilities of the police in most charters, it is more likely that

197. See Nat'l Mun. League, Model City Charter $\$ 4.01 \mathrm{cmt}$. (6th ed. 1964) (explaining that typical city charters will include a provision for a police force); Nestor Davidson, Local Constitutions, 100 Tex. L. Rev. (forthcoming 2021) (manuscript at 1-5), https://ssrn.com/ abstract=3461745 (on file with the Columbia Law Review) ("[C]harters can grant local governments powers and immunities from oversight not shared by non-charter municipalities.... [They] structure public institutions and allocate authority within local governments as well as between municipalities and their residents.").

198. See Nat'l Mun. League, supra note 197, $\$ 45: 9$ ("The office of police officer or police patrol officer was unknown at common law, and wherever such office or place exists it is the creation of statute or municipal charter or ordinance.").

199. See N.Y.C., N.Y., Charter $\S 431$ (2021) ("There shall be a police department the head of which shall be the police commissioner who shall be appointed by the mayor and shall, unless sooner removed, hold office for a term of five years.").

200. See id. $\S \S 431-432$ (specifying, among other things, that there is to be one police commissioner and seven deputies).

201. See id. $\S 435$ (a).

202. See Minneapolis, Minn., Charter $\S 7.2$ (a) (11) (2021).

203. See id. $§ 7.3$ (c). 
radical reforms will require a charter amendment. Such charter amendments are far more difficult to adopt than mayoral orders or city ordinances. ${ }^{204}$ Moreover, because municipal charters are granted to cities by the state, state law usually defines the process for amending charters and sometimes sets substantive limits. ${ }^{205}$ Cities can sometimes initiate the amendment process themselves, either through the city council, a citizen's petition, or the establishment of a charter reform commission. ${ }^{206}$ In most such cases, a final referendum vote by the residents of the city is also required before the amendments can be made. ${ }^{207}$ And, as the recent developments in Minneapolis illustrate, unelected charter commissions can thwart the will of elected city officials to put charter amendments to a referendum. ${ }^{208}$ In the five states where cities are not authorized to adopt charters, their structure and power is defined entirely by state law that can only be amended by the state. ${ }^{209}$ Moreover, in nearly all states, municipal charter provisions must comply with applicable state law. ${ }^{210}$

This brings us then to the second way in which local authority over police disbanding and reform is limited: provisions of state law. Despite their legal status as municipal subdivisions, many police departments were originally created by state law. Moreover, some police departments are entirely controlled by the state. The Kansas City Police Department is one such example, ${ }^{211}$ and the city of St. Louis only regained control of its police department from the state in 2012. ${ }^{212}$ Even in the majority of states where police departments are municipal subdivisions, however, state laws proliferate with respect to policing. In some cases, these state laws may prevent cities from making the charter reforms necessary to disband their

204. See, e.g., Minn. Stat. $\$ 410.12$ (2019) (outlining the process required to amend a city charter). For more information on amending city charters, see 2A Eugene McQuillin, A Treatise on the Law of Municipal Corporations \$ 9:26 (3d ed. 2005).

205. See Minn. Stat. $§ 410.12$. In many states, municipalities can only adopt charters that organize their city in accordance to a specific menu of possible models (e.g., council-mayor, council-manager, etc.). See 2A McQuillin, supra note 204, § 9:7.

206. See 2A McQuillin, supra note 204, \$ 9:29 (discussing various states' procedures for direct amendment of city charters); see also Davidson, supra note 197 (manuscript at 1516).

207. See Davidson, supra note 197 (manuscript at 13).

208. See Herndon, supra note 27.

209. See Davidson, supra note 197 (manuscript at 13).

210. See id. (manuscript at 45-46); see also Paul Diller, Intrastate Preemption, 87 B.U. L. Rev. 1113, 1124-27 (2007). Some states exempt municipal charters from state preemption in matters of "municipal affairs." See, e.g., Traders Sports, Inc. v. City of San Leandro, 112 Cal. Rptr. 2d 677, 683 (1st Dist. 2001).

211. See Mo. Ann. Stat. $\$ 84.350$ (West 2020) (establishing the board of police commissioners for Kansas City and any other city with a population between 300,000 and 700,000 people); id. $\$ 84.360$ ("The governor of the state of Missouri, by and with the consent of the senate, shall appoint the four commissioners provided for in section $84.350 \ldots$. ...).

212. See id $\$ 84.010$ (establishing the St. Louis police force, repealed by an initiative petition in 2012). 
police departments entirely. In others, they may allow disbanding but limit what cities can put in their place.

State laws on policing vary from state to state. But they have become increasingly common, and many were enacted at the request of police unions in order to circumvent local laws. ${ }^{213}$ State laws regulate the recruitment, compensation, promotion, and firing of police officersfrom civil service and pension requirements to mandated disciplinary procedures and bans on municipal residency requirements. ${ }^{214}$ State laws also govern the relationship between police departments and local residents. ${ }^{215}$ Some states limit the power of civilian review boards. ${ }^{216}$ And most states immunize police officers against state legal liabilitysometimes more completely than they immunize cities themselves, while requiring cities to indemnify officers against federal civil rights liability. ${ }^{217}$ Increasingly, states pass laws requiring police departments to assume specific duties and responsibilities. Many states now require police officers to be present at all schools irrespective of the judgment of local school boards. ${ }^{218}$ Local "sanctuary" policies limiting police involvement in federal immigration enforcement have provoked "anti-sanctuary" legislation mandating their participation. ${ }^{219}$

It is still too early to tell whether state laws on policing apply only to existing police departments or also require municipalities to have police departments. But even if disbanding is allowed, such laws place significant constraints on the kinds of alternative policing models a city might implement. More importantly, the prevalence of state laws on policing suggests that radical reform efforts at the local level may be subject to state preemption. After all, we are currently in an era of expanding and

213. See, e.g., Rushin, Police Union Contracts, supra note 111, at 1216 n.119 (listing examples of police union-initiated state legislation); Mike Riggs, Why Firing a Bad Cop Is Damn Near Impossible, Reason (Oct. 19, 2012), https://reason.com/2012/10/19/howspecial-rights-for-law-enforcement-m (on file with the Columbia Law Review) (reporting on police unions lobbying state legislatures to pass "law enforcement bill of rights").

214. See, e.g., N.J. Stat. Ann. §40A:14-147 (West 2020) (regulating procedures and causes for dismissal of a police officer); id. § 40A:14-122.1 (prohibiting municipalities from imposing residency requirements on officers for hiring or promotions).

215. See H.B. 771, 2015 Leg., 435th Sess. (Md. 2015) (requiring the city of Baltimore police department to engage in various "community policing" practices).

216. See, e.g., Fla. Stat. $\$ 112.532$ (2020) (defining the rights of police officers under investigation and placing limits on permissible methods of investigation); Mo. Ann. Stat. $\$ 590.653$ (allowing for the creation of civilian review boards, while limiting what types of evidence they can consider). For an example of how state law can quash the powers of civilian review boards, see D'Agastino v. City of Miami, 220 So. 3d 410, 427-28 (Fla. 2017).

217. See, e.g., Gaca v. City of Chicago, 103 N.E.2d 617, 619 (Ill. 1952) (upholding a state law requiring the indemnification of police officers in cities over 500,000 people). The law is still in force. 65 Ill. Comp. Stat. Ann. 5/1-4-6 (West 2020).

218. See, e.g., S.B. 8. 2020 Leg., Reg. Sess. (Ky. 2020) (requiring schools to have an armed police officer present).

219. See Pratheepan Gulasekaram, Rick Su \& Rose Cuison Villazor, Anti-Sanctuary and Immigration Localism, 119 Colum. L. Rev. 837, 848-50 (2019). 
escalating state preemption of local authority, due in large part to growing partisan splits between cities and states and the willingness of cities to tackle controversial policy issues. ${ }^{220}$ Many state laws on policing were enacted as efforts to preempt local policies, such as residency requirements and civilian review boards. ${ }^{221}$ In response to local disband-andreform efforts, states might preempt such efforts entirely. They might pass laws reinstituting police departments that have been disbanded or reconstituting them as agencies of the state. In fact, even the threat of state preemption may chill action by cautious city officials.

All of this might suggest that radical-reform advocates should turn their attention away from local leaders and instead focus on the state. Cities, after all, are creatures of the state. ${ }^{222}$ They draw their legal authority from state delegations. ${ }^{223}$ Indeed, it is ordinarily understood that just as states are empowered to create cities as legal entities, they are also empowered to dissolve them as they see fit. ${ }^{24}$ This is not to say that convincing a state legislature to pursue disband or reform efforts would be easy. Nonetheless, if states are entitled to dissolve cities, certainly they have the power to disband their police departments. And this would not be the first time that states have pursued this route. The nineteenth century saw many municipal police departments disbanded by state legislature, with state-run police forces instituted in their place..$^{225}$

220. See generally Richard Briffault, The Challenge of the New Preemption, 70 Stan. L. Rev. 1995, 1997 (2018) [hereinafter Briffault, The Challenge] ("[T]he real action today is the new preemption: sweeping state laws that clearly, intentionally, extensively, and at times punitively bar local efforts to address a host of local problems."); Richard C. Schragger, The Attack on American Cities, 96 Tex. L. Rev. 1163, 1165 (2018) (arguing that in passing broad preemptive state legislation, "state legislatures have been motivated by hostility to local regulation").

221. See, e.g., D'Agastino, 220 So.3d at 425-27 (recognizing that Florida's Police Bill of Rights prohibits civilian review boards from imposing disciplinary actions and holding that this law also preempts such boards from issuing subpoenas to compel police officers to testify for investigative purposes); Rochester Police Locust Club, Inc. v. City of Rochester, No. E2019008543, 2020 WL 8028606, at*18 (N.Y. Sup. Ct. May 7, 2020) (holding that state law prohibits the Rochester Police Accountability Board from conducting hearings or disciplining police officers); Briffault, The Challenge, supra note 220, at 2006-07 (detailing a case where the Arizona state government challenged a local ordinance, which regulated police disposal of seized firearms, as preempted by state law); Will Cushman, Many Police Officers in Wisconsin Live Outside the Cities Where They Serve, WisContext (July 9, 2020), https://www.wiscontext.org/many-police-officers-wisconsin-live-outside-cities-where-theyserve (on file with the Columbia Law Review) (reporting that many states have moved away from residency requirements and noting that recent Wisconsin state legislation preempts local governments' ability to impose such a requirement).

222. See Hunter v. City of Pittsburgh, 207 U.S. 161, 178 (1907) ("Municipal corporations are political subdivisions of the state, created as convenient agencies for exercising such of the governmental powers of the state as may be intrusted to them.").

223. See id.

224. See id.

225. See infra notes $248-254$ and accompanying text. 
But despite this history, it is not clear all states are similarly empowered today because a majority of states have adopted constitutional provisions limiting their ability to intervene in local affairs-especially with respect to the structure and organization of local governments. ${ }^{226}$

Some relate to the ability of states to target a single or small subset of cities through state law. Often referred to as bans on "special legislation," these provisions are intended to limit state legislatures to laws applicable throughout the state. ${ }^{227}$ Nearly every state has adopted such a prohibition into their state constitutions. ${ }^{228}$ These provisions limit the ability of the state to disband police departments in a specific city, although disbanding across the state may be possible. Moreover, courts in many states have allowed the state to circumvent the ban on special legislation by passing "general" laws that apply to "classes" that include only one or two cities. For example, Missouri took over police departments in Kansas City and St. Louis by passing a law applicable to cities with populations over $500,000 .{ }^{229}$ Similarly, St. Louis regained control of its police department in 2012 by a law affecting only "cit[ies] not within a county." 230 Nonetheless, other states have more rigorously enforced bans on special legislation. ${ }^{231}$

Other constitutional provisions protecting municipal governments from state interference were adopted in response to the home-rule movement at the turn of the twentieth century. ${ }^{232}$ In some states, these protections are set forth in the constitution. ${ }^{233}$ In other states, such as Ohio, state courts have interpreted constitutional provisions granting local

226. See Gerald E. Frug, The City as a Legal Concept, 93 Harv. L. Rev. 1057, 1115-17 (1980) (noting that while a number of constitutional measures were taken to protect the autonomy of local governments, they have not been very successful); Kenneth E. Vanlandingham, Municipal Home Rule in the United States, 10 Wm. \& M L. Rev. 269, 273$74,277-78$ (1968) (listing states that have some form of home rule).

227. City of Asheville v. State, 665 S.E.2d 103, 121-22 (N.C. Ct. App. 2008) (describing the contours of North Carolina's constitutional ban on special or local laws).

228. See Richard Briffault, Our Localism: Part I-The Structure of Local Government Law, 90 Colum. L. Rev. 1,9 (1990) [hereinafter Briffault, Our Localism] (remarking that, after the Civil War, a wave of state constitutional revisions prohibiting the enactment of special legislation took place); Frug, supra note 226, at 1116 ("One of the most common constitutional amendments was a restriction on state power that gave a state authority to pass only 'general' and not 'special' or local legislation.").

229. See Mo. Ann. Stat. $\$ \S 82.470-82.817$ (West 2020) (statutes applying to cities over 500,000 people); id. $\$ \S 86.010-86.193$ (statutes governing police departments and personnel in cities over 500,000 ).

230. Id. § 84.344.

231. See, e.g., State ex rel. Knisely v. Jones, 64 N.E. 424, 425 (Ohio 1902) (striking down an Ohio act as special legislation); James F. Richardson, Urban Police in the United States 45 (1974) (detailing the intense dispute whereby an Ohio mayor sought a court-enforced invalidation of the special laws at issue); cf. City of Asheville v. State, 794 S.E.2d 759, 772-73 (N.C. 2016) (rejecting state takeover of municipal waterworks as special legislation).

232. See Kenneth A. Stahl, Local Citizenship in a Global Age 78-82 (2020); David J. Barron, Reclaiming Home Rule, 116 Harv. L. Rev. 2255, 2292 (2003).

233. See, e.g., Mo. Const. art. VI, § 22. 
control over "matters of local self-government" to prohibit the state from regulating the "internal government of a municipality, such as . . . the powers, duties, and functions of ... municipal officers." 234 As a result, Ohio's Supreme Court struck down efforts by the state's legislature to regulate how a city selects its police chief ${ }^{235}$ and repeatedly explained that " $[\mathrm{t}] \mathrm{he}$ organization and regulation of its police force ... are within a municipality's powers of local self-government."236

This is not to say that states cannot overcome these limitations. Bans on special legislation may limit or prevent state laws that target a specific police department for disbanding, but some states allow the legislature to overcome that ban if there is a compelling state interest and a reasonable ground for treating a locality differently than others. ${ }^{237}$ Structural homerule protections have been used in states like Ohio to resist state efforts to micromanage personnel matters with respect to policing ${ }^{238}$ but might perhaps apply differently to wholesale restructuring of law enforcement responsibilities. More importantly, while the vast majority of states have adopted bans on special legislation and home rule, ${ }^{239}$ only a few state courts have considered the effect of these limits on state efforts to restructure municipal police departments. Thus, even if some states can circumvent special legislation and home rule concerns to disband and reform municipal police departments, it is not clear they can do so unilaterally.

In short, when it comes to municipal police, disband-and-reform efforts will likely require coordination at both the state and local levels. Legal limitations on both state and local actors mean that neither are likely to be able to implement such reforms unilaterally, even less so in the face of active resistance at either level. Even with cooperation and coordination, reformers may need to navigate a number of different legal processes, from charter reforms to constitutional amendments. All of this is to say that radically restructuring a police agency is procedurally complex.

234. See, e.g., Lorain St. R.R. Co. v. Pub. Utils. Comm'n, 148 N.E. 577, 580 (Ohio 1925) (Marshall, C.J., concurring).

235. State ex rel. Lynch v. City of Cleveland, 132 N.E.2d 118, 121 (Ohio 1956) (holding that a city is not subject to state law in how it selects its police chief).

236. Harsney v. Allen, 113 N.E.2d 86, 88 (Ohio 1953).

237. See, e.g., Village of Chatham v. County of Sangamon, 814 N.E.2d 216, 225-26 (Ill. App. Ct. 2004); Williams v. Blue Cross Blue Shield of N.C., 581 S.E.2d 415, 425 (N.C. 2003).

238. See supra notes 234-236; see also Springfield Command Officers Ass'n v. City Comm'n for Springfield, 575 N.E.2d 499, 501-03 (Ohio Ct. App. 1990) (holding that a city charter prevailed over a state law governing the promotion of police officers).

239. See, e.g., Dale Krane, Platon N. Rigos \& Melvin B. Hill Jr., Home Rule in America: A Fifty-State Handbook 14 (2001) (noting that home rule was adopted in forty-five states, though quite limited in some); Lyman H. Cloe \& Sumner Marcus, Special and Local Legislation, 24 Ky. L.J. 351, 351 (1936) ("With the exception of four New England States the constitutions of all others contain restrictions upon local and special legislation." (footnote omitted)). 
These legal obstacles may help explain why police reform efforts for most of the twentieth century have been less radical.

2. History. - The preceding section identifies obstacles to disbanding local police agencies resulting from their entrenchment by state and local law. But how did we get to the point where a municipal department is so insulated from structural reform? No comparable constraints limit the power of Congress over administrative agencies, including those involved with federal law enforcement. ${ }^{240}$ Nor are state departments insulated to the same extent. ${ }^{241}$

To understand the peculiar nature of police departments then, we must delve into the history of their formation and reformation. This history reveals that policing and police departments have been mired in state-local conflicts from the start. ${ }^{242}$ These conflicts were also part of broader struggles over control of cities-not only when cities lost their legal independence in the nineteenth century and became "creatures of the state" but also when they regained some of that autonomy as a result of the home-rule movement. Moreover, because both states and localities sought to entrench their respective gains, each reform made further reform harder.

The origins of local police departments were not entirely local. Few were actually created entirely by the cities themselves. In some cities, police departments were formed only after authorization by the state. ${ }^{243}$ The nation's first police department was established in Boston, after state authorization in 1838. ${ }^{244}$ In others, the city police department replaced police forces that had already been established by the state. Pennsylvania created a county-wide police force that served Philadelphia and its surrounding communities in 1850 before creating the Philadelphia police

240. For example, the creation of the Department of Homeland Security meant the abolition of the Immigration and Naturalization Service. Homeland Security Act of 2002, Pub. L. No. 107-296, § 471(a), 116 Stat. 2135, 2205 (codified as amended at 6 U.S.C. § 291 (2018)).

241. See, e.g., Suermann v. Hadley, 193 A. 645, 658 (Pa. 1937) ("The Legislature may abolish or reorganize municipal or other agencies of government, whether they be cities, boards, or commissions, and the reorganization may be such as to require an effective abolishment of offices ....").

242. See, e.g., People ex rel. Wood v. Draper, 15 N.Y. 532, 534-35 (1857) (challenging a state law that replaced the New York City municipal police with a state-run police department); David R. Johnson, Policing the Urban Underworld: The Impact of Crime on the Development of the American Police, 1800-1887, at 25-34 (1979) (illustrating the conflict between Philadelphia and the Pennsylvania legislature over how the city should be policed).

243. Mayor of Balt. v. State ex rel. Bd. of Police of Balt., 15 Md. 376, 376 (1860) (upholding the constitutionality of the law creating the Baltimore City Police Department).

244. Edward H. Savage, A Chronological History of the Boston Watch and Police, from 1631 to 1865 , at 77-78 (2d ed. 1865); Olivia B. Waxman, How the U.S. Got Its Police Force, Time (May 18, 2017), https://time.com/4779112/police-history-origins [https://perma.cc /8EFR-YJB9] ("The first publicly funded, organized police force with officers on duty fulltime was created in Boston in 1838."). 
department in $1854 .{ }^{245}$ Some police departments were created entirely by state law. New York City had been debating the creation of a police department for a number of years when the state legislature imposed one in 1844 , over resistance by the city. ${ }^{246}$ Five years later the NYPD would be added to the city's charter. ${ }^{247}$

It was not clear in the nineteenth century that municipal police departments would remain municipal. Indeed, the earliest instances of police disbanding in America were at the hands of the state and in many cases only a few years after the police departments were first established. State legislatures abolished the Baltimore police department in $1860^{248}$ and the St. Louis and Chicago police departments in $1861 .{ }^{249}$ In each case, the disbanding was followed by the creation of a new police force, sometimes serving a larger jurisdiction than the city, but in all cases under the direct control of the state. ${ }^{250}$ The mold for this kind of radical restructuring was cast by the first of such disbanding, which took place in New York. ${ }^{251}$ A little more than a decade after the NYPD was established, the state legislature passed a law disbanding it in 1857, replacing it with the Metropolitan Police Department with jurisdiction over not only New York City but also surrounding areas in Kings, Westchester, and Richmond counties. ${ }^{252}$ It was put under the control of a new board of commissioners whose membership was composed entirely of gubernatorial appointees. ${ }^{253}$ This time, the opposition by the city was not just political. The NYPD not only refused to disband but also violently clashed with the newly formed Metropolitan Police. ${ }^{254}$

The reasons behind this early turmoil over policing were both partisan and ethnic. Urbanization gave rise to partisan divisions between state

245. Johnson, supra note 242, at 34-35; Joseph F. Spillane \& David B. Wolcott, A History of Modern American Criminal Justice 13 (2013).

246. See Johnson, supra note 242, at 26; George J. Lankevich, American Metropolis: A History of New York City 84 (1998).

247. Wood, 15 N.Y. at 534-35.

248. Mayor of Balt., $15 \mathrm{Md}$. at 454-55; Johnson v. Mayor of Balt., 161 A.3d 95, 101 (Md. Ct. Spec. App. 2017) ("When the Democrats won control of the state legislature in the 1859 elections, the first order of business was to seize state control of the Baltimore Police Department.... The Court of Appeals affirmed the constitutionality of this State takeover....").

249. See Smith v. State, 152 S.W.3d 275, 278 (Mo. 2005) (“[T] he general assembly has expressly prohibited the City of St. Louis and its officials from presuming to exercise authority or control over . . . the Police Department."); Sam Mitrani, The Rise of the Chicago Police Department: Class and Conflict, 1850-1894, at 48-51 (2013) ("The bill establishing the Chicago Police Board removed control of the force from elected municipal officials and put it in the hands of the governor and an appointed group of experts.").

250. See supra notes 247-249 and accompanying text.

251. See Wood, 15 N.Y. at 535; Lankevich, supra note 246, at 101.

252. See supra note 251 and accompanying text.

253. See supra note 251 and accompanying text.

254. See Eric H. Monkkonen, Police in Urban America, 1860-1920, at 42-43 (1981); Richardson, supra note 231, at 39. 
and city governments. ${ }^{25}$ These partisan divides were exacerbated by ethnic divisions: While the composition of state governments was largely American-born and Protestant, city officials were increasingly those who were elected by Catholic immigrants. ${ }^{256}$ From this perspective, state reformers believed municipal police departments were too accommodating to immigrant lifestyles and had become corrupt patronage operations for urban political machines. ${ }^{257}$ For urban residents, however, ward control of police precincts meant that the police were often seen as representatives of their neighborhood, and for many immigrant newcomers, police service offered an economic steppingstone into the middle class. ${ }^{258}$ Attendant to these conflicts, both parties disbanded city forces. ${ }^{259}$ In New Jersey, for example, a Democratic-controlled legislature took over the Republican-controlled Newark police department. ${ }^{260}$ When Republicans gained control of the state legislature in 1871, they responded by taking over the Democratic-controlled police department in Jersey City. ${ }^{261}$

These partisan and ethnic conflicts over policing spilled over into broader jurisprudential battles over the legal identity of the American city. Indeed, the emergence of the municipal police department coincided with a pivotal period in the legal development of cities. During the midnineteenth century, the legal status of cities transitioned from corporations to political subdivisions of the state. ${ }^{262}$ Then, during the late nineteenth century, the home-rule movement led many states to reestablish some of the independent authority of cities and limit the state's role in municipal affairs. ${ }^{263}$ Both of these developments played an important role in the legal construction of the modern city. They are also both intertwined with policing. ${ }^{264}$

255. Johnson, supra note 242, at 22, 26 (noting that rising racial and religious tensions led to mob violence against minorities).

256. See David R. Berman, Local Government and the States: Autonomy, Politics and Policy 44-45 (2d ed. 2020); Robert M. Fogelson, Big-City Police 41-45 (1977).

257. See Berman, supra note 256, at 45-47 ("[R] eformers . . . identified with the local branches of the major political parties- the 'machines' headed by 'party bosses' that, with the help of immigrant voters, flourished in many cities."); Fogelson, supra note 256, at 43, 91; Johnson, supra note 242, at 22-26 (outlining a New York state investigation, motivated by political battling between the state and city, which revealed corruption and widespread power wielded by the city alderman).

258. See Fogelson, supra note 256, at 90.

259. See Berman, supra note 256, at 46-47 (noting that where there was a partisan split between state and city governments, "state lawmakers commonly set out to destroy the local party organizations[,] ... often br[inging] direct action against cities where the wrong party was in control").

260. See id.

261. See id.

262. See id. at 52-53 (describing the rise of Dillon's rule and the "state creature" doctrine).

263. See id. at 50-52.

264. See id. at 47-48 (discussing state efforts to take over police departments and the motivation for such takeovers). 
Litigation over the various state takeovers of municipal police departments played a central role in establishing cities as mere "creatures of the state." As Professor Hendrick Hartog argues, the decision by the New York Court of Appeals in Wood v. Draper-which upheld the replacement of the NYPD with the Metropolitan police-"inaugurated a new period in the institutional history of the city." 265 Prior to that, it was widely assumed that the legislation affecting New York City should be passed with the city's consent. ${ }^{266}$ But when the court upheld not only the state's disbanding of the NYPD but also the appropriation of the city's real property and funds to support the operations of the Metropolitan Police, any semblance of municipal autonomy from state dominance evaporated. ${ }^{267}$ Similarly in Missouri, the state supreme court made clear that "protection of life, liberty, and property, and the preservation of the public peace and order" is a governmental power possessed solely by the state, and which the state can choose to delegate or revoke as it sees fit. ${ }^{268}$ Moreover, this includes the power to compel cities and counties to provide funding demanded by the state-controlled Metropolitan Police. ${ }^{269}$

On the other hand, these takeovers fueled the home-rule movement. ${ }^{270}$ To be sure, it was not initially clear that home rule would cover policing. Missouri, the first state to adopt a home-rule provision, specifically exempted the power to establish a police force. ${ }^{271}$ But in the states that followed, police takeovers in the mid-nineteenth century motivated states to amend their constitutions to prohibit special legislation and the transfer of municipal functions to state-controlled commissions. ${ }^{272}$ Furthermore, the emphasis of home rule advocates on the power of cities to frame charters was spurred in large part by states using their power to preempt city charters for the purpose of disbanding municipal police departments. ${ }^{273}$ If these limitations now impede state efforts to disband municipal police departments unilaterally, this history shows that this result was intended.

265. Hendrik Hartog, Public Property and Private Power: The Corporation of the City of New York in American Law 1730-1870, at 238 (1983).

266. Id.

267. Id.

268. State ex rel. Hawes v. Mason, 54 S.W. 524, 529 (Mo. 1899).

269. See id.; State ex rel. Police Comm'rs of St. Louis v. Cnty. Ct. of St. Louis Cnty., 34 Mo. 546, 570-71 (1864); see also State ex rel. Campbell v. Bd. of Police Comm'rs of St. Louis, 88 Mo. 144, 145 (1885) (holding that the Board of Commissioners could not remove the chief of police without cause, as this would "thwart the clearly expressed intent of the general assembly").

270. See Berman, supra note 256, at 49-52.

271. See Mo. Const. art. IV, § 53 (1875); Berman, supra note 256, at 52.

272. See, e.g., Briffault, Our Localism, supra note 228, at $9 \&$ n. 17.

273. See, e.g., Richardson, supra note 231, at 45 (describing how home rule advocates in Ohio overturned a state law dictating the governing structure of police and other public safety departments, and pushed through a constitutional amendment that enabled cities to adopt their own governing structure through municipal charters). 
The legal entrenchment of these outcomes set the template for subsequent reforms. Thus, when the progressive reformers of the early twentieth century turned their attention to policing, they codified their gains in ways that made subsequent reforms harder to implement. Following in the footsteps of the home-rule movement, progressive reformers did not seek to reenact the state takeovers of the nineteenth century. ${ }^{274}$ Yet, motivated by the same concerns, they turned to charter amendments to insulate police departments from local political influence, especially the ward leaders that controlled at the precinct level. ${ }^{275}$ They also turned to state law to ensure that police officials were not drawn from the immigrant neighborhoods that they were charged with patrolling. ${ }^{276}$ As reflected in the Wickersham Commission's Report, these reformers believed that the "chief evil" of local law enforcement was the public's desire to control the police. ${ }^{277}$ Control of police departments thus was stripped from multimember boards and turned over to a single chief or commissioner under the direct control of the mayor, elected by the city as a whole. ${ }^{278}$ Precinct lines were redrawn so that they were no longer conterminous with ward districts. ${ }^{279}$ State laws on policing also proliferated, with the implementation of civil service requirements, mandated city-funded pensions, and later, the elimination of municipal residency requirements. ${ }^{280}$

The policing reforms of the Progressive Era contributed to today's policing pathologies: the lack of local political accountability, the demographic disparities between police and the populations they patrol, and the outsized influence of police unions. But progressive reforms also shaped the legal structure that entrenches those pathologies. To expand the influence of at-large city officials over ward representatives, progressive reformers restructured the accountability of police departments through the city charter. To exclude local leaders from staffing decisions, progressive reformers passed state laws on hiring, promotion, and termination of police officers. At the same time, progressive reformers were suspicious of the state as well, and rejected total state or national control. What emerged was a legal structure that broadly distributed the power to veto reform. This empowered police departments, a result that aligned with the progressive reformers' identification of a professional and apolitical police

274. See Fogelson, supra note 256, at 91-94.

275. See id. at 42.

276. See id. at 91-94 (noting that reformers, hostile to "immigrant life-styles," successfully lobbied states to exercise more control over local policing).

277. Friedman \& Ponomarenko, supra note 14, at 1859 (quoting Nat'l Comm'n on L. Observance \& Enf't, Report on Police 1-6 (1931) ("Wickersham Commission" Report)); see also Livingston, supra note 56, at 565-66 (1997) (discussing the implementation of civil service systems aimed to counteract the "corrupting" effects of local politics).

278. See Fogelson, supra note 256, at 89.

279. See id. at 43 .

280. See id. at $75-89,102-105,164$. 
force with the rule of law. This immunized police departments against dissolution and insulated them from democratic control.

\section{B. Sheriffs' Offices}

For much of the United States, policing falls under the jurisdiction of county sheriffs. Sheriffs' offices employ about a quarter of all sworn (nonfederal) officers in the United States. ${ }^{281}$ Approximately forty percent of Americans live in communities where sheriffs' offices are the sole local law enforcement body. ${ }^{282}$ These communities tend to be unincorporated places within counties, which in many states include townships and towns. But the role of the sheriff often extends beyond these places. Approximately sixty-five percent of municipalities and towns do not have their own police departments and contract with the county sheriff's office for policing services. ${ }^{283}$ Even where municipal police departments exist, sheriffs often share concurrent jurisdiction in the cities they serve. ${ }^{284}$ As protests in support of police reforms have spread, the focus in many places is increasingly centered on sheriffs' offices. ${ }^{285}$ This section outlines the legal structure and historical development of sheriffs' offices. While police and sheriffs serve similar law enforcement roles today, and are both equally resistant to structural reforms, the sheriff and the police arrived at this point from dramatically different directions.

1. Law. - How are sheriffs different from the police? The most significant difference is that sheriffs are "constitutional offices" in nearly

281. See supra note 18 and accompanying text.

282. Estimated from the percentage of Americans who live in unincorporated places, which is about thirty-seven percent. See Cohen et al., supra note 18, at 2 fig.1 (estimating that $62.7 \%$ of the population in the United States lives in incorporated places).

283. See Steven G. Brandl, Police in America 51 (2018); Soraya K. Kawucha, SheriffsThe Other Police 140, 148, 155, 165 (Dec. 2014) (Ph.D. dissertation, Sam Houston State University) (Proquest), https://search.proquest.com/docview/1663996999 (on file with the Columbia Law Review) ("[Sheriffs] provide law enforcement in unincorporated areas and those cities that contract for services, run jails and detention centers, serve civil processes, hold sheriff's sales, and protect courts.").

284. See David N. Falcone \& L. Edward Wells, The County Sheriff as a Distinctive Policing Modality, 14 Am. J. Police 123, 129 (1995) ("By law, the sheriff's jurisdiction generally includes everything within the county. The overlapping jurisdictions with municipalities within the county have clear potential for political conflicts and legal ambiguities.")

285. See, e.g., Cheryl Corley, Policing Reform, Civilian Oversight and More: After Months of Protest, Voters Decide, NPR (Oct. 31, 2020), https://www.npr.org/2020/ 10/31/928212758/policing-reform-civilian-oversight-and-more-after-months-of-protestvoters-decid (on file with the Columbia Law Review) (describing various proposed changes to sheriffs' offices by state); Campbell Robertson, What Black Lives Matter Has Revealed About Small-Town America, N.Y. Times (July 15, 2020), https:/ /www.nytimes.com/2020/07/15/us/ black-lives-matter-protests-small-towns.html (on file with the Columbia Law Review) (last updated Nov. 7, 2020) (describing how small-town protests have focused on demanding police reform in City Council meetings). 
all states where they serve a law enforcement function. ${ }^{286}$ In other words, state constitutions usually require the selection of a sheriff and specify their jurisdiction and authority. ${ }^{287}$ This means that any effort to abolish the office of the sheriff will likely require an amendment to the state constitution.

The constitutional standing of sheriffs also structures their relationship with county governments. It is common today to refer to sheriffs as "county sheriffs." Most are elected by county residents, ${ }^{288}$ and their jurisdiction is generally the same as that of county governments. ${ }^{289}$ Nonetheless, sheriffs operate independently of county governments and are generally insulated from county control. ${ }^{290}$ As a historical matter, the office of the sheriff in many states preceded the creation of county governments as we now know them. ${ }^{291}$ As a result, the two are often distinguished as a matter of law. Courts in many states treat "sheriffs and deputy sheriffs [as] state officials, not local government officials." ${ }^{292}$ Their "duties are determined by state law, not locally enacted ordinances." 293 Even in states that do recognize sheriffs as county officials, courts often make clear that they are not subject to the control of the county governments. ${ }^{294}$ Thus, in Illinois, the courts explain that "sheriffs answer

286. See James Tomberlin, Note, "Don't Elect Me": Sheriffs and the Need for Reform in County Law Enforcement, 104 Va. L. Rev. 113, 123 (2018); see also Roop v. Whitt, 768 S.E.2d 692, 695 (Va. 2015) ("By contrast, constitutional officers, including sheriffs, are creations of the constitution itself.").

287. See, e.g., Cal. Const. art. XI, § 4; Colo. Const. art. XIV, § 8; Del. Const. art. III, § 22; Fla. Const. art. VIII, § 1(d); Ga. Const. art. IX, § 1, II III; Ill. Const. art. VII, § 4; N.C. Const. art. VII, § 2; Pa. Const. art. IX, § 4; Tex. Const. art. V, § 23.

288. Falcone \& Wells, supra note 284, at 125, 127. One exception is the State of Indiana, where the legislature eliminated elections for sheriffs in 1971 and replaced them with an appointment system. Kawucha, supra note 283, at 141 .

289. See Falcone \& Wells, supra note 284, at 129.

290. See Tomberlin, supra note 286, at 129 ("Contrary to the perception of the sheriff as an officer of the county accountable to county citizens-subject, perhaps, to too much local control-the sheriff's institutional features actually insulate him almost entirely from attempts by local officials to hold him accountable.").

291. See, e.g., Julian P. Boyd, The Sheriff in Colonial North Carolina, 5 N.C. Hist. Rev. 151, 152 (1928) (noting that the first North Carolina sheriff was appointed in 1739). Sheriffs have existed in the United States since at least 1634. Kawucha, supra note 283, at 80. Indeed, in many states, the office of the sheriff even predates the creation of the state itself. See id. at 89 ("For example, Ohio appointed its first sheriff in 1788, and shifted to an elected sheriff once it became a state in 1803.").

292. Prince George's County v. Aluisi, 731 A.2d 888, 895 (Md. 1999).

293. Id.

294. See Askew v. Sheriff of Cook Cnty., 568 F.3d 632, 636 (7th Cir. 2009) (“[T]he Sheriff is an 'independently elected county officer and is not an employee of the county in which the sheriff serves." (quoting Carver v. Sheriff of LaSalle Cnty., 787 N.E.2d 127, 136 (Ill. 2003))); Lawson v. Lincoln County, 664 S.E.2d 900, 902 (Ga. Ct. App. 2008) (explaining that while the sheriff is a county officer, the role and its duties are determined by the state legislature); Prince George's County, 731 A.2d at 895 ("[T] he duties of the sheriffs are those 
to the electorate of the county from which they are elected, and not the county board." 295 All this sets sheriffs apart from police, which were created as administrative subdivisions of city governments. This is also why county charters and ordinances rarely address the duties or organization of sheriffs' offices in any significant detail. ${ }^{296}$ Indeed, the few instances where county sheriffs' offices are construed as county offices are in the context of liability and to the detriment of the county. ${ }^{297}$

The one area where the power of county boards most directly intersects with the sheriff is with respect to funding. But even here, the county's role is probably better understood as an obligation rather than a source of authority. ${ }^{298}$ In many states, the duty to fund sheriffs and their department is mandated by state law. ${ }^{299}$ And in a number of states, the discretion of the county board in doing so is limited. ${ }^{300}$ Some states, like

prescribed by the common law, the enactments of the General Assembly, and the rules of the Court of Appeals.").

295. See Carver v. Sheriff of La Salle Cnty., 787 N.E.2d 127, 136 (Ill. 2003); Roop v. Whitt, 768 S.E.2d 692, 695 (Va. 2015) ("[Sheriffs'] compensation and duties are subject to legislative control, but only by state statute and not local ordinance.").

296. An additional reason for this is that unlike cities, county charters are relatively uncommon and exist usually only in the few states that have granted home rule to counties and among the even smaller number of counties that have elected to adopt a home-rule charter. See David K. Hamilton, Governing Metropolitan Areas: Response to Growth and Change 259-60 (Richard D. Bingham series ed., 1999) (estimating that that less than ten percent of counties authorized to adopt a home-rule charter have done so); Krane et al., supra note 239, at 394, 477 tbl.A2 (surveying county government home rule). For the vast majority of counties, their organization and structure are also specified by state law. See David Rusk, Cities Without Suburbs 93-94 (2d ed. 1995). Another reason is that state law usually grants sheriffs broad authority with respect to the organization of their department, including the power to appoint and hire deputies. Carver, 787 N.E.2d at 137 (citing 55 Ill. Comp. Stat. Ann. 5/3-6008 (West 2019)).

297. See Braillard v. Maricopa County, 232 P.3d 1263, 1269 (Ariz. Ct. App. 2010) (holding that because the state legislature has not authorized sheriffs' offices to be sued as a "jural entity," civil rights suits against them should be raised against the county).

298. See Falcone \& Wells, supra note 284, at 126 ("Where the sheriff's office is constitutionally mandated, it cannot simply be abolished, have its powers and responsibilities reduced, or have its personnel decisions made by county boards or commissioners. Although they nominally may control the budget for the sheriff's office, county or state executives cannot dictate sheriff's office policy ....").

299. See Tomberlin, supra note 286, at 133 ("Limits on a county government's budgetary power are inherent in the sheriff's constitutional status: no county action may prevent the sheriff's execution of statutory or constitutional mandates, and budgetary restrictions are often seen as impermissible attempts by county government to control the sheriff's operations." (footnotes omitted)).

300. See, e.g., Ala. Code $\$ 45-37-230$ (2020) (mandating a salary of $\$ 160,000$ a year for the sheriff of Jefferson County and cost-of-living adjustments); Md. Code Ann., Cts. \& Jud. Proc. § 2-316(b) (West 2020) (fixing the salary of the Sheriff of Baltimore City); Alachua County v. Darnell, 301 So.3d 1027, 1029 (Fla. Dist. Ct. App. 2019) (holding that the county is required to fund the sheriff and that the sheriff's constitutional duties allow the sheriff to transfer funds between objects without the county's approval after the budget is approved); Chaffin v. Calhoun, 415 S.E.2d 906, 908 (Ga. 1992) (allowing the county to make some 
Maryland and Alabama, specify the amount of county funding that must be provided and do so on a county-by-county basis. ${ }^{301}$ In others, state courts have limited the influence that county boards can exercise over the sheriff through the appropriations process. ${ }^{302}$ In Florida, for example, an appellate court recently held that once a budget proposed by a sheriff has been approved, there is no further obligation on the part of the sheriff to spend the appropriated funds in accordance with the approved budget. ${ }^{303}$ As the court explained, the constitutional and statutory independence of the sheriff means that the county's duty to appropriate funds cannot be used as a means of controlling the internal operations of the sheriff's office, which belongs "uniquely to the Sheriff as the chief law enforcement of the county." 304

The control that county boards of supervisors can exercise over sheriffs and sheriffs' offices through the budgeting process is further undermined by the revenues they receive from noncounty sources. ${ }^{305}$ Sheriffs directly contract with cities to provide law enforcement services in return for payments from those cities. ${ }^{306}$ They operate jails, and often build excess capacity in order to provide beds to other jurisdictions or the federal government in return for monetary reimbursements. ${ }^{307}$ In some states, they are constitutionally or statutorily authorized to contract with private business to provide them with prison labor. ${ }^{308}$ All of this is in addition to the revenue received from asset forfeiture programs from those arrested for crimes, which police departments take advantage of as well. ${ }^{309}$ As section II.B.2 describes, the revenue model of sheriffs' offices has historical linkages to the fee-for-service model used to compensate sheriffs in the eighteenth and nineteenth centuries.

budgetary cuts to the sheriff's office, but not so much that the sheriff is divested of their law enforcement powers and duties).

301. See Ala. Code § 45-37-230; Md. Code Ann., Cts. \& Jud. Proc. § 2-316.

302. See Alachua County, 301 So.3d at 1029.

303. See id.

304. Weitzenfeld v. Dierks, 312 So. 2d 194, 196 (Fla. 1975).

305. Falcone \& Wells, supra note 284, at 130 ("As a result of historical development, monetary compensation for the sheriff has often come from the collection of fees for services provided ....").

306. See, e.g., Gary J. Miller, Cities by Contract: The Politics of Municipal Incorporation 22-26 (1981) [hereinafter Miller, Cities by Contract] (noting that the Los Angeles County Sheriff's office contracted extensively with the surrounding municipalities throughout the second half of the twentieth century); Kawucha, supra note 283, at 152, 178-81 (citing examples of sheriff departments in Nevada, California, and Virginia contracting with cities and counties).

307. See, e.g., Kawucha, supra note 283, at 174.

308. See, e.g., Cal. Const. art. XIV, $§ 5$ (authorizing the county sheriff to enter into contracts to provide inmate labor to external organizations).

309. See Taken: How Police Profit from Seized Property, Pulitzer Ctr., https://taken.pulitzercenter.org [https://perma.cc/T5K7-C6F6] (last visited Jan. 14, 2021) (data visualization of civil asset forfeiture). 
Given the fact that many courts construe sheriffs as state officials, one might presume that the lack of county authority over sheriffs is offset by that of the state. In many cases, that is true. ${ }^{310}$ Many state constitutions do not set forth all the powers and duties of the sheriff directly, instead delegating that power to the state legislature. ${ }^{311}$ Moreover, state constitutions and state laws often set out the process by which sheriffs can be removed, and in most cases, that process empowers state officials-whether the Governor, the Attorney General, or the state legislature. ${ }^{312}$ Of course, to abolish the office of the sheriff entirely in most cases still requires a constitutional amendment. This is how the offices of "high sheriff" were eliminated in Connecticut through a ballot measure in 2000, which also transferred the employees of sheriffs' departments to the state Judicial Department. ${ }^{313}$

But while states have far more authority over sheriffs than county governments do, the constitutional status of sheriffs also provides them with some protection from state control. Not only is the office immune from legislative abolition, but in many states, its powers cannot be legislatively modified ${ }^{314}$ or eliminated ${ }^{315}$ because they are defined by common law. ${ }^{316}$ Thus, in Beck v. County of Santa Clara, a California court

310. See, e.g., Cal. Const. art. 5, § 13 ("It shall be the duty of the Attorney General to see that the laws of the State are uniformly and adequately enforced. The Attorney General shall have direct supervision over every district attorney and sheriff and over such other law enforcement officers as may be designated by law ...."); Mass. Const. art. XIX, amended by Mass. Const. amend. art. XXXVI ("[The Legislature] shall prescribe, by general law, for the election of sheriffs ....").

311. See, e.g., Colo. Const. art. XIV, § 8.5; Tex. Const. art. V, § 23; Va. Const. Art. VII, $\S 4$; Lawson v. Lincoln County, 664 S.E.2d 900, 902 (Ga. Ct. App. 2008) (noting that the sheriff is subject to the control of the state legislature); Prince George's County v. Aluisi, 731 A.2d 888, 894 (Md. 1999) (stating that the Maryland Constitution leaves the definition of sheriffs' powers, primarily, to the legislature).

312. See, e.g., Ala. Const. art. VII, § 174 (" $[S]$ heriffs[] may be removed from office for any of the causes specified in Section 173 or elsewhere in this constitution, by the supreme court, or under such regulations as may be prescribed by the Supreme Court of Alabama or law.”); Cal. Const. art. 5, § 13 (giving the Attorney General supervisory authority over "sheriff[s] and over such other law enforcement officers as may be designated by law"); N.Y. Const. art. 13, § 13 (giving the governor the authority to remove an elected sheriff).

313. See Conn. Const. amend. art. XXX (repealing art. 4, § 25).

314. See, e.g., Christopher v. Sussex County, 77 A.3d 951, 958 (Del. 2013); Prince George's County, 731 A.2d at 894.

315. See, e.g., Jonathan W. Acton, II, Note, The Maryland Sheriff v. Modern and Efficient Administration of Justice, 2 U. Balt. L. Rev. 282, 286 (1973) ("The majority view was that, because the sheriff was a constitutional officer, the legislature might impose additional duties upon him, but could not restrict or reduce the powers granted him by the constitution (i.e., those powers recognized by custom and common law at the time the constitution was adopted).").

316. See William L. Murfree, A Treatise on the Law of Sheriffs and Other Ministerial Officers, at v, 22-23 (2d ed. 1880) (noting that it is beyond the power of legislatures "to circumscribe [the sheriff's] common-law functions or to transfer them to other officers"). 
held that "the office of sheriff is a 'constitutional' office, whose basic, fundamental duties may not be legislatively modified." ${ }^{17}$ Similarly, in Florida, an Attorney General opinion argued that sheriffs, as constitutional officers, were exempt from competitive bidding regulations. ${ }^{318}$ All of this stands in sharp contrast to the traditional account of local government officials and the fundamental principles of "Dillon's Rule"-that such officials possess only those powers that have been specifically delegated to them by the state. ${ }^{319}$

The legal structure of sheriffs then is far more resistant to disbandand-reform efforts than that of municipal police departments. County governments, including the boards of supervisors that oversee them, can amend the local ordinances that county sheriffs enforce and exercise some influence through the appropriations process. But unlike city police chiefs, sheriffs neither work for nor answer to local government. In fact, constitutional provisions in states like Florida specifically prohibit counties from abolishing the office of the sheriff or transferring their duties to another officer or office. ${ }^{320}$ With respect to counties, an old adage goes: " $[\mathrm{T}]$ he legislature may create municipalities, but only God can create a county." " ${ }^{21}$ A similar comparison might also be drawn between the police and sheriffs.

2. History. - The insulation of the sheriff from structural reform is connected to its unique historical origins. If police and sheriffs serve similar roles today, they reached this point from very different directions.

Municipal police departments were imagined right from the beginning as law enforcement agencies. ${ }^{322}$ To be sure, their specific duties and responsibilities have been subject to endless debates and reforms ${ }^{323}$ But it was always assumed that their role would primarily be in the context of public safety and order. Sheriffs, in contrast, did not begin as officials primarily concerned with law enforcement duties. ${ }^{324}$ Their origins can be

317. 251 Cal. Rptr. 444, 447 (Ct. App. 1988) (noting that "the weight of authority in the United States holds that the office of sheriff is a 'constitutional' office, whose basic, fundamental duties may not be legislatively modified" before declining to follow this practice in California (quoting $1 \mathrm{McQuillin}$, supra note 204, § 1.27)).

318. Fla. Att'y Gen. Op. 078-122, 1978 Fla. AG LEXIS 49, at*2 (Oct. 20, 1978).

319. See 2 McQuillin, supra note 204, § 4:11.

320. Fla. Const. art. VIII, § 1(d).

321. Rusk, supra note 296, at 93.

322. See Johnson, supra note 242, at 16-22 (describing early police forces in New York City and Philadelphia).

323. See, e.g., Fogelson, supra note 256 , at 84-89 (detailing early police reform efforts).

324. See Tomberlin, supra note 286, at 117-19 (outlining the duties of sheriffs in preAmerican history). As James Tomberlin details, "Variation in the sheriff's duties and importance tracked the importance of counties generally in the different colonies: in the northern colonies, counties were limited to judicial matters; in the Mid-Atlantic colonies, counties shared power with towns; and in the southern colonies, counties represented 'the very foundation of local government.'” Id. at 119 (quoting J. Edwin Benton, Counties as Service Delivery Agents: Changing Expectations and Roles 7 (2002)). 
traced to ninth-century England, when they were executive agents of the King. ${ }^{325}$ In the colonies, sheriffs served as local administrators of colonial governments and later the states, especially in the South. ${ }^{326}$ The early responsibilities of sheriffs were largely in the areas of tax collection, adjudication, and executive administration. ${ }^{327}$ Their law enforcement activities were largely tied to their administration of the courts and the judicial process. ${ }^{328}$ Many were directly appointed by the governor of their states. ${ }^{329}$ And although empowered to deputize local residents to quell riots and insurrections, they were not initially responsible for general law enforcement responsibilities. ${ }^{330}$

Two developments shifted sheriffs' mandate toward law enforcement. The first was the model provided by the new urban police. ${ }^{331}$ The law enforcement role of sheriffs varied by region. In the South, the precursors were fugitive slave patrols. ${ }^{332}$ Like these patrols, sheriffs were compensated on a fee structure. ${ }^{333}$ After the civil war, sheriffs established systems of prison labor to generate revenue. ${ }^{334}$ In the West, sheriffs assumed the role of frontier lawmen and were also largely compensated by fees. ${ }^{335}$ Second, the establishment of general-purpose county governments in the nineteenth century shifted many executive roles from sheriffs to elected county

325. See Falcone \& Wells, supra note 284, at 125 ("The modern-day American sheriff's office traces its historical antecedents to tenth century England and the 'shire-reeve', a local political figure, who was appointed to serve and protect the King's interests in the shire."); Tomberlin, supra note 286, at 117, 120 (explaining that the colonial sheriff was an agent of the King in the colonies); Kawucha, supra note 283, at 20, 31 (detailing a sheriff's earliest role as tax collector for the King).

326. See Falcone \& Wells, supra note 284, at 125; Tomberlin, supra note 286, at 11922; see also Murfree, supra note 316, at 2 ("Now, as a thousand years ago, the sheriff is the chief executive functionary of the county ....").

327. See Tomberlin, supra note 286, at 120; Kawucha, supra note 283, at 20. Many of these duties are still provided for in state constitutions today. See, e.g., Tex. Const., art. VIII, $\S 14$ (b) (" $[\mathrm{T}]$ he sheriff of the county ... shall be the assessor-collector of taxes, except that the commissioners court of such a county may submit to the qualified voters of the county at an election the question of electing an assessor-collector of taxes as a county officer separate from the office of sheriff.").

328. See Kawucha, supra note 283 , at $84-85$.

329. See id. at 80-81, 85, 141, 151.

330. Cities employed watchmen and would call the state militia for riots or continuing violence. See Johnson, supra note 242, at 14, 25.

331. See Kawucha, supra note 283, at 92-93.

332. See id. at 111. Even after slavery was abolished, there were many accounts of sheriffs and their deputies participating or complicit in the lynchings. See William Fitzhugh Brundage, Lynching in the New South: Georgia and Virginia, 1880-1930, at 112-13, 146, 233, 253 (1993). But see E.M. Beck, Judge Lynch Denied: Combating Mob Violence in the American South, 1877-1950, 21 S. Cultures 117, 118-19 (2015) (detailing the sheriffs' roles in preventing lynchings).

333. See Kawucha, supra note 283, at 111-15.

334. See id. at 114 (explaining convict leasing).

335. See id. at 115-16 (outlining various fee-for-service schemes common among western sheriffs). 
boards. ${ }^{336}$ But sheriffs retained the law enforcement functions that they had recently assumed, along with their historic judicial duties of serving warrants and maintaining jails. ${ }^{337}$ After all, sheriffs were constitutional offices that could not be easily eliminated without a constitutional amendment.

These independent origins explain why sheriffs continue to operate at a remove from county governments and are more likely than police to exercise broad administrative responsibilities, such as the operation of jails, service and execution of judicial orders, and the transportation of prisoners. Moreover, the historic reliance of sheriffs on fees for service, ${ }^{338}$ and their historic role as tax assessors and collectors, ${ }^{339}$ continues to inform their law enforcement responsibilities. The fee mentality remained even when the sheriffs' role coalesced around law enforcement responsibilities. Sheriffs earned fees for arrests and sometimes executions. ${ }^{340}$ In the South, owners of enslaved persons paid the costs of fugitive slaves' detention in county jails along with separate "sheriff's fees" for the return of these enslaved persons. ${ }^{341}$ In the West, states like Arizona allowed the sheriff to charge the families of inmates for the inmates' incarceration. ${ }^{342}$ Today, sheriffs are still responsible for the collection of many fees, ${ }^{343}$ and the funding structure of sheriffs' offices continues to be far more entrepreneurial than that of police departments, from municipal contracts for police services to the "leasing" of excess prison capacity. ${ }^{344}$

336. See infra note 346 and accompanying text; see also, e.g., Boyd, supra note 291, at 152-72 (describing how the discretion of the sheriff, as a tax collector, was curtailed over time by the North Carolina legislature, in part due to administrative inefficiencies and abuses by the sheriffs); Kawucha supra note 283, at 164, 188 (noting that "[o]nly a few shrieval offices are still connected to tax collection").

337. See Soper v. Montgomery County, 449 A.2d 1158, 1161 (Md. 1982); Scott v. State, 231 A.2d 728, 732 (Md. Ct. Spec. App. 1967); Tomberlin, supra note 286, at 122.

338. Boyd, supra note 291, at 171 ("[R]evenues came from... (1) fees for the performance of orders of the court, such as making arrests, serving processes, [and] executing attachments [; . . . (2) commissions collecting the taxes; . . and (6) various other fees and commissions ....").

339. Boyd, supra note 291, at 155; Tomberlin, supra note 286, at 120; Kawucha, supra note 283 , at 99 .

340. See, e.g., Raymond Moley, The Sheriff and the Constable, 146 Annals Am. Acad. Pol. \& Soc. Sci. 28, 29-32 (1929).

341. Oscar Reiss, Blacks in Colonial America 189 (1997).

342. See Jane Eppinga, Arizona Sheriffs: Badges and Bad Men 77 (2006).

343. See, e.g., Kawucha, supra note 283, at 158, 160.

344. See, e.g., Peter J. Nelligan \& William Bourns, Municipal Contracting with County Sheriffs for Police Services in California: Comparison of Cost and Effectiveness, 14 Police Q. 70, 71 (2011); Jessica Pace, La Plata County Sheriff to Rent Jail Beds to Boost Revenue, Durango Herald (Jan. 8, 2017), https://durangoherald.com/articles/126626-la-platacounty-sheriff-to-rent-jail-beds-to-boost-revenue (on file with the Columbia Law Review) ("The La Plata County Sheriff's Office plans to close its budget gap this year by expanding its jail bed rental program."); supra note 306 and accompanying text. 
The status of sheriffs as state officers explains why reforms of sheriffs' offices were almost always initiated at the state rather than local level ${ }^{345}$ In some cases, these state reforms were the result of reorganizations of county governance. ${ }^{346}$ In others, they resulted from local controversies over corruption and abuse. ${ }^{347}$ In a few cases, reforms were tied to state assertions of power over municipal jurisdictions. ${ }^{348}$ This was how the City of Baltimore got both a municipal police department and a city sheriff's office. ${ }^{349}$ In addition, states often specified the role of sheriffs on a countyby-county basis, with different powers and duties assigned to different county sheriffs. ${ }^{350}$ This practice is now limited by prohibitions against special legislation. ${ }^{351}$ But state legislatures have sometimes succeeded in circumventing those, and special legislation enacted prior to those constitutional prohibitions remained..$^{352}$

This is not to say that local communities can never succeed in eliminating a sheriff's office. Complaints of corruption induced Connecticut to abolish the office of high sheriffs and transfer their employees to a state agency. ${ }^{353}$ Miami-Dade County managed to abolish its sheriff in $1957 .{ }^{354}$

345. Ind. Code $\$ 36-8-10-3$ (2020) (creating and governing sheriff's merit board under state law).

346. See, e.g., John Archibald Fairlie, Local Government in Counties, Towns and Villages 106-12 (1906) (describing, at the turn of the twentieth century, how many historic powers of the sheriff were transferred to newly created county offices); see also Edmund Thornton Miller, A Financial History of Texas 204-05 (1916) (describing the evolving role of the sheriff as the county tax collector).

347. See, e.g., Christopher Hoffman, Connecticut Voters Decide to Abolish Controversial Sheriff System, Middletown Press (Nov. 8, 2000), https://www.middle townpress.com/news/article/Connecticut-voters-decide-to-abolish-11939612.php [https:// perma.cc/8LSW-EULK] (last updated Aug. 18, 2017) (outlining reasons motivating the abolition of the office of sheriff in Connecticut).

348. See, e.g., Baltimore v. State, 15 Md. 376, 400-01 (1860) (upholding a state law that places both the Baltimore Police Department and its sheriff under a state-controlled Board of Police); Howard O. Sprogle, The Philadelphia Police, Past and Present 86-87 (1887) (describing an 1845 Pennsylvania law that granted the sheriff the power to call upon the police forces of Philadelphia and surrounding municipalities for the purposes of suppressing riots in those municipalities).

349. See Md. Const. art. IV, $\S 44$ (establishing the office of Baltimore City Sheriff); Md. Code Ann., Cts. \& Jud. Proc. \$2-316 (West 2020) (fixing the salary of the Sheriff of Baltimore City); Baltimore v. State, 15 Md. at 394, 401; Sheriff of Baltimore City and County, Balt. Sun (Mar. 13, 1844) (on file with the Columbia Law Review) (reporting on an amendment to the Maryland Constitution, which provided for the election of both a city and a county sheriff).

350. See Ala. Code $\$ 45-2-237$ (2020) (requiring municipalities in Baldwin County to inform the sheriff of decision to stop enforcing certain laws); Kline v. Fuller, 467 A.2d 786, 789 (Md. Ct. Spec. App. 1983) ("Although the sheriff is a State official, his duties and authority are not uniform throughout the State.... [T] he General Assembly has treated the sheriff somewhat differently from county to county.").

351. See supra notes 227-229 and accompanying text.

352. See supra notes 229-231 and accompanying text.

353. See Tomberlin, supra note 286 , at 145-46; supra note 347.

354. See Dade County v. Kelly, 99 So. 2d 856, 856-59 (Fla. 1957). 
Yet unique legal conditions account for this. The state constitution was amended in 1956, granting Dade County authority to adopt a home-rule charter that abolished constitutional offices like that of the sheriff. ${ }^{355}$ Dade County passed such a home-rule charter that same year, creating the metropolitan government of Miami-Dade and delegating the power to abolish constitutional offices to the county board. ${ }^{356}$ When the sheriff challenged the abolition of his office through ordinance, the Florida Supreme Court found that the county possessed the power to do so. ${ }^{357}$ But while that decision was based on the county's home-rule powers, the constitutional foundations of those powers meant they were also subject to subsequent amendment. And this is what happened in 2018 when a constitutional amendment was approved by voters, ${ }^{358}$ requiring an independently elected sheriff in all Florida counties and forbidding abolition by county charter. ${ }^{359}$ Given that the sheriff's responsibility had been absorbed into the Miami-Dade Police Department, the county is now in the process of figuring out how to transfer power and duties back by 2024, when the first election for the newly restored office will be held. ${ }^{360}$

Given this history, any effort to disband sheriffs' offices will be embroiled in state-local battles. This is especially true where blue metropolitan counties clash with red-state leaders. But to a greater extent than for urban police departments, disbanding and replacing sheriffs will likely require state constitutional authorization and state political support.

\section{Intergovernmental Interactions}

The structural barriers to disbanding police departments and sheriffs' offices extend beyond those that emerge from the legal structures and institutional histories examined above. Additional structural challenges

355. See id. at 857 .

356. See id.

357. See id. at 859 (holding that the County may enact "an ordinance . . . abolishing the office of Sheriff and transferring all of the functions thereof").

358. See Douglas Hanks \& Charles Rabin, After a Storied History of Bad Sheriffs, MiamiDade Voters Will Elect Them Again, Mia. Herald (Nov. 8, 2018), https://www.miamiherald. $\mathrm{com} /$ news/politics-government/election/article221285885.html (on file with the Columbia Law Review).

359. The Florida Constitution states:

There shall be elected by the electors of each county, for terms of four years, a sheriff.... Notwithstanding subsection 6(e) of this article, a county charter may not abolish the office of a sheriff... transfer the duties of those officers to another officer or office; change the length of the four-year term of office; or establish any manner of selection other than by election by the electors of the county.

Fla. Const. art. VIII, $\S 1(\mathrm{~d})$.

360. See, e.g., Douglas Hanks, Miami-Dade Must Hold Partisan Elections for Sheriff, Court Clerk, Supreme Court Says, Mia. Herald (Aug. 12, 2019), https://www. miamiherald.com/news/local/community/miami-dade/article233791657.html (on file with the Columbia Law Review). 
appear when we consider the institutional relationship between cities and counties, and police departments and sheriffs' offices. In other words, the prospects for radical reforms turn not only on the structural entrenchment of local law enforcement agencies individually, but on their possible substitution for one another.

Because county and city jurisdictions often overlap, with counties usually encompassing cities within them, sheriffs and municipal police departments ordinarily exercise concurrent jurisdiction over the cities. ${ }^{361}$ Yet, although counties often envelop cities, counties are not higher in the governmental hierarchy. Finally, where they overlap with cities, county electorates include additional voters with different interests, demographics, and politics.

All of this implies that city-county conflicts might impede local efforts to radically reform policing. Moreover, given the functional divide of cities and counties with respect to social services programs-like mental health and economic development-any shift of resources from police to these functions will likely require intergovernmental cooperation between the two. The next section examines both how city-county and police-sheriff interactions could complicate radical restructuring of policing. Moreover, we suggest a third complication with respect to law enforcement: the possibility that radical reforms at the local level will be subverted by efforts to expand the jurisdictional scope of the state police.

1. The Outsourcing of Municipal Services. - For many cities, radical reforms of policing will require navigating municipal charters, state law, and sometimes state constitutional provisions. But for many others, the path toward radical reforms will also need to go through the sheriff and the county governments.

One reason is that many cities do not have municipal police departments at all. ${ }^{362}$ To be sure, policing is generally considered to be an essential function of municipal governments. But instead of providing that service themselves, smaller and distressed cities tend to outsource that responsibility to the county sheriff. ${ }^{363}$ In some cities, like Compton in

361. See supra note 284 and accompanying text.

362. See, e.g., Leroy D. Baca, L.A. Cnty. Sheriff's Dep't, Contract Law Enforcement Services 8 (2009), https://www.sheriffs.org/sites/default/files/uploads/CLESDocument. pdf [https://perma.cc/WQ8S-WNWT] (listing forty cities that the Los Angeles Sheriff's Department provides police services for); Kawucha, supra note 283, at 142, 144, 146-48, 152, 162 (providing examples of where sheriffs contract police services in a number of states); Contract Law Enforcement, Wright Cnty. Minn., https://www.co.wright.mn.us/ 222/Contract-Law-Enforcement [https://perma.cc/29LW-DZMU] (last visited Jan. 14, 2021) ("Presently the Wright County Sheriff's Office provides contract law enforcement services to 13 of the 16 cities in Wright County. Only the Wright County cities of Annandale, Buffalo and Howard Lake have their own police departments.").

363. See Nelligan \& Bourns, supra note 344 , at 71 . In states without counties, like Connecticut, small municipalities often contract with the state police. See Noah Kazis, Special Districts, Sovereignty, and the Structure of Local Police Services, 48 Urb. Law. 417, 430 (2016). On state police, see infra section II.C.3. 
California ${ }^{364}$ and Camden in New Jersey ${ }^{365}$ budget shortfalls convinced city officials to disband their police departments and contract with the county sheriff for law enforcement services. Other cities never established municipal police departments. Rather, following a plan first developed by Lakewood, California, cities contracted with county sheriffs for police protection right from the start. ${ }^{366}$ These tended to be prosperous communities planning to provide few municipal services on their own, which incorporated as cities largely to resist annexation into larger, more ethnically diverse cities. ${ }^{367}$ Then there are the townships and unincorporated communities that do not have the power to establish municipal police departments at all, and fall within the jurisdiction of the county generally. ${ }^{368}$ And while unincorporated communities tend to be rural and sparsely populated, that category also includes some densely populated urban areas like East Los Angeles (with more than 100,000 residents) and Paradise, Nevada, where the Las Vegas strip is located. ${ }^{369}$

For all these communities, radical reforms of local policing require restructuring sheriffs' offices over which they have no direct control. Nor are county sheriffs politically accountable to the city governments that contract for their services. To be sure, the contracts themselves might provide larger cities with some measure of influence and leverage. This may be why Camden's contract is largely seen as successful among local residents even though direct local control over policing was lost. ${ }^{370}$ But for smaller cities lacking the fiscal capacity to establish their own police departments, the sheriff holds a monopoly. These cities have no choice but to buy from the sheriff, but the sheriff has no obligation to sell, leaving

364. See Emily E. Straus, Death of a Suburban Dream: Race and Schools in Compton, California 225 (2014); see also Nicholas Corsaro \& Jeremy M. Wilson, The Effects of Police Contracting on Crime: An Examination of Compton, California, 14 J. Experimental Criminology 59, 64-67 (2018) (discussing problems plaguing the Compton police department).

365. See Goldstein \& Armstrong, supra note 177 (“[I]n 2013, the mayor and city council dissolved the local PD and signed an agreement for the county to provide shared services."); Sarah Holder, The City that Remade Its Police Department, Bloomberg Businessweek (June 4, 2020), https://www.bloomberg.com/news/articles/2020-06-04/how-camden-new-jerseyreformed-its-police-department (on file with the Columbia Law Review) (reporting that Camden's decision to disband its policing was motivated by "dire finances").

366. See Miller, Cities by Contract, supra note 306, at 22-26 (detailing the origin of Lakewood's contractual relationship with the county sheriff's office).

367. See id. at 17-26 (describing the conflict between municipalities and neighboring unincorporated territory over annexation).

368. See, e.g., Michelle Wilde Anderson, Cities Inside Out: Race, Poverty, and Exclusion at the Urban Fringe, 55 UCLA L. Rev. 1095, 1108 (2008).

369. See Robert E. Lang \& Dawn Dhavale, Reluctant Cities?: Exploring Big Unincorporated Census Designated Places, Metropolitan Institute at Virginia Tech Census Note 03:01, at 1-3 (July 2003).

370. See Goldstein \& Armstrong, supra note 177 (describing how the restructured Camden police force is viewed by locals as "fairer, less menacing and more effective than in the past"). 
cities without leverage ${ }^{371}$ An example is the case of the city of Guadaloupe, Arizona, a predominantly Latinx community with approximately 5,500 residents. ${ }^{372}$ When Sheriff Joe Arpaio dramatically escalated his immigration enforcement activities in the city, including an extended raid in 2008, the residents and leaders of the city protested. ${ }^{373}$ In response, the sheriff unilaterally cancelled his contract with the city, stating, "If you don't like the way I operate, you go get your own police department." 374 With few alternatives, the city eventually capitulated and reinstituted its contract with Arpaio on the sheriff's terms. ${ }^{375}$

Cities interested in shifting resources and functions from law enforcement to social service agencies or community economic development programs may find that they need the cooperation of county government. Currently, most of these social services are handled at the level of county government and not by the cities themselves. ${ }^{376}$ Thus, reallocating traditional local law enforcement responsibilities to other social service providers may require coordination between cities and counties. This suburbanization of social services broadens the tax base supporting them, with redistributive effects, but also reduces the political control of urban populations reliant on those services. Perhaps demographic and economic shifts now better enable some cities to provide these services. But even then, legal reforms might be required to redirect state and federal funds for those services to these city departments and to coordinate the responsibility of municipal social services with that of the county. A city might instead decide to contract for new, enriched services with the county. But that would require the willingness of the county, while the city would lose direct political control of an important component of its new public safety program.

2. The Overlapping Jurisdiction of Police and Sheriffs. - Another intergovernmental challenge facing radical reform efforts is the possibility that sheriffs' offices would be used to thwart efforts to disband and reform municipal police departments. In other words, the concurrent jurisdiction of the sheriff is a constraint even in the cities that have not contracted for

371. Nelligan \& Bourns, supra note 344 , at 89.

372. See Mary Romero, Keeping Citizenship Rights White: Arizona's Racial Profiling Practices in Immigration Law Enforcement, 1 L.J. for Soc. Just. 97, 109-10 (2011).

373. See id. at 110-11.

374. See Stephen Lemons, Guadalupe Made It Clear that Joe Arpaio's Attacking Anyone with Brown Skin, Phx. New Times (May 29, 2008), https://www.phoenixnewtimes.com/ news/guadalupe-made-it-clear-that-joe-arpaios-attacking-anyone-with-brown-skin-6431117 (on file with the Columbia Law Review).

375. See Tomberlin, supra note 286, at 139.

376. See, e.g., Comm. for the Study of the Future of Pub. Health, Inst. of Med., The Future of Public Health 186 (1988) (showing that a majority of local health agencies operate at the county level or above, with only about twenty-three percent under the control of a city or town). 
their services. ${ }^{377}$ Of course, there are exceptions. ${ }^{378}$ Some states, especially those in the Northeast, have either abolished the office of the sheriff or limited its responsibilities. ${ }^{379}$ Some metropolitan governments, like MiamiDade County, consolidated the sheriff's office with the police department ${ }^{380}$ - though, as noted earlier, this particular arrangement will likely be unwound. Moreover, in areas where sheriffs and police departments share concurrent jurisdiction over the city, the general practice is for both to organize their activities into respective turfs. ${ }^{381}$ Sheriffs' offices tend to focus their attention on areas of the county not served by municipal police departments. ${ }^{382}$

But that comity could disappear if a city's plans to radically reform law enforcement provoke an entrenched sheriff or suburban voters. If a city were to disband its police department, a county sheriff might take its place-resulting in conventional policing even less accountable to city residents. A city's plans to deprioritize certain crimes, or ban certain police practices, would be frustrated. Indeed, some courts have suggested that it is a duty for the sheriff to intervene if they believed that a municipal police force is "neglecting its duty" by "ignoring or permitting offenses." 383

377. See, e.g., People v. Scott, 66 Cal. Rptr. 257, 265 (Ct. App. 1968); State ex rel. Danforth v. Orton, 465 S.W.2d 618, 626 (Mo. 1971); In re Sulzmann, 183 N.E. 531, 532 (Ohio 1932); State ex rel. Windham v. LaFever, 486 S.W.2d 740, 742 (Tenn. 1972); Commonwealth ex rel. Davis v. Malbon, 78 S.E.2d 683, 686 (Va. 1953) (holding that the jurisdiction of the sheriff extends throughout the county, inclusive of any municipalities therein); see also Falcone \& Wells, supra note 284, at 129.

378. See Kawucha, supra note 283, at 150 ("Like some cities in Virginia, St. Louis is an independent city, meaning it is a separate entity from the surrounding county. As such, the St. Louis County Sheriff has no jurisdiction within the city boundaries . . . ; the St. Louis City Sheriff has that responsibility.").

379. See, e.g., Conn. Const. art. XXX, § 1 (repealing $§ 25$ of article IV and abolishing the office of sheriff).

380. See Mia.-Dade Cnty., Fla., Charter, $§ 9.01(C)$ (2018); Memorandum from Charles Anderson, Comm'n Auditor, Bd. of Cnty. Comm'rs, to Hon. Joe A. Martinez, Chairman, Bd. of Cnty. Comm'rs 2-3 (June 29, 2011), https://www.miamidade.gov/auditor//library/ consolidating-certain-functions-MDPD-MDCR.pdf [https://perma.cc/R8QG-SSND].

381. See, e.g., State v. Knight, 904 P.2d 1159, 1165 (Wash. Ct. App. 1995) ("As the Washington Attorney General has observed: 'Nowhere has the [Washington] Legislature indicated that the sheriff's powers and duties are limited to the unincorporated areas of the county." (quoting Interlocal Cooperation Act, Op. Att'y Gen. AGO 1990 No. 4, at 2 (Wash. May 24, 1990))).

382. See, e.g., id.

383. See State ex rel. Danforth v. Orton, 465 S.W.2d 618, 626-27 (Mo. 1971); accord State ex rel. Thompson v. Reichman, 188 S.W. 225, 228 (Tenn. 1916) (holding that where a sheriff "knows that the city officials are deliberately ignoring or permitting a certain class of offenses," the sheriff must "prevent and suppress such offenses" as if "there was no municipality ... police force"); Commonwealth ex rel. Davis v. Malbon, 78 S.E.2d 683, 686 (Va. 1953) (stating that where a sheriff "knows that any ... officer is deliberately ignoring or permitting violations of [the] law," he has a "duty to take proper steps to prevent and suppress such violations"). 
To be sure, accounts from cities like Camden suggest that county takeovers might sometimes be effective reforms. ${ }^{384}$ By disbanding its police department and contracting with the county sheriff, Camden was able to offer its residents a new start in their relationship with law enforcement. ${ }^{385}$ But there are counterexamples as well, especially when the county electorate is politically and socioeconomically distinct from the city's. Consider Sheriff Arpaio of Maricopa County. For several years, he clashed with local leaders in Phoenix and Mesa over immigration enforcement in their cities. ${ }^{386}$ But city leaders were powerless, because Arizona law grants Arpaio's sheriff's office concurrent jurisdiction in their cities. ${ }^{387}$ And Sheriff Arpaio was willing to flout conventional norms by actively patrolling in these cities on the view that their police departments were abdicating their responsibilities to enforce immigration law. ${ }^{388}$ Ultimately, Sheriff Arpaio was voted out of office and convicted of criminal contempt for violating a court order to desist from civil rights violations. ${ }^{389}$ Until then, however, there was little that the residents of Phoenix or Mesa were able to do to influence, much less control, the activities of their sheriff in their jurisdiction. This was especially true when the sheriff retained the support of the state legislature.

The example of Sheriff Arpaio also illustrates the limits of political influence that a city can exercise through contracting. Camden suggests that even if county sheriffs are less politically accountable to city residents than municipal police departments, city governments can still exercise some degree of influence over their activities through their contracts with the sheriff's office. ${ }^{390}$ But while this might be more effective with respect to larger cities that provide substantial funds to the county sheriff's office, smaller cities usually have little market leverage over the law enforcement activities of the sheriffs for which they contract. This is especially true if those cities do not have the fiscal capacity or political will to set up a police department of their own. Moreover, as Sheriff Arpaio astutely noted when

384. See Goldstein \& Armstrong, supra note 177; Holder, supra note 365.

385. See supra note 384 and accompanying text.

386. See Tomberlin, supra note 286, at 139-41; Nicholas D. Rizzi, Joe Arpaio and the Phenomenon of the 'Toughest Sheriff in America', 20, 82-84, 86 (Dec. 2016) (M.A. Thesis, Sam Houston State University) (on file with the Columbia Law Review).

387. See Ariz. Rev. Stat. § 11-441 (2020); see also Terry Greene Sterling, Phoenix's Crackdown on Illegal Immigration, Newsweek (Apr. 14, 2008), https://www.newsweek. com/phoenixs-crackdown-illegal-immigration-86429 (on file with the Columbia Law Review) ("The sheriff, who has concurrent jurisdiction to enforce laws in Phoenix and other towns in Maricopa County, says ... he's simply enforcing the law.").

388. See, e.g., Paul Giblin, Arizona Sheriff Conducts Immigration Raid at City Hall, Angering Officials, N.Y. Times (Oct. 17, 2008), https://www.nytimes.com/2008/10/18/ us/18immig.html (on file with the Columbia Law Review).

389. See Richard Pérez-Peña, Former Arizona Sheriff Joe Arpaio Is Convicted of Criminal Contempt, N.Y. Times (July 31, 2017), https://www.nytimes.com/2017/07/31/ us/sheriff-joe-arpaio-convicted-arizona.html (on file with the Columbia Law Review).

390. See supra notes 363-368 and accompanying text. 
a number of cities threatened to withdraw from their contract with his department, such withdrawal does not affect the baseline authority of the sheriff to engage in law enforcement activities within those cities. ${ }^{391}$

Even among sheriffs, Arpaio was an outlier. But his example illustrates how sheriffs might be deployed by the state to frustrate police disbanding. Practical constraints that currently keep sheriffs and police on different jurisdictional turfs are likely to hold when political lines sharpen. Comity between sheriffs and police departments might break down if cities are perceived as going too far, and especially if sheriffs have the active support of the state. And the funding constraints that currently incentivize sheriffs to limit their responsibility to areas outside of cities can easily be removed. States can expand funding directly. They can direct local reimbursements, as they have done in the past with state-controlled police forces. ${ }^{392}$ They can levy additional local taxes. In sum, the concurrent jurisdiction of sheriffs is a powerful weapon that the state, the sheriff, or suburban voters can deploy to frustrate radical reform of policing.

3. The Possible Expansion of the State Police. - The last intergovernmental interaction that cities must consider is that between municipal police departments and the state police. Rather than relying on sheriffs, states bent on limiting local control over law enforcement might assume control by expanding the authority and responsibilities of existing state police.

Since the early twentieth century, states have created a large number of state police departments directly under state control. The names for these departments vary-in some states they are referred to simply as the state police or state troopers, and in others they are known as state patrols or highway patrols. ${ }^{393}$ Nonetheless, their responsibilities are usually quite similar. They patrol freeways, highways, and other interlocal routes that cross multiple local jurisdictions. ${ }^{394}$ They coordinate multijurisdictional investigations involving multiple local law enforcement agencies. ${ }^{395}$ They also oversee security for state facilities, like the legislative building or the governor's office. ${ }^{396}$

391. See Tomberlin, supra note 286, at 139-140 ("Sheriff Arpaio claimed that even if Guadalupe stopped contracting with him, he would still have the authority to perform his sweeps within Guadalupe.”).

392. See, e.g., State ex rel. Reynolds v. Jost, 175 S.W. 591, 593-94 (Mo. 1915).

393. See, e.g., Beverly A. Smith \& David N. Falcone, Highway or State Patrols and State Police, in 1 Encyclopedia of Police Science 1197, 1197-98 (Jack R. Greene ed., 3d ed. 2007).

394. See H. Kenneth Bechtel, State Police in the United States: A Socio-Historical Analysis 42-44 (1995).

395. See Weldon Cooper, The State Police Movement in the South, 1 J. Pol. 414, 42426 (1939); Bruce Smith, Factors Influencing the Future Development of State Police, 23 J. Crim. L. \& Criminology 713, 715-16 (1932).

396. See, e.g., Ky. Rev. Stat. Ann. $§ 16.065$ (West 2020) (assigning to the Kentucky State Police responsibility over "[s] ecurity of state facilities located in Frankfort"); N.C. Gen. Stat. $\S 143 B-911$ (2020) (creating the North Carolina State Capitol Police Division within the Department of Public Safety). 
As a result, modern state police departments tend to supplement, rather than supplant, the jurisdiction of local law enforcement agencies. But this does not mean states cannot expand their authority over policing. Indeed, the origins of the state police reveal a much more expansive set of enforcement responsibilities. The Texas Rangers, established in the early nineteenth century as the nation's first state police force, were originally charged with protecting settlers from Native Americans and later participated in armed conflicts with the Mexican military ${ }^{397}$ State police forces proliferated in the early twentieth century as a means of putting down labor strikes, especially in communities where local law enforcement agencies were sympathetic to the plight of workers. ${ }^{398}$ The use of state police further increased in the twentieth century with the rise of prohibition and state efforts to combat the illegal production and distribution of alcohol. This expansion of state policing mobilized some of the same nativist and racist sentiments that propelled early twentieth century reforms of police departments: Labor unrest and alcohol abuse were widely perceived at the time to be problems associated with immigrant and minority communities. ${ }^{399}$ It was only later, with the expansion of automobile usage and cross-state travel, that the state police were reoriented toward highway patrol and traffic stops. ${ }^{400}$ And even there, the shadow of discriminatory enforcement remained, especially with respect to drug and immigration enforcement. ${ }^{401}$

This history suggests that disband-and-reform efforts at the local level may not only have to navigate the legal obstacles posed by state law and the concurrent jurisdiction of county sheriffs. They also have to contend with the possibility that radical restructuring may be undermined by an expansion of the state police force. The early use of the state police to further state interests in local jurisdictions provides one such model. In fact, in many states, the formal legal authority for the state police to act as a substitute for local police departments already exists. ${ }^{402}$ In Texas, for example, state law not only grants general law enforcement powers to the Department of Public Safety that oversees the Texas Rangers and the state

397. See Bechtel, supra note 394 , at 34 .

398. See, e.g., Gerda W. Ray, From Cossack to Trooper: Manliness, Police Reform, and the State, 28 J. Soc. Hist. 565, 566-67 (1995).

399. See id. at 569; see also Lisa McGirr, The War on Alcohol: Prohibition and the Rise of the American State 14-15, 90 (2016).

400. See Bechtel, supra note 394, at 40.

401. See, e.g., Samuel R. Gross \& Katherine Y. Barnes, Road Work: Racial Profiling and Drug Interdiction on the Highway, 101 Mich. L. Rev. 651, 660 (2002) (concluding that " $[\mathrm{t}]$ he Maryland State Police... engage[d] in racial profiling on I-95"); Anthony E. Mucchetti, Driving While Brown: A Proposal for Ending Racial Profiling in Emerging Latino Communities, 8 Harv. Latino L. Rev. 1, 14, 17, 32 (2005) ("Studies performed nationwide have consistently shown that Latinos are being stopped and searched by police officers at levels well beyond their proportion to the local population" (footnote omitted)).

402. See, e.g., N.C. Gen. Stat. § 20-188 (2020); Va. Code \$ 52-8 (2020); W. Va. Code Ann. § 15-2-12 (LexisNexis 2020). 
highway patrol, ${ }^{403}$ but it also requires sheriffs and police officers to comply with directives from the state department. ${ }^{404}$ All that would be required to thwart radical reforms at the local level would be for the state legislature to appropriate sufficient funding and a governor to appoint commissioners who are willing to see it through.

Here again, we see the complex web of interagency and intergovernmental relationships that actually makes up our country's "decentralized" system of law enforcement. Although we have no national police force, our system does not place control at the local level. Veto points are found at all levels of state governments, making it hard to eliminate a particular police agency, and harder still to eliminate the police function. Overlapping jurisdictions imply that many substitutes can usually be found for any disbanded agency. Although agencies at different levels of government often refrain from duplicating effort, that comity will not prevent a state takeover in a context of political conflict.

\section{LAW ENFORCEMENT EXCEPTIONALISM AND THE CHALLENGE OF DISBANDING}

Any effort to disband police agencies must contend with the legal entrenchment of police and sheriffs' offices described above. This Part analyzes the nature, causes, and consequences of this entrenchment. First, we observe that this entrenchment differentiates law enforcement from most other local government agencies. This law enforcement exceptionalism insulates police agencies from democratic pressures and thereby calls into question their political legitimacy. Next, we observe that this troubling state of affairs resulted from the strategic choices of past reformers: In an effort to consolidate their gains, past reformers created a set of institutional arrangements that strengthened police autonomy and blocked subsequent structural reforms. Third, we argue that those working to disband should learn from this history and avoid entrenching whatever replaces current police agencies. That is, disbanders should prioritize structural as well as substantive reforms, thereby leaving the path open to further democratic experimentation. ${ }^{405}$ Specifically, we urge activists and policymakers to work toward consolidating authority over law enforcement at one level of government, and ideally at the most local level.

403. See Tex. Gov't Code $\$ \S 411.002,411.022$ (2019).

404. See id. \$ 411.009.

405. See generally Rahman \& Simonson, supra note 85 (discussing the importance of structural reforms as "antidotes to the antidemocratic nature of many systems of law and governance," which may allow for "push back on the antidemocratic structures of law themselves" (emphasis added)). 


\section{A. The Structural Problem: Law Enforcement Exceptionalism}

In examining the challenge of police disbanding, we have shown how local law enforcement is constituted by a web of overlapping legal authorities. Such an organizational structure insulates law enforcement from the oversight and policy discretion that local governments exercise over their other departments. This law enforcement exceptionalism is an overlooked cause of law enforcement's "democratic vacuum." ${ }^{406}$ Specifically, law enforcement exceptionalism has two troubling consequences. First, it clouds the public's understanding of the legal identity of police agencies, and thereby frustrates the public's efforts to organize around reform. Second, law enforcement exceptionalism proliferates veto points, which police agencies leverage to avoid accountability. Together, these implications call into question the democratic legitimacy of police agencies.

We have already described in detail the institutional arrangements that give rise to law enforcement exceptionalism. ${ }^{407}$ To summarize, local police departments are structured by a mix of city ordinances, municipal charters, state law, and state constitutional provisions. ${ }^{408}$ Sheriffs are established by state constitutions and governed (if at all) by state law, while operating independently of the county boards that ostensibly govern their jurisdictions. ${ }^{409}$ To further complicate matters, the jurisdictions of municipal police departments and county sheriffs overlap, with cities sometimes contracting with counties for law enforcement protection and related public services ${ }^{410}$ Against this backdrop, state police departments supplement local law enforcement agencies but could be vastly expanded in reaction to radical reform efforts at the local level. ${ }^{411}$

These overlapping authorities make the legal identity of police agencies unlike that of a department of either local government or the state. City and county governments largely define the role and responsibilities of local departments of sanitation, public works, building, housing, planning, and parks, and these departments are frequently restructured or reorganized as a matter of local discretion. ${ }^{412}$ The same is usually the case

406. Friedman \& Ponomarenko, supra note 14, at 1835; see also supra notes 52-53 and accompanying text.

407. See supra Part II.

408. See supra section II.A.1.

409. See supra section II.B.1.

410. See supra section II.C.1-.2.

411. See supra section II.C.3.

412. See, e.g., James Beaty, Council to Discuss Reorganization of City's Departments, Including Possible Creation of a New Department of Public Works, McAlester News-Capital (Jan. 7, 2008), https://www.mcalesternews.com/news/council-to-discuss-reorganization-of-citys-departments-including-possible-creation-of-a-new-department/article_59203eed-c4ff-5ae4-88c0 -d52c90a07233.html (on file with the Columbia Law Review) (last updated Sept. 12, 2014); Alexandra Bjerg, Chico Latest California City to Restructure in Deficit Fight, CA Fwd (Mar. 8, 2013), https://cafwd.org/reporting/entry/chico-latest-california-city-to-restructure-in-deficitfight [https://perma.cc/33Q3-DC68]; Lisa Macneil, County Restructuring of Departments, 
for state departments, ${ }^{413}$ whose reorganization often leads to the dissolution of local offices of those departments. ${ }^{414}$ But since the waves of restructuring and reform that characterized the early history of local policing, police agencies have become insulated from structural reforms in ways unlike other municipal or state departments.

In this respect, a comparison might be drawn between the structural exceptionalism of police agencies and that of school districts. Like policing, public education is regulated by a web of state laws and local district policies regarding curriculum, teachers, and funding. ${ }^{415}$ But the structure of police agencies also differs in significant ways from that of school districts. Police are formally structured as municipal departments under the umbrella of, and funded by, city governments. In contrast, school districts are largely independent of local governments, funded directly through school taxes, and often serve jurisdictions that do not conform to local government boundaries. ${ }^{416}$ This independence is balanced by the fact that school districts are directly accountable to the electorate through the election of school boards ${ }^{417}$ which is similar to the direct election of sheriffs. But the state also exercises more power over school districts relative to sheriffs. Moreover, public schools are frequently disbanded and restructured, by such means as the dissolution of schools and change in personnel, ${ }^{418}$ the replacement of public schools with charter schools, ${ }^{419}$ and the remapping of school district boundaries. ${ }^{420}$

Hernando Sun (June 27, 2019), https:/ /www.hernandosun.com/article/county-restructuringdepartments (on file with the Columbia Law Review); Nikki Ross, South Daytona Looks to Restructure Public Works Department, Daytona Beach News-J. (Feb. 10, 2020), https:/ / www.news-journalonline.com/news/20200210/south-daytona-looks-to-restructurepublic-works-department [https://perma.cc/Q7Z4-Z2KH].

413. See, e.g., Michael R. Wickline, Bill Is Signed to Reorganize State Agencies, Ark. Democrat-Gazette (Apr. 12, 2019), https://www.arkansasonline.com/news/2019/apr/12/ bill-is-signed-to-reorganize-state-agen-1 (on file with the Columbia Law Review).

414. See, e.g., Geoff Pender, State Health Department Closing Two-Thirds of Regional Offices, Miss. Clarion Ledger (June 12, 2017), https:/ /www.clarionledger.com/story/news/ politics/politicalledger/2017/06/12/health-dept-provides-more-details-reorganization/39 0831001 [https://perma.cc/5ZU7-PLV8] (last updated June 13, 2017).

415. See Nadav Shoked, An American Oddity: The Law, History, and Toll of the School District, 111 Nw. U. L. Rev. 945, 954-55 (2017).

416. See id. at 958, 960-61, 1009-12. See generally Kazis, supra note 363 (noting and seeking to explain why policing has not been assigned to special districts, like schools).

417. See Shoked, supra note 415, at 960-61.

418. See, e.g., Craig Peck \& Ulrich C. Reitzug, School Turnaround Fever: The Paradoxes of a Historical Practice Promoted as a New Reform, 49 Urb. Educ. 8, 9-10 (2013).

419. See generally Danielle Holley-Walker, The Accountability Cycle: The Recovery School District Act and New Orleans' Charter Schools, 40 Conn. L. Rev. 125 (2007) (discussing the phenomenon of federal and state laws allowing charter schools to become an alternative to failing traditional public schools).

420. See, e.g., Erika K. Wilson, The New School Segregation, 102 Cornell L. Rev. 139, 174-75 (2016). 
Perhaps a better comparison is public authorities. Public authorities are local entities chartered by the state to focus on a specific governmental service, such as roads, mass transportation, and utilities. ${ }^{421}$ Many of their responsibilities were once the province of local governments, and many of them were created specifically by the state to take over existing municipal departments. ${ }^{422}$ Like the modern police department, public authorities were also the product of Progressive Era politics. ${ }^{423}$ As a result, even if structurally distinct, public authorities and police agencies share similar design principles. Public authorities were created as centralized and hierarchical institutions modeled after the modern corporation and structurally insulated from political accountability. ${ }^{424}$ They are considered a form of local government but are primarily subject to state law. ${ }^{425}$ Moreover, unlike cities and counties, which are general-purpose governments, public authorities and special districts focus on a specific mandate to the exclusion of competing public priorities. ${ }^{426}$

This comparison underscores the raw power of law enforcement agencies. As the head of numerous public authorities in the mid-twentieth century, Robert Moses reshaped New York City and New York State and became the most powerful figure in these arenas. ${ }^{427}$ But few people understood how he amassed or exercised this power, and fewer still could name the head of any public authority today. This anonymity is precisely the point: Public authorities operate outside of the normal channels of political accountability, and their power is obscured by design. To be sure, because they patrol in public and interact directly with citizens, police departments and sheriffs' offices are less insulated from the public gaze. But the structure and internal operations of police agencies are nearly as opaque.

421. See Kazis, supra note 363, at 424; Jerry Mitchell, Accountability and the Management of Public Authorities in the United States, 59 Int'l Rev. Admin. Scis. 477, 478 (1993).

422. See Annmarie Hauck Walsh, The Public's Business: The Politics and Practices of Government Corporations 3-5, 16-17 (1978) ("Some [public] authorities are empowered to condemn land or to exercise other police powers-over the use of waterways, for example, or over the behavior on toll highways or in housing projects.").

423. See Jameson W. Doig \& Jerry Mitchell, Expertise, Democracy, and the Public Authority Model: Groping Toward Accommodation, in Public Authorities and Public Policy: The Business of Government 17, 19-20 (Jerry Mitchell ed., 1992).

424. See id.; see also Walsh, supra note 422, at 5 .

425. See James Leigland, External Controls on Public Authorities and Other Special Purpose Governments, in Public Authorities and Public Policy: The Business of Government, supra note 423, at 31, 32-33.

426. See Robert G. Smith, Public Authorities, Special Districts and Local Government 180 (1964).

427. See Robert A. Caro, The Power Broker: Robert Moses and the Fall of New York 15 (1974) ("Moses was able to shape a city and to build an empire because [he] ... had focused on the possibilities of ... the public authority."). 
It should thus come as little surprise that the critiques of public authorities echo those of police agencies. Their insulated structure is said to breed corruption. ${ }^{428}$ Their single-purpose mission incentivizes them to privilege their organization's interests over the public interest. ${ }^{429}$ Not least, they can be instruments of racial subordination. ${ }^{430}$ But the consequences of law enforcement exceptionalism are perhaps worse than those of public authorities. Although public authorities have razed neighborhoods and harmed lives, ${ }^{431}$ they have not generally wielded armed force. In short, police departments and sheriffs' offices operate like Robert Moses, but with guns.

Moreover, law enforcement's liminal status as neither wholly local nor wholly state leaves it with no single master. This fragmentation of authority has two interrelated consequences for those who wish to check police power through democratic processes.

First, it shields police agencies from popular oversight. Although perceived by the public as departments of local government, their authority is derived from the police power of the state. ${ }^{432}$ City officials select the leadership of police departments, but state law controls how police officers are hired, disciplined, and terminated. ${ }^{433}$ Sheriffs are elected by local residents and operate in county jurisdictions. ${ }^{434}$ But they operate independently of county governments and, while subject to state

428. See Jerry Mitchell, Policy Functions and Issues for Public Authorities, in Public Authorities and Public Policy: The Business of Government, supra note 423, at 1, 8-9; Walsh, supra note 422 , at $38-39$.

429. See Doig \& Mitchell, supra note 423, at 23 ("Sometimes the executive staff[s] [of public authorities are] ... accused of ignoring community needs in the quest for budget surpluses and capital expansion .....”); Walsh, supra note 422, at 334-37. See generally Diana B. Henriques, The Machinery of Greed: Public Authority Abuse and What to Do About It 17 (1986) ("The mythology about the businesslike, uncorrupted public authority . .. ha[s] masked how vulnerable ... [they] really are to corruption ....").

430. See Caro, supra note 427, at 20 (" [T] he total number of people evicted from their homes for all Robert Moses public works ... is almost certainly close to half a million .... More significant even than the number of the dispossessed were their characteristics: a disproportionate share of them were black, Puerto Rican-and poor.").

431. See, e.g., id. at 850-62 ("[W] here once apartment buildings or private homes had stood were now hills of rubble, decorated with ripped-open bags of rotting garbage ....").

432. See, e.g., State ex rel. Reynolds v. Jost, 175 S.W. 591, 595-96 (Mo. 1915).

433. See supra section II.A.1. As we note, states' powers to regulate police by singling out specific cities through "special legislation" or by imposing a particular structural organization of municipal departments may be limited. See supra notes 227-239 and accompanying text. This means that the power of states to disband a specific police department may be more limited than their power to regulate policing or police personnel more generally.

434. See supra section II.B.1. 
control, are also partially insulated from the state as constitutional offices. ${ }^{435}$ Local governments must pay for both police and sheriffs, yet a significant portion of officers' compensation is set at the state level. ${ }^{436}$ And the existence, functions, and size of departments may be determined by state constitutions and city charters. ${ }^{437}$ This web of arrangements obscures who has authority to transform police agencies. Few municipal charters or state laws clearly authorize cities to disband and reform the police. ${ }^{438}$ The authority to disband or reform sheriffs' offices is even less clear. ${ }^{439}$ In most states, absent a state constitutional amendment, it is likely that neither county governments nor the state could radically restructure a sheriff's office. ${ }^{440}$ This diffusion of authority makes it difficult for the public to pin responsibility for pathological policing on any elected official.

Second, this diffusion of supervisory authority positions police agencies to play different levels of government off one another to thwart democratic reforms. One might argue that by straddling the state-local divide, police agencies are subject to additional scrutiny through "dual oversight by their local governments of general jurisdiction as well as by the state." ${ }^{441}$ Yet the varied and overlapping legal authorities that oversee police departments and sheriffs' offices can each more easily veto change than achieve it. To force change, activists must win in several different arenas. Perhaps more importantly, these veto points strengthen the political position of the law enforcement agencies themselves relative to those of elected state or local bodies. Local reforms can be impeded by existing or amended charter provisions, existing or new state laws, or even the prospect of preemptive legislation. State-led reforms are constrained by home-rule provisions that protect police departments as political subdivisions of the city or state constitutional provisions that enshrine the sheriff as a constitutional officer. ${ }^{442}$

435. See supra section II.B.1.

436. See Fung, supra note 15, at 89-91 (arguing that centralized funding is required to equalize the provision of services such as policing).

437. See supra section II.A.1.

438. See supra section II.A.1.

439. See supra section II.B.1.

440. See supra section II.B.1. The two major instances where a sheriff's office was disbanded both involved a constitutional amendment. See supra notes 353-355 (Connecticut and Miami).

441. Nestor M. Davidson, Localist Administrative Law, 126 Yale L.J. 564, 603 (2017).

442. See supra sections II.A.1, II.B.1. 
Police agencies are adept at exploiting these divides in their dealings with localities and the state. ${ }^{443}$ To repeal local residency requirements ${ }^{44}$ or restore an abolished sheriff's office, ${ }^{445}$ law enforcement unions and leadership turn to the state to pass a state law or amend the state constitution. ${ }^{446}$ And police can take advantage of earlier legislative victories at the state level to invalidate local reforms through litigation. ${ }^{447}$ To contest charter reforms affecting police departments, police can appeal directly to residents to thwart carefully designed ballot measures. ${ }^{448}$ And if state leadership seeks to disband or reform law enforcement, police can pressure local governments to obstruct these efforts.

This insulation from reform leaves police nearly impervious to popular discontent. The power thereby left unchecked is considerable. Recall that police have largely unregulated power to use deadly force. In addition, they exercise discretion over where to patrol, what and whom to investigate, whom to stop for furtive movement in a "high crime neighborhood" ${ }^{449}$ or arrest ${ }^{450}$ for commonplace traffic violations, ${ }^{451}$ and

443. See Lisa L. Miller, The Perils of Federalism: Race, Poverty, and the Politics of Crime Control 3-19 (2008) [hereinafter Miller, Perils] (arguing that the "presence of crime control as an active agenda item" across federal, state, and local government increases the likelihood that police agencies' policy preferences will be implemented at some level of government).

444. See, e.g., Joe Mulligan, Comment, Not in Your Backyard: Ohio's Prohibition on Residency Requirements for Police Officers, Firefighters, and Other Municipal Employees, 37 U. Dayton L. Rev. 351, 352-56 (2012) ("The Ohio Supreme Court ... ruled that the state statute trumped municipalities' efforts to impose residency requirements for city employees." (footnote omitted)).

445. See Editorial, With Florida Sheriffs Armed for a Fight, Champion Needed for Amendment 10 Repeal Effort, S. Fla. Sun Sentinel (Jan. 18, 2019), https://www.sunsentinel.com/opinion/editorials/fl-op-edit-amendment-10-repeal-20190104-story.html (on file with the Columbia Law Review).

446. See, e.g., David A. Harris, Failed Evidence: Why Law Enforcement Resists Science 123 (2012).

447. See, e.g., Julie Shaw, Philly's FOP Sues the City over Requirement for Public Hearing on Police Contracts, Phila. Inquirer (Oct. 14, 2020), https://www.inquirer.com/ news/philadelphia-police-contract-city-council-public-hearing-fop-lawsuit-20201014.html [https://perma.cc/PT3C-ZYHC] (describing the Philadelphia police union's lawsuit against the City, which alleged that a recently enacted ordinance-requiring a public hearing on proposed police-department contracts—violated a 1968 state law).

448. See, e.g., Joe Garofoli, While Some California Police Unions Promise Change, Others Seek to Undo Reforms, S.F. Chron. (June 18, 2020), https://www.sfchronicle.com/ politics/article/While-some-California-police-unions-promise-15348044.php (on file with the Columbia Law Review).

449. See Illinois v. Wardlow, 528 U.S. 119, 139 (2000) (Stevens, J., dissenting) (criticizing the majority and arguing that "in a high crime neighborhood unprovoked flight does not invariably lead to reasonable suspicion").

450. See Atwater v. City of Lago Vista, 532 U.S. 318, 323 (2001) (holding that the Fourth Amendment does not prohibit warrantless arrests for nonjailable violations).

451. See 2 Nat'l Highway Traffic Safety Admin., National Survey of Speeding and Unsafe Driving Attitudes and Behaviors: 2002, at 30 (2003), https:/ /www.nhtsa.gov/people/injury/ drowsy_driving1/speed_volII_finding/SpeedVolumeIIFindingsFinal.pdf (on file with the 
whether to leave serious crime unmolested. Moreover, American law enforcement rivals a large army in size. ${ }^{452}$ In any polity that claims to rest on popular consent, coercive force cannot be legitimately exercised on this scale without democratic accountability.

At present, there is a vigorous debate among criminal law scholars about whether the pathologies of policing are better addressed through increasing democratic control or by increased reliance on bureaucratic expertise ${ }^{453}$ Yet even the proponents of expert policing seek to make police forces function more like administrative agencies in a wellfunctioning democracy. ${ }^{454}$ And in administrative law, an agency's lack of direct electoral accountability is justified by other mechanisms of political oversight combined with public participation in the regulatory process. ${ }^{455}$ By contrast, law enforcement exceptionalism insulates police from the oversight of elected leaders and the participation of the public. Even the bureaucratic expertise model of policing reform requires more democratic accountability than law enforcement exceptionalism permits.

Law enforcement exceptionalism thus renders police agencies illegitimate under a wide range of democratic theories. Proponents of participatory $^{456}$ and deliberative ${ }^{457}$ theories of democracy hold that institutions of

Columbia Law Review) (reporting that seventy-three percent to eighty-three percent of drivers self-report recent speeding, depending on the type of road).

452. See supra note 18 and accompanying text.

453. Compare, e.g., Kleinfeld et al., supra note 105, at 1699-700 (arguing that civilian review boards "should disseminate ... information and advice to the local community whenever possible[,] . . taking into account goals of transparency, legitimacy, and ultimate democratic control”), and Simonson, Power Lens, supra note 14, at 787-92 (advocating for reforms that focus "on governance and policymaking arrangements rather than outcomes or policies themselves"), with Rachel Elise Barkow, Prisoners of Politics: Breaking the Cycle of Mass Incarceration 165-85 (2019) ("We need to establish expert agencies charged with instituting and evaluating criminal justice policies so that we get better outcomes ...."), and Rappaport, supra note 82, at 716-21 ("When all the evidence is fairly weighed, the argument for more participatory democracy becomes significantly harder to sustain, at least if the goal is a better criminal justice system rather than participation for its own sake."). For a recent overview of the current debate between "democratizing" and "bureaucratizing" solutions to criminal law, see generally Benjamin Levin, De-Democratizing Criminal Law, 39 Crim. Just. Ethics 74 (2020) (reviewing Barkow, supra).

454. See Barkow, supra note 453, at 165-85; Rappaport, supra note 82, at 811-13.

455. See Gillian E. Metzger, Administrative Constitutionalism, 91 Tex. L. Rev. 1897, 1901 (2013). For a proposal to use state administrative law to require such oversight, see Christopher Slobogin, supra note 31, at 134-149.

456. See generally Jane J. Mansbridge, Beyond Adversary Democracy (1983) (investigating and describing participatory democracy); James Miller, Democracy Is in the Streets: From Port Huron to the Siege of Chicago (1994) (discussing participatory democracy in the context of the New Left movement of the late 1960s).

457. See generally James S. Fishkin, Democracy and Deliberation: New Directions for Democratic Reform 12 (1991) (arguing for deliberative innovations in the American political process, "where the people could exercise their power more thoughtfully"); Amy Gutmann \& Dennis Thompson, Why Deliberative Democracy? 7 (2004) (“[W]e can define deliberative democracy as a form of government in which free and equal citizens (and their representatives) ... justify decisions in a process in which they give another reasons that are 
governance, including police agencies, cannot be insulated from citizen control. Under these theories, democracy requires more of governance institutions than expert identification of and service to the interests of the governed. ${ }^{458}$ Rather, democracy requires the collective choice of collective action in pursuit of common interests, defined by the governed, through participation or deliberation. Insofar as decisions about collective action are delegated to representatives, those representatives must be accountable to the governed. This, in turn, requires that the governed be able to observe the decisions of the institutions governing them and either check or sanction those decisions. ${ }^{459}$ As currently constituted, police agencies are insulated from any such accountability. Thus, law enforcement exceptionalism is not only a barrier to solving the problems of discriminatory and violent policing - it is the source of an additional problem with policing: a deficit of democracy.

\section{B. The Cause: Locking in Reform}

Although law enforcement exceptionalism is a barrier to current reform, it is largely the creation of earlier reforms. Past reforms were encoded into law at state, local, and municipal levels. ${ }^{400}$ These efforts to structurally entrench policy gains helped to create the labyrinthine institutional structure that constitutes law enforcement exceptionalism.

Neither the police nor sheriffs were originally created to operate independently. For example, the leadership of police departments was

mutually acceptable and generally accessible . . . ."); Held, supra note 14, at 231-55 ("Deliberative democrats put a premium on refined and reflective [political] preferences."); Joshua Cohen, Deliberation and Democratic Legitimacy, in Deliberative Democracy: Essays on Reason and Politics 67, 67 (James Bohman \& William Rehg eds., 1997) (discussing "an account of deliberative democracy in terms of the notion of an ideal deliberative procedure").

458. Cf. Held, supra note 14, at 134-84 (summarizing, distinguishing, and critiquing "competitive-elitist" and "pluralist" theories of democracy); James Q. Wilson, Varieties of Police Behavior: The Management of Law and Order in Eight Communities 278-99 (1968) (studying patterns of, and constraints, on police discretion, exemplifying the pluralist tradition); Sklansky, Police and Democracy, supra note 131, at 1754-56 (describing how pluralist theories of democracy conceive of police agencies). Law enforcement exceptionalism is arguably compatible with a narrow pluralist theory of democracy under which democratic legitimacy requires only competition among interest groups regarding a narrow range of distributive questions, while elites are left unmolested to define and pursue the public interest. See Sklansky, Police and Democracy, supra note 131, at 1736-41 (noting that while Progressive Era reformers relied on expert oversight of police, postwar pluralists preferred to substitute judicial oversight-but both feared that democratic supervision would yield partisan policing). Following participatory and deliberative theorists, this Essay rejects the narrow view, and holds that democratic legitimacy requires political choice by the governed.

459. Arnold S. Kaufman, The Radical Liberal: New Man in American Politics 58-60 (1968) (arguing that both pluralist and participatory democracy require "subjection of leadership to the will of the people" because unaccountable leaders are not likely to satisfy popular preferences); Manin et al., supra note 14, at 4.

460. See supra sections II.A.2, II.B.2. 
chosen by the mayor, while elected council members also controlled the nomination of police officers and the priorities in their specific districts. ${ }^{461}$ Sheriffs always had a degree of independence, but they were not initially defined by their law enforcement responsibilities. ${ }^{462}$

Our current structural entrenchment reflects past efforts to reform this state of affairs, motivated by partisan conflicts. In this reform environment, success was not only measured by the ability to effectuate a particular vision of policing. It also meant codifying one's gains in ways that made them harder to unravel. Thus, to limit local opposition in the future, reformers turned to the state. ${ }^{463}$ To compensate for the possibility that future state legislatures might waver, constitutional amendments were pursued. ${ }^{464}$ Through a series of such steps, reformers created local law enforcement agencies that were increasingly resistant to subsequent reforms.

This strategy of structurally entrenching reform was, like overfishing a pond or overgrazing a commons, individually rational but collectively self-defeating. One majority could lock in its gains but only at the expense of future majorities denied the same opportunity. Earlier reformers used structural entrenchment to secure their gains because their battles over law enforcement reform were often fought along partisan, ethnic, and racial lines. ${ }^{465}$ These reformers understood that substantive debates over which kinds of institutional reforms to implement-state versus local control, the degree of political accountability, etc.-were not truly based on neutral principles of institutional design. Rather, reformers understood that the institutional structures of police agencies would affect whose interests they would serve. ${ }^{466}$ For big cities at the turn of the twentieth century, local political control of policing meant an immigrant-dominated police force sympathetic to the lifestyles and "vices" of their immigrantheavy precincts. ${ }^{467}$ State control over the selection of police officers, severing the link between police departments and ward leaders, promised staffing by native officers. ${ }^{468}$ The goal then was not simply to set in place substantive reforms but to do so in order to disempower rival ethnic and partisan constituencies.

The result is our current structure of local law enforcement: inflexible, entrenched, and resistant to political challenge. The lesson of

461. See Fogelson, supra note 256, at 24-25.

462. See supra notes 324-330.

463. See Richardson, supra note 231, at 46 ("The struggle for domination of the police took place . . . between the urban majorities and the state legislature. Those groups outvoted in a city could look to the state capital for relief, relief which was often granted because the interests of the urban and the state majority conflicted.").

464. See, e.g., Fogelson, supra note 256, at 289, 308.

465. See, e.g., Richardson, supra note 231, at 41.

466. See id. at 45-46.

467. See, e.g., Fogelson, supra note 256, at 47, 91-92, 129-30.

468. See id. at 90-92, 249-250. 
this history is not that radical reform should be avoided. Rather, it is that the institutional strategy for implementing reform is no less important than the substance of the reform. A strategy of structural entrenchment may calcify a set of institutional arrangements that are politically liberating in the short run, but oppressive in the long run. ${ }^{469}$ Unintended consequences or unanticipated problems will arise. Circumstances will change. Different priorities and needs will emerge.

Our strategies for challenging police power must be attentive to these possibilities. The question then is not just what kind of reforms we implement today but whether the reforms put into place today will leave room for future generations to do the same. Radical as it may seem to disband police forces, replacing them with other law enforcement agencies falls short of the abolitionist vision of peacefully cultivating public safety without reliance on coercion and punishment. Locking in any currently feasible replacement deprives future democratic majorities of any opportunity to pursue further steps toward that more radical vision. Structural flexibility thus ensures that achievable short-term reforms do not become tools for preempting more ambitious ones.

\section{A Lesson: Simplifying Police Governance}

Bleak as it is, our account of law enforcement exceptionalism points toward a new strategy for attacking the pathologies of policing. To change policing, it may be necessary to make its legal structure more dynamic, and thereby also facilitate future change. One way to do so is to vest authority over the institutional structure of law enforcement in one representative body of government of general jurisdiction. This strategy is one of reasserting democratic control by clearly identifying decisionmakers responsible for overseeing and, when necessary, changing law enforcement performance. Vesting control of law enforcement in a government of general jurisdiction ensures that law enforcement will have to compete for resources with other priorities. Simplifying police governance is designed to target the two most troubling consequences of law enforcement exceptionalism.

First, it will increase the transparency of police governance by restructuring police agencies so the public can recognize who has authority over them. Locating the power to disband or reform a department at one level of government enables the public to understand who has power to effect change. Through the amendment of state constitutions-a more realistic

469. Cf. Michael C. Dorf \& Charles F. Sabel, A Constitution of Democratic Experimentalism, 98 Colum. L. Rev. 267, 315 (1998) (“[E]ffective government services and regulations must be continuously adapted and recombined to respond to diverse and changing local conditions, where local may mean municipal, county, state, or regional as the problem requires."). 
endeavor than amending the U.S. Constitution ${ }^{470}$-policymakers can create or clarify the authority of an elected body to disband a police agency. A clearly identified elected body, with the power to destroy a police agency, will clarify for the public who has the power to control and transform that agency.

Second, vesting policing authority in one level of government will eliminate veto points that police agencies leverage to guard their power. ${ }^{471}$ At present, a successful campaign to disband a police agency might require activists to overcome veto points across local, county, and state governments. Cities seeking to restructure their police departments need to contend with the limitations of state law, and whether those laws prevent them from disbanding police departments or limit the kinds of reforms they may put into place. They may also have to contend with the possibility of state preemption, and the prospect of increased law enforcement activity by county sheriffs' offices in their jurisdiction. If cities were free of these limitations, police departments could no longer rely upon state legislatures to protect them from local political pressure. Conversely, if state governments were to assert full control over local policing, activists could direct their energy toward state legislatures without fearing that police departments would block reform at the municipal level. Our normative preference, as we argue below, is for local control over police agencies. ${ }^{472}$ More important, however, is that there be only one level of elected government mediating between police agencies and the public will.

Simplifying police governance is strategically necessary for those who wish to transform policing, but normatively desirable for all. At the strategic level, unless the new institutions are easily altered, they will ultimately entrench and empower police again. At the normative level, policymakers can strengthen the political legitimacy of policing by strengthening democratic control over law enforcement agencies. Under law enforcement exceptionalism, the locus of political contestation is at the agenda-setting stage-where police bureaucracies have a strategic and informational advantage over informal citizen groups. ${ }^{473}$

This consolidation of democratic levers changes the locus of political contestation from this agenda-setting stage to that of substantive deliberation. Such a change will likely redound to the benefit of citizens and weaken entrenched actors' stranglehold over the agenda-setting process. By locating power at one level of government, simplifying police governance empowers citizen groups that are currently unable to participate in

470. See James A. Gardner, Devolution and the Paradox of Democratic Unresponsiveness, 40 S. Tex. L. Rev. 759, 762 (1999).

471. Given the separation of powers at the state and local levels and the bicameral nature of most state legislatures, our solution will not eliminate every veto point that police departments can leverage.

472. See infra section III.D.

473. See Miller, Perils, supra note 443 , at $167-74$. 
the complex, multilevel political process that shapes law enforcement policy. ${ }^{474}$ Eliminating veto points should better enable elected officials to deliver the results their constituents demand. ${ }^{475}$ The increased efficacy of such demands should incentivize citizens to mobilize. Simplifying police governance thus would create a structure that would render police accountable to an elected decisionmaker and, thereby, to the people.

Greater flexibility is also necessary in anticipation of reform efforts yet to come. The importance of promoting structural flexibility is also to pave a path for future generations of reformers. We should hope but not presume that any reform that is put into place today will stand the test of time. We should also recognize that law enforcement structure might need to be tailored continuously to accommodate local conditions and changing circumstances. ${ }^{476}$ More importantly, structural flexibility is important in order to ensure that debates and discussions about law enforcement reforms are robust and worthwhile. Countless conversations about reforms have been unduly limited or prematurely cut off when confronted with the legal entrenchment of the existing law enforcement structure. Promoting structural flexibility will ensure not only that the current political conversation continue but also that future conversations can take place.

\section{The Structural Case for Local Control}

The principal lesson of our analysis is that police agencies should be restructured not only to expose the pathologies of policing to democratic reform but also to end law enforcement exceptionalism. Any reform adequate to address the pathologies of policing - whether disbanding, defunding, or disaggregating the policing function-should be pursued in tandem with reforms to the political organization of policing. Those reforms should vest control over the institutional form of policing and the practice of policing at one level of government. Moreover, the electorate of that government should be geographically congruent to the territorial jurisdiction of the police-thus ensuring conformity to the democratic principle that decisions should be made by those most affected thereby. That principle, in turn, achieves both the normative goal of freeing policed communities from illegitimate governance and the strategic goal of controlling police conduct.

The question remains as to where that authority should be placed. Our answer is that the power to disband and otherwise transform the police should be vested in local governments, whether cities or counties.

474. See id.

475. Cf. id. at 174 ("[F] ederalism exacerbates the classic collective action problem by increasing the number of potential veto points for single-minded, narrow interests and by isolating potential allies from one another.").

476. See Dorf \& Sabel, supra note 469, at 315. 
Here we set out the case for local control and outline how it could be achieved as a matter of law.

We recognize at the outset that expanding structural flexibility does not require entrusting authority to local governments. Some might believe that because the police power is ultimately held by the several states, authority over law enforcement structures should also be centralized in the state. ${ }^{477}$ But we believe this would disempower geographically concentrated communities of color. Others might believe that the problems with law enforcement in America is that it is too decentralized and subject to local discretion, and thus we should follow other countries in creating a national police force and centralizing authority over law enforcement structure in the federal government. But we believe the problems of discriminatory and violent policing are not confined to any region and have been exacerbated by federal decisionmaking. Regardless, one can agree that structural entrenchment is a problem and still disagree that the organization of local law enforcement should be a matter of local control. Nevertheless, we believe there are many good reasons to favor cities and counties over the state and federal governments.

First, for path-dependent reasons, locating all authority at the local level is the shortest route to simplifying and democratizing policing. That arrangement comports with the currently decentralized nature of law enforcement jurisdiction. Police departments and sheriffs' offices, currently the primary agencies of law enforcement, have local jurisdictions and are funded primarily from local coffers. They work with county prosecutors, appear as witnesses in county and local courts, and-although perhaps unfortunately ${ }^{478}$-enforce local ordinances.

Second, cities and counties are "general-purpose" governments. Law enforcement should be assessed and funded in competition and coordination with all the other services that local governments provide. Policing is only one interest local governments serve, and general-purpose local governments are in the best position to see how it fits with those other interests. It is also through local governments that residents can most directly participate in balancing those interests and deciding whether police or other public service agencies are in the best position to serve them.

Third, local control allows for the flexibility and policy variability necessary for governing under conditions of uncertainty. ${ }^{479}$ The enforcement even of state laws should be tailored to local context. This is especially true when the benefits of enforcement are weighed against the costs. Certain communities may decide that low-level drug offenses are not as important

477. See, e.g., Ponomarenko, supra note 193, at 59-63 (arguing for state-level legislative and administrative regulation concerning "police policies, training requirements, data collection, and monitoring").

478. See Brenner Fissell, Local Offenses, 89 Fordham L. Rev. 837, 840-45 (2020) (observing that local offenses are often deficient in legality and culpability).

479. See Dorf \& Sabel, supra note 469, at 315. 
as violent crimes and redirect their resources accordingly. Moreover, given that many of the concerns with policing involve the activities of officers on the street-far from the notice of elected officials at the state and national levels-it is often the local residents themselves that are in the best position to assess the nature and impact of those activities. This local knowledge is a necessary tool of effective governance under such conditions. ${ }^{480}$ Moreover, in most states, prohibitions on special legislation restrict the ability of state legislatures to tailor the design of institutions to local circumstances-which would likely lead to a dangerous delegation of decisionmaking discretion to police officials.

Fourth, local control is the best way to ensure political accountability and legitimacy. Local control is especially important given the disproportionate impact of policing on poor and minority neighborhoods. Control at the state or national level might better ensure uniform standards. But the minority groups most severely impacted by policing often have little influence at those levels. ${ }^{481}$ And while local representation is a concern in many local jurisdictions, Blacks and other minorities tend to succeed more often in influencing local politics. ${ }^{482}$ After all, this was why the states so quickly became involved in regulating police departments after their creation at the local level: They believed police were too beholden to the urban immigrants that had seized political control of the cities. And the groups that suffered the most from the expansion of state control were the Black and Latinx residents who achieved local political power only after those reforms. ${ }^{483}$ Local control would ensure that local law enforcement agencies are accountable to the residents over which they exercise power. At the same time, local democratic control would not preclude civil rights enforcement efforts by the Department of Justice, ${ }^{484}$ or by state attorneys general. ${ }^{485}$ More ambitiously, local control could allow for experimentation with institutional mechanisms that shift law enforcement decisionmaking power to those who are most affected by aggressive policing. ${ }^{486}$ In sum, local control confers political legitimacy by ensuring that "those who bear the costs of crime and punishment alike . . . exercise more power over those who enforce the law and dole out punishment." ${ }^{487}$

480. See id.

481. See Miller, Perils, supra note 443 , at 7 .

482. Id. at 170-74 (concluding that citizen groups comprised of poor people and minorities are more engaged in crime control politics at the local level than at the state or federal levels).

483. See supra note 256 and accompanying text; supra Part I.

484. See supra notes 85-94 and accompanying text.

485. See generally Mazzone \& Rushin, supra note 87 (advocating for such reforms). Indeed, simplifying police governance at any level might ease such enforcement efforts by rendering police practices more transparent and fixing responsibility in one decisionmaker.

486. See Simonson, Power Lens, supra note 14, at 782-92.

487. See Stuntz, Collapse of American Criminal Justice, supra note 103, at 7. 
Local control does not, however, require state and federal governments to abnegate oversight over local policing. Rather, local control would require that local elected officials have (1) the primary political responsibility to oversee police agencies and (2) the legal authority to organize, restructure, and reconstitute those agencies when necessary. It would be consistent with this allocation of political authority for the federal government to continue in its efforts (however modest) to pursue consent decrees against local police departments that engage in civil rights violations. Likewise, local control is compatible with reforms that enable state attorneys general to obtain consent decrees through litigation. Such federal and state oversight is consistent with a regime of simplified police governance as long as local officials retain ultimate legal authority to oversee and restructure local police departments.

Given the desirability of local control, it is worth mapping the steps required to vest policing authority exclusively in these jurisdictions. For police departments, this entails reforming state and local laws to make them function as subordinate municipal departments. The first step might be for cities to amend their municipal charters to permit disbanding of police departments to take place, and to entrust that power to the city council going forward. The role of state law will also need to be reconsidered. In some states, state laws may need to be repealed or amended to restore local control over police departments. In others, a similar result might also be achieved if existing structural home-rule protections are interpreted by courts to limit state interference with the organization and operation of municipal departments. The Ohio Supreme Court, for example, has struck down state laws regulating the selection of police chiefs ${ }^{488}$ and the organization of municipal police departments ${ }^{489}$ as violations of municipal home-rule powers over "local self-government." It is possible that similar arguments can succeed in other states.

Reforms to the legal structure of sheriffs are more difficult, but perhaps even more important. Home rule might also prove to be a convenient path to bring sheriffs' offices under county control. When Miami-Dade County abolished the office of the sheriff in the 1950s, it was due to a state constitutional amendment granting counties home-rule powers over their own governmental structure and other county offices that serve in their jurisdiction. Even counties that did not go this route used county home rule to assert greater control over sheriffs. To be sure, Florida has rolled back these reforms through a subsequent constitutional amendment. Yet the expansion of county home rule in the 1950s might be

488. See State ex rel. Lynch v. City of Cleveland, 132 N.E.2d 118, 121 (Ohio 1956) (holding that a city is not subject to state law in how it selects its police chief).

489. See Harsney v. Allen, 113 N.E.2d 86, 88 (Ohio 1953) ("The organization and regulation of its police force, as well as its civil service functions, are within a municipality's powers of local self-government."). 
a model that could be adopted in other states and eventually restored in Florida.

The concurrent jurisdiction of police departments and county sheriffs also should be eliminated. Cities where a police department has been established should be excluded from the jurisdiction of county sheriffs unless assistance is requested by an elected body. At the same time, the ability to contract with sheriffs should be retained. Thus, cities without police departments-either as a result of disbanding or because one was never created-could still choose to contract with the sheriff for policing services. But eliminating concurrent jurisdiction over policing will give cities more control over law enforcement encounters on their streets.

In short, there are good reasons to simplify and democratize the governance of law enforcement by placing decisions about its structure as well as its operations under the control of elected, general-purpose, local governments.

\section{CONCLUSION}

Policing in America is afflicted by pathologies that incremental reforms are unlikely to solve, both because of the scope of such reforms and the structural obstacles to their implementation. Given this troubling state of affairs, localities may better address the pathologies of policing by disbanding and replacing police departments and sheriffs' offices. Yet any effort to disband law enforcement agencies will have to address their structural entrenchment.

All of this implies that contemporary efforts to reimagine policing should also seek to reimagine the legal structure of local law enforcement agencies. The law enforcement exceptionalism that now differentiates police departments and sheriffs' offices from other organs of local government should be dismantled. The structural authority of general-purpose local governments over these "local" agencies should be expanded to ensure that law enforcers are democratically accountable to the residents they are sworn to serve and protect.

Reformers should sometimes work to disband police agencies, but in doing so should resist the temptation to entrench new institutions of local government. Ambitious as disbanding and replacing may seem, it falls far short of the abolitionist aspiration to achieve public safety by entirely peaceful and cooperative means. In subjecting policing to popular rule, we need not preclude the people from someday deciding to abolish it entirely. 